The political economy of statutory reach: U.S. disclosure rules in a globalizing market for se Fox, Merritt B Michigan Law Review; Dec 1998; 97, 3; ProQuest pg. 696

\title{
THE POLITICAL ECONOMY OF STATUTORY REACH: U.S. DISCLOSURE RULES IN A GLOBALIZING MARKET FOR SECURITIES
}

\author{
Merritt B. Fox* \\ TABle of CONTENTS \\ I. The Current U.S. Approach to Statutory \\ REACH ................................... 705 \\ A. Issuer Disclosure Triggered by Primary Market

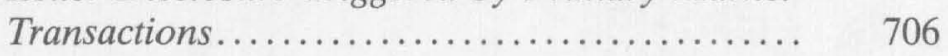 \\ 1. The SEC's Traditional Approach.......... 706 \\ 2. Regulation $S \ldots \ldots \ldots \ldots \ldots \ldots \ldots \ldots \ldots \ldots . \ldots \ldots$ \\ B. Issuer Disclosure Triggered by Secondary
Market Transactions ..................... 712 \\ 1. Foreign Issuers ......................... 712 \\ 2. U.S. Issuers ........................... 714 \\ C. Conclusion ............................ 717 \\ II. Legal Constraints on the SEC, the Courts, \\ AND Congress in Deciding IsSues of \\ Statutory ReACH....................... 717

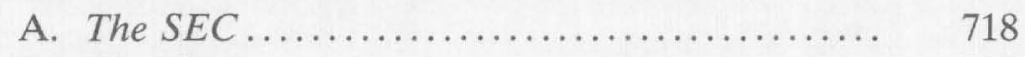 \\ B. The Courts ......................... 721 \\ C. Congress and Its Constraints Under \\ 1. Bases for Prima Facie Jurisdiction to
Prescribe ........................... 724 \\ 2. Limitations on Actual Jurisdiction to \\ Prescribe: Considering the Intensity of U.S. \\ Interest and That of Other Countries....... \\ * Professor of Law, University of Michigan. B.A. 1968, J.D. 1971. Ph.D. (Economics) \\ 1980. Yale. - Ed. The author wishes to express his appreciation for helpful comments on \\ earlier drafts of this article to Professors Richard Friedman. Avery Katz. Larry Kramer, Saul \\ Levmore, Kyle Logue, Roberta Romano, and Lynn Stout. Dean Joel Seligman and partici- \\ pants at the Brooklyn Law School Workshop on International Business. the Columbia Uni- \\ versity Law and Economics Workshop, the University of Michigan Law and Economies \\ Workshop, the Georgetown University Conference on the Regulation of International Activ- \\ ity, and the 1997 American Law and Economics Association Annual Meeting. Financial sup- \\ port for this project was provided by the Cook Fund of the University of Michigan.
}

696 
III. The Superiority of the Issuer Nationality APPROACH OVER THE INVESTOR RESIDENCY

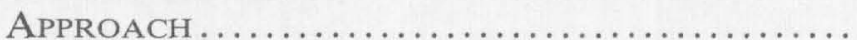

A. The United States Has a Strong Interest in Determining the Disclosure Behavior of U.S. Issuers Even When Their Shares Are Publicly Sold to and Traded Among Only Foreign Investors ..............................

1. The Basis of the U.S. Interest ............ 732

2. Foreign Relations ..................... 735

B. The U.S. Has, at Best, Only a Weak Interest in Determining the Disclosure Behavior of Foreign Issuers Even When Their Shares Are Publicly Sold to or Traded Among U.S. Investors ........ 1. The Basis of the Interest ................ 736

2. Countervailing Domestic Considerations ... 737

3. Foreign Relations .................... 738

4. Qualifications for IPOs and Foreign Issuers Trading in Immature Markets ..............

C. The Analysis of U.S. Interests Does Not Depend on Other Countries Also Adopting the Issuer Nationality Approach .................

1. Why There Is No Need for the Foreign Issuer's Home Country to Switch ..........

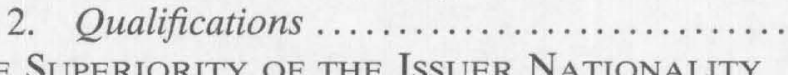

IV. The Superiority of the Issuer Nationality over the Transaction Location Approach...

A. The Transaction Location Approach Gives U.S. Issuers Increasing Freedom to Choose Which Country's Regime Governs Them and Their Preference Is for a Regime Requiring Less Disclosure Than Is Socially Optimal ..........

1. The Issuer's Increasing Freedom to Choose Its Disclosure Regime ...................

2. Market Failure: The Issuer's Preference for a Socially Suboptimal Disclosure Regime..

3. Conclusion ........................ 753

B. The Transaction Location Will Reduce the Volume of Share Transactions Effected in the United States ..............................

1. The Transaction Location Approach Will 754 Discourage Issuers With Privately Optimal 
Disclosure Levels Below What Is Required by the U.S. Regime from Entering the U.S. Market .................................

2. Issuers Having Privately Optimal Disclosure Levels at or Above What Is Required by the U.S. Regime Will Not Be Attracted to the U.S. Market by the Transaction Location Approach .............................

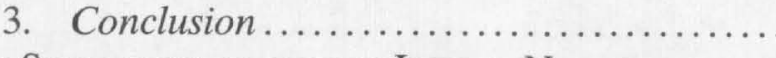

V. The Superiority of the Issuer Nationality Approach over Any Achievable

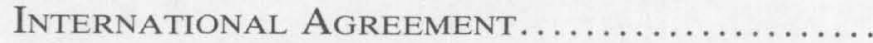

A. National Differences in Issuer Decision Structures .............................

B. National Practice Reflects Resulting Differences in Optimal Disclosure Levels.................

C. Implications for the Likelihood of an International Regime ........................

1. Administrative Convenience ................ 760

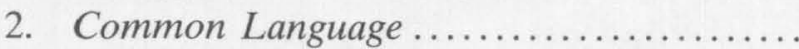

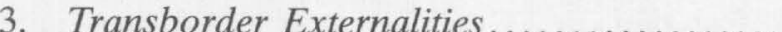

VI. How Globalization Increases Political Pressure to Lower U.S. Disclosure STANDARDS UNDER THE INVESTOR RESIDENCY and Location of Trade Approaches but Not UNDER THE IsSUER NATIONALity APPROACH.....

A. The Issuer Nationality Approach ............ 768

B. The Investor Residency and Transaction

Location Approaches

1. General Considerations ................. 768

2. The Impact of the Global Diffusion of

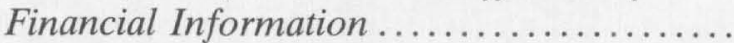

3. Reductions in the Cost and Difficulty of Effecting Transactions Abroad .............

VII. How the Increasing Pressures Únder the InVESTOR RESIDENCY AND LOCATION OF Trade APPROACHES TO LOWER THE LEVEL OF U.S. Required Disclosure Can Lead to

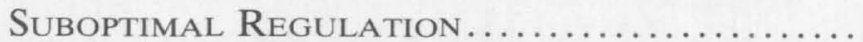

A. How Increased Pressure to Lower U.S.

Disclosure Standards May Succeed Even If It Lowers National Welfare ..................... 
1. The Quest for Rents and the Adoption of an Inefficiently Low Required Disclosure Level. .

2. The Race to the Bottom

B. The Appropriateness of Assuming Current U.S.

Disclosure Standards Are Optimal and the

Question of Regulatory Competition ...........

1. A Preliminary Consideration ................

2. The Starting Presumption: For Regulating Each State's Entirely Domestic Activities, Its Rules Are Superior to Those of Any Other

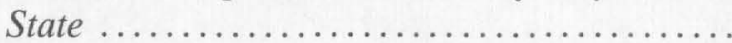

3. The Public Choice Critique in the Purely Domestic Context .......................

4. Even If the Public Choice Critique Is Valid in the Purely Domestic Context, Regulatory Competition Is Not Necessarily a Helpful Antidote .............................

5. Public Choice Arguments for Not Promoting Regulatory Competition

6. Regulatory Competition and Differences Among U.S. Issuers in Their Socially Optimal Disclosure Levels

7. Summary ............................ 795

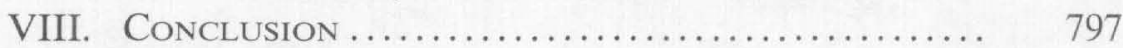

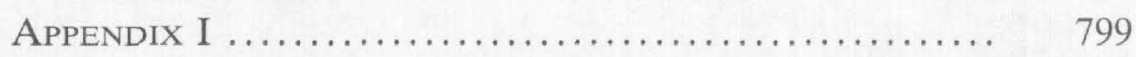

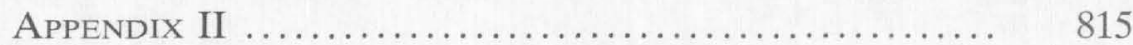

This Article addresses the appropriate reach of the U.S. mandatory securities disclosure regime. While disclosure obligations are imposed on issuers, they are triggered by transactions: the public offering of, or public trading in, the issuers shares. Share transactions are taking on an increasingly transnational character. The barriers to a truly global market for equities continue to lessen: financial information is becoming increasingly globalized and it is becoming increasingly inexpensive and easy to effect share transactions abroad.' There are

1. For a detailed discussion of the trend toward a global market for the securities of significant issuers, see Merritt B. Fox, Securities Disclosure in a Globalizing Market: Who Should Regulate Whom, 95 Mich. L. Rev. 2498 (1997) [hereinafter Fox. Disclosure in a Globalizing Market]. 
approximately $41,000^{2}$ issuers of publicly traded shares in the world. For an ever larger portion of these issuers, there will be significant numbers of transactions in their shares that have at least one U.S. dimension - the investor will be a U.S. resident, the transaction will occur in the United States, or the issuer itself will be from the United States - thereby generating some kind of claim for the United States to apply its disclosure regime. On which of these issuers is it in fact in the enlightened best interest of the United States to do so?

In a previous article in this Review, I addressed the question of what apportionment of regulatory authority among the countries of the world would most enhance global economic welfare. ${ }^{3}$ The concern here is with the practical choices faced by U.S. officials as to the reach of their particular country's regime. Building on the earlier article, this piece thus extends the inquiry by examining the legal and political environment in which these officials operate and the impact of their decisions on U.S. economic welfare. ${ }^{4}$

The Securities and Exchange Commission ("SEC") has traditionally taken the position that the reach of the U.S. disclosure regime should be set so as to protect U.S. resident investors from making damaging securities choices due to poor information. ${ }^{5}$ This has been the position of most academic commentators as well. ${ }^{6}$ The goal of "investor protection" leads directly to the principle that the only transactions associated with an issuer that should trigger

2. According to the International Finance Corporation's annual survey of world stock exchanges, the total number of listed domestic companies worldwide in 1995 was 36,572 . See International Fin. Corp., Emerging Stock Markets Factbook 1998, at 23 (1998).

3. See Fox, Disclosure in a Globalizing Market, supra note 1.

4. This Article's focus on U.S. economic welfare does not mean that I believe as a general matter that U.S. practices with effects abroad should be judged solely by their impact on the United States. Rather, it reflects the fact that the U.S. officials making decisions concerning the reach of the U.S. regime will be primarily concerned with U.S., not global, welfare. It also reflects the fact that the impact of their choices on U.S. welfare is an important component in determining the legal constraints under which these officials operate. See infra Part II. In any event, as it turns out, there is no real conflict here. A comparison of the recommendations of this and the earlier article shows that the U.S. approach to statutory reach that most enhances U.S. welfare most enhances global welfare as well. And this is true whether or not other countries adopt similar practices.

5. See infra section I.A.1.

6. See, e.g., James J. Fanto, The Absence of Cross-Cultural Communication: SEC Mandatory Disclosure and Foreign Corporate Governance, 17 Nw. J. INTL. L. \& Bus. 119 (1996); J. William Hicks, Protection of Individual Investors Under U.S. Securities Laws: The Impact of International Regulatory Competition, 1 Ind. J. OF Global Legal Stud. 431 (1994). Richard Breeden, a former Chairman of the SEC, takes a similar position. See Richard C. Breeden, Foreign Companies and U.S. Securities Markets in a Time of Economic Transformation, 17 FordHAM INTL. L.J. 77, 90 (1994) (symposium). 
imposition of U.S. disclosure regulation are those involving U.S. investors. ${ }^{7}$

In 1988, the SEC, in proposing its subsequently adopted Regulation S, articulated a different, capital market protection goal for the U.S. approach to statutory reach. ${ }^{8}$ The new goal still seeks to protect certain investors from being poorly informed, but reformulates the class of persons protected to include all investors, wherever resident, but only if they purchase in the U.S. market. This change in articulated goal suggests that the place where transactions in an issuer's shares occur should be the exclusive consideration in deciding whether to apply the U.S. regime. The United States should impose its regime on all issuers where a significant number of transactions in their shares are effected in the United States and on no other issuers. The nationality of the issuer and that of the buyers of its shares should be irrelevant. ${ }^{9}$

A third possible goal for the U.S. approach to statutory reach would be to maximize, to the extent cost effective, the benefits enjoyed by U.S. residents from disclosure's capital allocation improvement and managerial agency cost reduction effects. ${ }^{10}$ The

7. In actual practice, the United States puts some weight as well on the nationality of the issuer and the location of the potentially triggering transactions. See infra Part I. Inclusion of these additional factors, however, is presumably justified by the idea that they serve as proxies for the nationality of buyers, information about which is hard to acquire. The fact that transactions in an issuer's shares occur in the United States or that the issuer is from the United States increases the likelihood that the buyers are in fact U.S. residents.

8. See Securities Act Release No. 6779, 41 SEC Docket (CCH), at 126. 132 (June 10. 1988) [hereinafter Initial Proposing Release]; infra section I.A.2.

9. Transaction location has always played a role in determining the reach of the regime. See infra sections I.A.1 and I.B. While the SEC has not yet moved actual U.S. practice significantly toward exclusive reliance on this approach, see infra sections I.A.2. I.B.1, I.C. the mere articulation of the capital market protection goal puts such exclusive reliance on the agenda for discussion and raises the possibility the SEC will make this move in the future. Professors Stephen Choi and Andrew Guzman have, for example, recently endorsed just such exclusive reliance on the transaction location approach. See Stephen J. Choi \& Andrew T. Guzman, The Dangerous Extraterritoriality of American Securities Law, 17 Nw. J. INTL. L. \& Bus. 207, 221-23 (1996) [hereinafter Choi \& Guzman, Dangerous Extraterritoriality]; Stephen J. Choi \& Andrew T. Guzman, National Laws, Intemational Money: Regulation in a Global Capital Market, 65 Fordham L. Rev. 1855, 1894 (1997) [hereinafter Choi \& Guzman. National Laws].

10. There has been a growing recognition over the last fifteen years of the importance of economic efficiency as a goal for disclosure regulation. Professor Coffee, for example, states: "This focus on fairness, rather than efficiency, is not surprising because proponents of a mandatory disclosure system have historically stressed the former over the latter. Nonetheless, the strongest arguments for a mandatory disclosure system may be efficiencybased." John C. Coffee, Jr., Market Failure and the Economic Case for a Mandatory Disclosure System, 70 VA. L. Rev. 717, 751 (1984). See also Steven A. Ross, Disclosure Regulation in Financial Markets: Implications of Modern Finance Theory and Signaling Theory, in Issues in Financial Regulation 191 (Franklin Edwards ed., 1979). The growing importance of efficiency is also illustrated by the recent enactment of The National Securities Market Improvement Act of 1996, Pub. L. No. 104-290, 110 Stat. 3416 (to be 
concern under this goal is the capacity of issuer disclosure to aid in the functioning of the real economy in the United States, i.e., in the production of goods and services. This goal, we will see, implies that U.S. practice should be changed so that we impose the U.S. regime only on issuers of U.S. nationality, but do so wherever transactions in the issuer's shares are effected and whatever the nationality of the buyers. The nationality of an issuer would be determined by where the issuer has its center of gravity as a firm. ${ }^{11}$

I conclude that this third goal - capital allocation improvement and managerial agency cost reduction - is the only viable goal for disclosure regulation in a world with a global market for securities. I thus recommend that the reach of the U.S. disclosure regime be determined by the nationality of the issuer. ${ }^{12}$ I come to this conclusion by using the tools of financial economics to trace out the ultimate effects in different countries of the disclosure behavior of transnational issuers. The pattern of effects revealed by this exercise shows that the issuer nationality approach most enhances U.S. economic welfare. Because the adherents of the investor residency and transaction location approaches have not traced out the ultimate effects in this fashion, they have failed to appreciate the superiority of the issuer nationality approach. ${ }^{13}$

Two examples help show how this recommended change in approach would fundamentally alter current practices. The United

codified as amended in scattered sections of 15 U.S.C.). which amended the Securities Act of 1933 to add Section 2(b) providing that:

Whenever pursuant to this title the Commission is engaged in rulemaking and is required to consider or determine whether an action is necessary or appropriate in the public interest, the Commission shall also consider, in addition to the protection of investors, whether the action will promote efficiency, competition, and capital formation. 15 U.S.C.A. $\$ 77 \mathrm{~b}$ (b) (emphasis added). The 1996 Act made an essentially identical amendment to the Securities Exchange Act of 1934 by the addition of Section 3(f). See 15 U.S.C.A. $\$ 78 \mathrm{c}(\mathrm{f})$.

11. Important factors would include where the entrepreneurs who formed the enterprise reside. where the current headquarters is located, and where the bulk of its operations are now conducted. Nationality would not be determined by jurisdiction of incorporation or where the issuer's shareholders reside.

12. For a less theoretical article that takes a position close to the issuer nationality approach that I advocate here, see Edward F. Greene et al., Hegemony or Deference: U.S. Disclosure Requirements in the International Capital Markets, 50 Bus. LAw. 413 (1995). Some economists have favored such an approach also. See, e.g. Franklin R. Edwards, Listing Foreign Securities on U.S. Exchanges, 5 J. Applied Corp. Fin. 28 (1993).

13. See supra note 6 . These authors, of course, may have conceived of their projects as the development of principles of statutory reach within what they interpret as the bounds imposed by existing statutory language and judicial and administrative precedent. While I believe that the issuer nationality approach recommended here does fit within these bounds. particularly after the recent enactment of the National Securities Market Improvement Act of 1996 , see infra note 58 , I am, as noted, addressing a different question in this article, to wit: what approach to statutory reach will maximize U.S. economic welfare? The answer to this question is important whether or not its adoption would require legislative change. 
States, unlike today, would apply the mandatory disclosure requirements of the Securities Act of 1933 and the Securities Exchange Act of 1934 even to a U.S. corporation that goes public abroad through an offering in the Euroequity market and that imposes restrictions on the offering designed to deter its "flowback" into the United States. The United States, also unlike today, would not apply these requirements to an established French public issuer conducting a share offering in the United States to U.S. residents as long as the issuer provides, pursuant to the French regime, the same disclosure as it would have if it had made a purely domestic public offering in France.

One other alternative should be noted at the outset. If the U.S. disclosure regime were made voluntary, the problem of defining its reach would disappear. ${ }^{14}$ A few legal scholars, such as Professors Roberta Romano, Stephen Choi, and Andrew Guzman, suggest just such a change, in reaction, in part, to the increasing need to define the reach of the existing mandatory regime. Under their proposals, every issuer, whether U.S. or foreign, could choose whether to subject itself to the disclosure obligations of the U.S. regime or the regime of one of the fifty states or some other country. ${ }^{15}$ Whether it is desirable to make the U.S. regime voluntary, however, rests largely on considerations that are equally present with or without globalization. It is thus separate from the question addressed in this article: What is the appropriate reach of a mandatory disclosure system if we do have one? As a practical matter, since we are likely to continue to have a mandatory disclosure system for the

14. The underlying issues behind statutory reach do not entirely disappear, however. Elimination of U.S. mandatory disclosure statutes would represent U.S. policy that issuers should not be required to provide disclosure. U.S. officials and courts might still need to take a position as to which of the world's issuers this policy applies. The need to take such a position could arise as a result of a request made to such an official or court asking it to take some action that would assist in the enforcement of the disclosure regime of another country. Alternatively, it could arise from U.S. officials needing to decide whether affirmatively to take action to dissuade a foreign country from applying the foreign country's regime to a particular issuer or group of issuers.

15. See, e.g. Roberta Romano, Empowering Investors: A Market Approach to Securities Regulation, 107 YALE L.J. 2359 (1998). Professors Choi and Guzman also suggest such a reform, which they refer to as "portable reciprocity," as a more far reaching alternative to their proposed switch to exclusive reliance on the transaction location approach. See Stephen J. Choi \& Andrew T. Guzman, Portable Reciprocity: Rethinking the International Reach of Securities Regulation, S. CAL. L. Rev. (forthcoming 1998); see also Choi \& Guzman, Dangerous Extraterritoriality, supra note 9. at 231-32. I have written elsewhere an extensive critique of the scholarly principles for issuer choice. See Merritt B. Fox, Empowering Issuers to Choose Their Own Securities Regimes: A Mistaken Reform (Apr. 9, 1998) (unpublished paper presented at the University of Michigan Law and Economics Workshop, on file with author) [hereinafter Fox. Empowering Issuers]. 
foreseeable future, this question needs to be answered regardless of the other debate. ${ }^{16}$

This paper has seven Parts. Parts I and II look at the formal legal landscape. Part I reviews existing U.S. practice. Part II reviews the extent to which the SEC, the courts, and Congress are constrained by law in changing this existing practice and thus gives a sense of the scope of the reforms necessary to implement the change to the issuer nationality approach recommended here.

Parts III, IV, and V assess the effects on U.S. economic welfare of adopting the issuer nationality approach compared with adopting either of the other two approaches or a uniform international disclosure regime. Part III shows why the issuer nationality approach discriminates more precisely than the investor residency approach between those of the world's issuers whose disclosure behavior primarily affects the welfare of U.S. residents and those whose disclosure behavior primarily affects other countries. When a country's issuers disclose at an appropriate level, the disclosure can, through its positive effects on managerial motivation and the choice of real investment projects, increase the returns generated by capital-utilizing productive activity in that country. The beneficiaries of these increased returns are the country's entrepreneurial talent and labor, not the issuers' investors. Because of capital's greater mobility internationally, competitive forces push capital toward receiving a single global expected rate of return (adjusted for risk) regardless of the disclosure practices of the particular issuers involved. The United States thus has a strong interest in the disclosure behavior of all U.S. issuers, even those whose shares are sold to or traded among foreigners, but not in that of any foreign issuers, even those that are sold to or traded among U.S. residents.

Part IV shows that if issuers have a choice of disclosure regimes, they have a preference for picking one requiring less disclosure than is socially optimal. The transaction location approach gives issuers the capacity to determine which regime governs them. Thus it hurts U.S. economic welfare by permitting U.S. issuers to disclose at a lower than optimal level. It also reduces the volume of

16. This Article ultimately does touch upon issues that go to the desirability of a voluntary regime because the choice of approach to statutory reach determines whether regulatory competition will develop between the United States and other countries. Such competition is likely to lower U.S. requirements. One who believes that a mandatory U.S regime is undesirable, but who is faced with its continued existence. is thus likely to favor an approach to statutory reach that would promote such competition. These issues are explored infra in Parts VI and VII. 
transactions effected in the United States because the relative strictness of the U.S. regime scares issuers away. Part V shows why, in terms of U.S. welfare, the disclosure level required by any achievable uniform international regime would be inferior to that required by the U.S. regime.

Parts III-V assume that the choice of approach will not affect the level of disclosure required by the U.S. regime. Part VI relaxes this assumption. It shows that under the investor residency and transaction location approaches. the increasing globalization of the market for securities would lead to increased political pressures to lower the U.S. requirements, and that under the issuer nationality approach, it would not.

Part VII shows how these increased pressures are likely to result in the U.S. regime requiring too little disclosure. Some commentators believe that such regulatory competition would be helpful. Their arguments are found unpersuasive, however, in part because they do not account for the preference of issuers for disclosing too little. Thus the conclusion of Parts III-V that U.S. economic welfare would be enhanced by a switch to the issuer nationality approach is strengthened, not weakened, by the fact that such a switch would avoid these increased pressures to lower U.S. requirements that globalization would otherwise bring.

\section{The Current U.S. Approach to Statutory Reach}

Two basic components of U.S. securities law link transactions in securities with regulations requiring issuers to disclose information about themselves. First, certain sections of the Securities Act of 1933 (the "Securities Act") ${ }^{17}$ regulate the primary market for securities, imposing a set of disclosure obligations upon the offering and sale by the issuer of a new block of securities. Second, certain sections of the Securities Exchange Act of 1934 (the "Exchange Act" $)^{18}$ regulate the secondary market for securities. Exchange Act disclosure obligations are triggered by indices suggesting that already issued securities of an issuer will be frequently traded: a listing of the issuer's securities on a securities exchange or the existence of more than a given number of shareholders.

17. 15 U.S.C. $\$ 77 a-77 a a(1994)$.

18. 15 U.S.C. $\$ 78 \mathrm{a}-7811$. 


\section{A. Issuer Disclosure Triggered by Primary Market Transactions}

\section{The SEC's Traditional Approach}

Section 5 of the Securities Act by its terms prohibits the offer or sale of any security by any person unless the security is registered under the Act, ${ }^{19}$ which requires a complex process of disclosure. Section 5 makes no distinctions between foreign offerees and domestic ones, nor between transactions occurring abroad and transactions occurring at home. Its application depends only on the use at some point of an instrument of "interstate commerce" in connection with the transaction. ${ }^{20}$ Given the global interconnectedness of the financial industry today, use of such an instrument can be found in connection with almost every public offering in the world, wherever conducted and at whomever aimed. The question is whether Section 5 should be interpreted in some narrower fashion to limit its reach.

\section{a. A foreign issuer offering in the United States. While Section} 5 has not, in fact, been construed to cover all public offerings anywhere in the world by any issuer that uses an instrument of interstate commerce, the SEC has always interpreted Section 5 to cover public offerings in the United States by foreign issuers. ${ }^{21}$ The tradi-

19. Section 3 of the Act exempts certain securities from this requirement. Section 4 of the Act exempts certain transactions from this requirement including most secondary transactions.

20. Interstate commerce is broadly defined under Section 2(7) to include "trade or commerce in securities or any transportation or communication relating thereto among the several States... or between any foreign country and any State. ..." 15 U.S.C. $\$ 77 b(7)$.

21. Traditionally, foreign issuers wishing to publicly offer securities in the United States were required to register them on the same Form S-1 that was required of all domestic issuers not qualifying for one of the SEC's abridged forms. It was possible for potential issuers to obtain variations in the required accounting practices, but only through case by case negotiations with the SEC staff. See Harold Bloomenthal, 1980 Securities Handbook 354-57 (1980). In 1982, the SEC, in an extension of the integrated disclosure system, adopted three registration forms exclusively for foreign issuers: Forms F-1, F-2, and F-3. See Securities Act Release No. 6437, SEC Docket (CCH), at 964 (Nov. 19, 1982) [hereinafter Release No. 6437]. These new forms make a number of concessions to foreign issuers. They need not disclose as much information about their various lines of business, their management remuneration (which can be reported in aggregate rather than individually), and material transactions into which they have entered. They also may prepare their financial statements in accordance with home-country generally accepted accounting principles (GAAP) as long as they discuss material variances from U.S. GAAP and reconcile net income as determined under the two methods. See James A. Fanto \& Roberta S. Karmel, A Report on the Attitudes of Foreign Companies Regarding a U.S. Listing 9, 13 (NYSE Working Paper No. 97-101, 1997); Linda C. Quinn. Internationalization of the Securities Markets, in INternationalization of the Securities Markets: Business Experience and Regulatory Policy 1, 21-27 (A.L.I. ed.. 1991) [hereinafter Quinn, Business ExPerience].

In 1985 the Securities Exchange Commission issued a concept release entitled "Facilitation of Multi-National Securities Offerings" in which it first began to consider multijurisdictional disclosure, whereby a foreign issuer would be permitted to engage in a public 
tional position of the $\mathrm{SEC}$ has been that the registration requirements of Section 5 are primarily intended to protect United States investors, ${ }^{22}$ and a large portion of the purchasers of any public offering made in the United States would obviously be U.S. investors. The SEC's only concern has been - given the public interest in attracting foreign issuers to make public offerings in the United States market - how much, if any, it should relax the ordinary disclosure standards applicable to domestic issuers because of the special hardships these ordinary standards create for foreign issuers. ${ }^{23}$

b. A U.S. issuer offering abroad. The public offering abroad of newly issued securities by a United States issuer presents the converse of the transaction discussed above. The traditional investor protection rationale thus suggests that the United States disclosure regime should not be applied even if an instrumentality of interstate commerce has been used. This, in fact, has been the position of the SEC for over thirty years. Its policy has been not to take action against U.S. issuers for failure to register securities that have been distributed abroad to foreign nationals if the distribution is effected in a manner that will result in the securities coming to rest abroad. ${ }^{24}$

offering of its securities in the United States based on its home-country registration (with certain supplements, perhaps). See Securities Act Release No. 6568, 32 SEC Docket (CCH), at 707 (Feb. 28, 1985) [hereinafter Release No. 6568]; see also Linda C. Quinn, Internationalization of the Securities Markets, 743 PLI/CORP 17, 29 (1991) [hereinafter Quinn, Internationalization]. The release requested public comment on ways the SEC could facilitate multinational security offerings and streamline both the securities distribution systems and prospectus disclosure standards of the United States and other countries. See Release No. 6568 , supra. The SEC then utilized that public comment to formulate a proposal creating an initial multi-jurisdictional disclosure system between the United States and the Canadian provinces of Ontario and Quebec. See Securities Act Release No. 6841. 44 SEC Docket (CCH), at 56-57 (July 24, 1989); Quinn, Internationalization, supra. Thus the United States in essence adopted the issuer nationality approach with respect to issuers from these two provinces. The SEC amended that system on October 10, 1990. See Securities Act Release No. 33-6879, 47 SEC Docket (CCH), at 526-27 (Oct. 22, 1990); Quinn, Internationalization, supra, at 34 . In the succeeding eight years, however, no other foreign jurisdiction has qualified for such special treatment. See Securities Act Release No. 6902, 49 SEC Docket (CCH), at 260 (June 21, 1991); Securities Act Release No. 6902A. 51 SEC Docket (CCH), at 66 (Mar. 23. 1992) [hereinafter Release No. 6902A ]; International Securities Markets, 961 Pract. L. INST. 77. $96-97$ (1996).

22. See Securities Act Release No. 4708, Fed. Sec. L. Rep. (CCH) If 1361, at 1362 (July 9 , 1964) [hereinafter Release No. 4708].

23. See Release No. 6437, supra note 21; Fanto, supra note 6: see also supra note 21.

24. The Commission's rationale is as follows:

[T]he Commission has traditionally taken the position that the registration requirements of Section 5 of the Act are primarily intended to protect American investors .... [I]t is immaterial whether the offering originates from within or outside of the United States. whether domestic or foreign broker-dealers are involved and whether the actual mechanics of the distribution are effected within the United States. 


\section{Regulation $S$}

In 1988, the SEC issued a release first proposing its subsequently adopted Regulation S rules concerning Securities Act registration exemptions for offers and sales abroad. In this release, the SEC articulated a shift in goal concerning the appropriate reach of the entire U.S. disclosure regime. The Commission states:

[T] he registration of securities is intended to protect the U.S. capital markets and all investors purchasing in the U.S. market, whether U.S. or foreign nationals. Principles of comity and reasonable expectations of participants in the global markets justify reliance on laws applicable in jurisdictions outside the United States to define disclosure requirements for transactions effected offshore. As investors choose their markets, they would choose the disclosure requirements applicable to such markets. ${ }^{25}$

Thus concern with where the transaction is effected, which in the past had been simply a proxy for the likely residency of the person buying the security, becomes an end in itself.

How far the SEC will go in carrying out this articulated change in goal, however, is not clear. So far, there has not been a major change in practice. The SEC's immediate impetus for proposing Regulation $\mathrm{S}$ - its desire to lay out clearer, more coherent standards for exempting both U.S. and foreign issuers when they make public offerings arguably only to the public abroad - was much narrower than the fundamental shift in rationale suggested by the release. Reflecting this, the rules actually adopted do not provide a wholesale exemption for every transaction effected abroad. Rather, the focus is on two concerns. The first is preventing directed selling efforts in the United States of unregistered shares nominally only offered abroad. The second is preventing the "flowback" into the United States of unregistered shares initially sold abroad, particularly where the issuer is also not providing periodic disclosure under the U.S. regime. ${ }^{26}$

Release No. 4708, supra note 22, at 1362 (emphasis added). The SEC mentions offerings directed toward United States servicemen abroad and, because of their close connection with United States exchanges, offerings through the facilities of Canadian stock exchanges as ones not free from the registration requirements. See John H. Ehrlich, Comment, Internationalization of Stock Markets: Potential Problems for United States Shareholders, 7 Nw. J. INTL. L. \& Bus. 532, 540 (1986).

25. Initial Proposing Release, supra note 8 , at 89,128 .

26. Regulation $S$ was proposed by the SEC in June 1988. See InITIAL Proposing RE. LEASE, supra note 8. It was reproposed in 1989. See Securities Act Release No. 6838, [1989 Transfer Binder] Fed. Sec. L. Rep. (CCH) II 84, at 426 (July 11, 1989), 43 SEC Docket (CCH), at 2008 (1989) [hereinafter Reg S Reproposing Release]. The Commission adopted Regulation S on April 24, 1990. See Securities Act Release No. 6863, [1989-90 Transfer Binder] Fed. Sec. L. Rep. $(\mathrm{CCH}) \$ 84$, at 524, 46 SEC Docket $(\mathrm{CCH})$, at 52 (Apr. 
The Regulation S rules cover both U.S. issuers and foreign issuers. Rule 901 provides for an exemption from the Section 5 registration process for "offers and sales that occur outside the United States." 27 Rule 903, a safe harbor, deems offers and sales by issuers, underwriters, and dealers meeting certain stated requirements to be ones occurring "outside the United States." 28 To qualify for this safe harbor exemption, the offer must be made only to persons outside the United States, ${ }^{29}$ it must be reasonably believed that the purchasers are outside the United States when they place their orders, ${ }^{30}$ and there must be no directed selling efforts in the United States. ${ }^{31}$ Qualification may also require meeting additional conditions designed to discourage flowback to the United States. The need to meet these additional conditions and their severity depends on factors suggesting the likelihood of such flowback and the extent of its damage if it does occur. Such factors include the nationality of the issuer, the nature of the security, whether the issuer's currently outstanding securities trade in the United States, and whether the issuer currently provides periodic disclosure under the Exchange Act. ${ }^{32}$

a. U.S. issuers. Under Regulation S, a U.S. issuer that scrupulously offers its shares only to persons residing abroad and lists the shares only on a foreign stock exchange will ultimately still have difficulty avoiding compliance with U.S. disclosure requirements. This is true even though purchasers of its shares, both primary and secondary, would have chosen to acquire their shares in a market

24, 1990) (codified at 17 C.F.R. $\$ \$ 230.901-.904$ (1998)) (hereinafter REG S Adopting ReLEASE].

For an overall description and analysis of Regulation S, see RICHARD W. JENNINGS ET al., Securities Regulation: Cases and Materials 519-21, 1594-612 (7th ed. 1992); Louis Loss \& Joel Seligman, Securities Regulation 792 (3d ed. 1989 \& Supp. 1996): Don Berger, Offshore Distribution of Securities: The Impact of Regulation S, 3 TRANSNaTL. Law. 575 (1990); John Regis Coogan \& Thomas C. Kimbrough, Regulation S Safe Harbors for Offshore Offers, Sales and Resales, 4 Insights (P-H) 3 (No. 8, Aug. 1990); Samuel Wolff. Offshore Distributions Under the Securities Act of 1993: An Analysis of Regulation S, 23 L. \& POLY. INTL. Bus. 101 (1991-92).

27. 17 C.F.R. $\$ 230.901$.

28. See 17 C.F.R. $\S 230.903$.

29. See SEC Regulation S, 17 C.F.R. \& 230.903(a); 17 C.F.R. $\$ 230.902(i)(1)(i)$.

30. See 17 C.F.R. $\$ 230.903($ a); 17 C.F.R. \& 902(i)(1)(ii).

31. See 17 C.F.R. $\$ 230.903(b)$.

32. See 17 C.F.R. $\$ 230.903(\mathrm{c})$. Where factors suggest that the likelihood of flowback is significant, an issuer that currently provides periodic disclosure under the Exchange Act does not need to impose as severe measures to prevent flowback as one that does not provide such disclosure. Compare Rule 903(c)(2) and Rule 903(c)(3). The theory is that in the case of the issuer currently providing Exchange Act periodic disclosure, any flowback that does occur causes less damage. 
outside the United States and hence, according to the newly articulated goal of market protection, have chosen foreign disclosure requirements as well. For such an issuer, the conditions imposed to prevent flowback to the United States would make it difficult or impossible to construct a practical scheme to market its shares abroad. And even if the issuer succeeded at that, its victory would likely be Pyrrhic: soon after, it would probably have to provide the same information under the 1934 Act periodic disclosure requirements. ${ }^{33}$

\section{b. Foreign issuers. A foreign issuer that offers its securities} only to persons residing abroad is likely to avoid the need to comply with U.S. disclosure requirements. To start, the foreign issuer will find it easier to qualify for an exemption under Regulation $\mathrm{S}$ from disclosure at the time of offering. The only tricky question here is whether it will be considered to have engaged in a directed selling effort in the United States if it creates publicity abroad that ends up reaching not only investors abroad, but investors in the

33. Consider first a privately held issuer whose operations and management are predominantly in the United States and whose initial shareholders are primarily U.S. residents. It decides to go public only abroad. Even if the issuer is incorporated (or reincorporated) abroad, such an issuer would not qualify as a "foreign issuer" under Regulation S Rule $902(\mathrm{f})$ because, at the time of the offering, more than $50 \%$ of its shares would be U.S. held and it would have a U.S. economic center of gravity. Thus the only safe harbor from new issue registration for which the issuer could qualify would be Rule 903 (c)(3). which imposes the most severe conditions to prevent flowback to the United States. See supra note 32. Under Rule $903(\mathrm{c})(3)$, the offering must be constructed in such a way that the purchasers are nonU.S. residents who for a year agree to resell only to other non-U.S. residents who themselves agree to similar restrictions. This prevents the shares for a year from being listed to trade in an ordinary fashion even on a foreign stock exchange. Because of the consequent reduction in liquidity, these conditions greatly reduce the marketability of the shares. Moreover, even if this previously privately held issuer were able and willing to market its securities to the non-U.S. public under these difficult circumstances, it would still not escape for long the U.S. regime's periodic disclosure requirements under the Exchange Act, unless the offering resulted in a majority of its shares being held by non-U.S. residents. See infra notes 36-39 and accompanying text (discussing periodic disclosure).

Now consider an issuer with the same U.S. connections that is already publicly traded in the United States. It would already be providing Exchange Act periodic disclosure. Because of this, it could qualify for the Rule $903($ c)(2) safe harbor. The conditions designed to discourage flowback under Rule 903 (c)(2) would not create the same roadblocks to the shares being traded on a foreign exchange immediately after the offering. But ultimately the already publicly traded U.S. issuer would find it even harder than the previously privately held one to avoid continued imposition of the Exchange Act periodic disclosure requirements. This would be so even if the offering were so large that it led to a majority of the issuers' shares being held by non-U.S. residents. There are only two exemptions from 1934 Act periodic disclosure based on an issuer's foreign aspects: Rule 12g3-2(a) and Rule 12g3-2(b). See infra notes 36-39 and accompanying text. Neither is likely to be available to the issuer considered here. A Rule 12g3-2(a) exemption would be unavailable since the issuer would still presumably have more than 300 U.S. resident shareholders. A Rule 12g3-2(b) exemption would be unavailable because of Rule $12 \mathrm{~g} 3-2(\mathrm{~d})(1)$, which denies the exemption to issuers whose shares are already Exchange Act registered. 
United States - something happening with ever greater frequency as the financial media become increasingly international. ${ }^{34}$ As long as it avoids this problem, a foreign issuer that does not have any securities currently publicly traded in the United States can engage in a public offering abroad and qualify for an exemption under Regulation $\mathrm{S}$ from Securities Act disclosure without having to meet any additional conditions designed to prevent flowback. ${ }^{35}$ And, as discussed below, the issuer will also not likely be subsequently required to provide Exchange Act periodic disclosure as long as it does not subsequently list its shares on a U.S. stock exchange or NASDAQ.

Thus, the U.S. practice with respect to foreign issuers conforms much more closely to the SEC's market protection goal. When purchasers, including U.S. purchasers, decide to acquire the shares of a foreign issuer offered or traded only abroad, the purchasers, in their

34. For offers and sales to be within the "safe harbor" provisions of Rule 903 that deem them as "occur[ring] outside the United States," there must be inter alia, "no directed selling efforts ... made in the United States." Rule 903(b). "Directed selling efforts" are in turn defined in Rule 902(b)(1) as "any activity undertaken for the purpose of, or that could reasonably be expected to have the effect of, conditioning the market in the United States for any of the securities being offered" (emphasis added). "Conditioning" is a term of art with regard to Section 5. The SEC has stated that

$[\mathrm{T}]$ he publication of information and statements, and publicity efforts, generally, made in advance of a proposed financing, although not couched in terms of an express offer, may in fact contribute to conditioning the public mind or arousing public interest in the issuer ... in a manner which raises a serious question whether the publicity is not in fact part of the selling effort.

Securities Act Release No. 3844, 17 Fed. Reg., at 835 (Oct. 4, 1957). The SEC gave as an example of such conditioning a speech by an executive of a prospective issuer before a securities analysts meeting in which projections of sales and profits were provided. See id. In a subsequent enforcement decision, the SEC found a press release provided to the New York press by an underwriter concerning the future operations of a prospective issuer to be an "offer" in violation of Section 5(a) by both the underwriter and the issuer, stating that it "is equally applicable whether or not the issuer or the surrounding circumstances have ... news value." Carl M. Loeb, Rhoades \& Co., 38 S.E.C. 843 (1959).

The SEC, in its statements concerning the impact of news conferences on the availability of a Regulation $S$ exemption, has indicated, however, that it may not be as strict in its interpretation of the term "conditioning" here as it has been in the purely domestic context. In Preliminary Note 7, it states that nothing in the Regulation "precludes access by journalists for publications with a general circulation in the United States to offshore press conferences, press releases and meetings with company press spokespersons ... provided that the information ... is not intended to induce purchases of securities by persons in the United States" (emphasis added). The text of the initial release proposing Regulation used similar language, but makes clear that, at least at that earlier point, the SEC remarks concerned only corporate news of foreign issuers. See InItial Proposing Release, supra note 8, at 91 89.132.

The SEC recently adopted a safe harbor relating to this question under a new Securities Act Rule 135e. See Securities Act Release No. 33-7470, 65 SEC Docket (CCH), at 1543 (Oct. 10, 1997). The Rule provides that for foreign issuers, the invitation to a U.S. journalist to participate in an off-shore press activity in connection with an offering does not generally constitute a "directed selling effort" under Regulation S.

35. See 17 C.F.R. \& $230.903(\mathrm{c})(1)$. 
decision to acquire shares in a market outside the United States, are in fact choosing foreign disclosure requirements as well.

\section{B. Issuer Disclosure Triggered by Secondary Market Transactions}

Issuers, both U.S. and foreign, can also become subject to the U.S. disclosure regime pursuant to the Exchange Act's periodic disclosure requirements. This is true whether or not they have ever engaged in a public offering registered under Section 5 of the Securities Act. ${ }^{36}$ The United States, in determining the transnational reach of these requirements, again puts some weight on each of the three national dimensions of trades in an issuer's shares: investor residency, issuer nationality, and the place of the transaction. Consistent with the traditional investor protection approach, however, issuer nationality and the place of the transaction appear to be taken into account largely because they serve as proxies of the likelihood that a significant number of U.S. investors are trading in the issuer's stock. While the articulated goal of market protection set forth in the SEC Release originally proposing Regulation S appears at least as applicable to periodic disclosure as to new issue disclosure, the SEC has not attempted any major reworking, akin to Regulation $S$, of the rules governing the reach of the periodic disclosure requirements.

\section{Foreign Issuers}

Foreign and U.S. issuers alike that wish their securities to be listed on a U.S. stock exchange, need, pursuant to Exchange Act Section 12(a), to register these securities with the SEC and thereby

36. Sections $12(\mathrm{~b})$ and $12(\mathrm{~g})$ of the Exchange Act set forth requirements for the registration of the securities of certain issuers. Exchange Act Section 13(a) requires issuers registered under Section 12 to file, in accordance with the rules and regulations prescribed by the SEC, annual reports and current information that follow up on the original Section 12 registration application or statement. An issuer that has engaged in an offering registered under Section 5 of the Securities Act must. pursuant to Exchange Act Section 15(d), provide on a continuing basis the same annual reports and current information.

Since the SEC's adoption of its integrated disclosure reforms in the early 1980s, the information concerning the issuer's management, operations, prospects, and financial status sought under the Exchange Act's periodic disclosure requirements (Form 10-K for domestic issuers and Form 20-F for foreign issuers) and under the Securities Act's new issue disclosure requirements (Form S-1 for domestic issuers and Form $\mathrm{F}-1$ for foreign issuers) is largely the same. The Exchange Act forms and the Securities Act forms each incorporate by reference the same items in Regulations $S-K$ and $S$. X. The threat of private actions for damages is less of a deterrent for violations of the Exchange Act's requirements, however. Because the Exchange Act has no equivalent to the Securities Act Sections 11 and 12, such a violation is much less likely to lead to substantial private damages awards heing imposed against the jssuer or persons such as underwriters or directors contractually related to the issuer. For a more extensive review of this subject. see Merrit1 B. Fox, Shelf Registration, Integrated Dis closure, and Underwriler Due Diligence: An Economic Analysis, 70 VA. L. REv. 1005 (1984) 
automatically become subject to the Exchange Act's periodic disclosure regime. ${ }^{37}$

The rules for publicly traded foreign issuers not wishing their shares to be listed on a U.S. exchange are more complicated. Exchange Act Section 12(g)(1) requires any issuer having assets of more than $\$ 10$ million and a class of equity securities held of record by 500 or more persons to register such securities under the Act. ${ }^{38}$ The statute makes no distinction between domestic and foreign in terms of the issuer's jurisdiction of incorporation, the residency of its shareholders, the location of its assets, or the place where its shares are primarily traded. ${ }^{39}$ The SEC has, however, pursuant to its rule-making power, exempted from these requirements any issuer that has certain specified foreign characteristics ${ }^{40}$ and that (i) has no class of equity with more than 300 holders resident in the United States, ${ }^{41}$ or (ii) furnishes the SEC with the disclosure information required by its home country's regime (this second basis not being available for issuers first listed on NASDAQ after October 1983). ${ }^{42}$ Thus, the SEC imposes the U.S. disclosure regime on for-

37. Section 12(a) prohibits any member, broker, or dealer from effecting on a national securities exchange any transaction in "any security" not registered on such an exchange in accordance with the provisions of the Exchange Act.

38. More specifically, Section $12(\mathrm{~g})(1)$ requires every issuer that is engaged in interstate commerce or whose securities are traded by use of any means of interstate commerce, and that has total assets exceeding $\$ 1$ million and a class of equity security held of record by 750 or more shareholders, to register such securities with the SEC, whereby the issuer provides information comparable to that required by a Section 12 (b) registration. Rule $12 \mathrm{~g}-3$, however, exempts from these requirements issuers with less than $\$ 10$ million in total assets.

39. The text of subsection $12(\mathrm{~g})$ as a whole, which was added by amendment to Section 12 in 1964 , clearly suggests that $12(\mathrm{~g})(1)$ is to apply to foreign issuers as well as domestic ones because there is an explicit provision in $12(\mathrm{~g})(3)$ for the SEC by rule or regulation to exempt any security of a foreign issuer. This interpretation is confirmed by the legislative history of the amendment. See H.R. REP. No. 88-1418, at 11 (1964).

40. To qualify, the issuer must be a "foreign private issuer," as that is defined under Exchange Act Rule 3(b)-4. This requires the issuer to be organized under the laws of a foreign country and, if its operations are sufficiently connected with the United States, to have no more than $50 \%$ of its voting securities held by U.S. residents.

41. See Rule 12g3-2(a).

42. See Rule 12g3-2(b). The SEC in 1983 amended the Rule to eliminate the availability of the $12 \mathrm{~g} 3-2$ (b) exemption for all foreign issuers quoted on the automated quotation system of the National Association of Securities Dealers ("NASDAQ") unless the issuer was already quoted on NASDAQ prior to the date of the amendment and was and continues to be in compliance with the requirements of the exemption. The reasoning behind eliminating the exemption was that "trading on NASDAQ is substantially the same as trading on an exchange and therefore the information available ... should be essentially the same. ..." Exchange Act Release No. 20264, 48 Fed. Reg. 46,736 (Oct. 6, 1983) [hereinafter Release No. 20264]. The "grandfathering" of what for the foreseeable future was the vast bulk of NASDAQ-quoted foreign issuers is inconsistent with that reasoning. The stated fear of the SEC, however, was the possibility that without grandfathering, a large number of NASDAQquoted foreign issuers, in order to avoid registration, would withdraw from NASDAQ, which would injure United States investors who purchased their securities when they were still quoted. See Release No. 20264, supra, at 46,737 . 
eign issuers wishing to commence listing of their securities on a national securities exchange or NASDAQ. For all others, it in essence accepts as adequate the disclosure regime of their home countries. ${ }^{4.3}$

Foreign issuers that do end up subject to the Exchange Act's disclosure regime are permitted under the applicable Form 20-F to provide somewhat less information than are U.S. issuers on matters such as the results of their separate lines of business, management compensation, and material transactions. They are also allowed to prepare their accounting statements based on home country generally accepted accounting practices (GAAP) with less reconciliation to U.S. GAAP than is required of foreign issuers registering under the Securities Act to issue new equity. ${ }^{44}$

\section{U.S. Issuers}

For the typical U.S. issuer with shares that are traded or held abroad, domestic trading or holdings in the United States are by themselves sufficient to trigger imposition of the Exchange Act periodic disclosure regime. Thus, the question of whether the foreign trading and holdings would by themselves be sufficient to trigger the regime need not be faced. The question cannot be avoided, however, where, perhaps in an attempt to avoid United States dis-

The same amendment also eliminated, with a two-year phase in, the availability of the exemption for all Canadian issuers regardless of previous status. The fact that the SEC decided not to grandfather Canadian issuers undermines its rationale for grandfathering issuers of all other foreign countries. The two-year grace period that the SEC granted Canadian issuers appears to have been a reasonably effective alternative method of protecting U.S. investors from being hurt by issuer withdrawal from NASDAQ since it provided a period of continued liquidity in U.S. markets during which those investors who needed such liquidity could sell to investors who did not - those better positioned to trade in foreign markets. Thus the fact that the SEC chose the grandfathering rather than the grace period approach for non-Canadian foreign issuers suggests that it did not want to face the larger implications of trying to impose its regime on the bulk of NASDAQ foreign issuers: the reduced opportunity for Americans to buy as well as sell these shares, the corresponding reduction in business for U.S. brokers and dealers, and the diplomatic pressures from foreign governments.

43. This acceptance of the disclosure system of the issuer's domicile has been strongly criticized by Professor Buxbaum. See Richard M. Buxbaum, Securities Regulation and the Foreign Issuer Exemption: A Study in the Process of Accommodating Foreign Interests, 54 CORNELL L. REV. 358 (1969). Some commentators have pointed out more recently that the securities of many issues that qualify for the Rule 12g3-2(b) exemptions are traded within the United States via "pink sheets." See Hal S. Scott \& Philip A. Wellons, International Finance: Transactions, Policy and Regulation 50 (3d ed. 1996) (discussing J. Cochrane et al., Foreign Equities and U.S. Investors: Breaking Down the BarriERS AND SeParating SuPPly AND DEMAND, 11-13 (NYSE Working Paper No. 95-04, 1995)). Pink sheets are stock quotations published twice daily by the National Quotation Bureau that include the names and telephone numbers of market makers. See id. In 1994, over 7,600 foreign securities, and 440 ADRs, traded through pink sheets. See id. These trades averaged $\$ 136.2$ million in daily dollar value. See id.

44. See Securities Act Release No. 6360, 46 Fed. Reg. 58,511 (Dec. 2, 1981) [hereinafter Release No. 6360]. See generally Fanto \& Karmel, supra note 21, at 9, 13-14. 
closure rules, a United States issuer with a majority of its assets and management in this country chooses to become a public company but to do so abroad, i.e., by engaging in no domestic public offerings and by facilitating the trading of its securities only abroad. ${ }^{45}$

Section 12(a) is not a problem for such an issuer since its registration requirements would only be triggered by a listing of the issuer's shares on a U.S. stock exchange. ${ }^{46}$ Section $12(\mathrm{~g})$ would be a problem, however. Wherever most of the issuer's shareholders reside the simple fact that it has gone public is enough to trigger imposition of the regime, at least as long as it remains incorporated in the United States. ${ }^{47}$ If the issuer reincorporates abroad, it might

45. Research reveals at least one previously nonpublic United States company, International Signal and Control Group, that listed and offered its shares on the London Stock Exchange in order to avoid United States disclosure. See Ehrlich, supra note 24, at 550.

46. A listing on a foreign stock exchange would not under Section 12(a) trigger a need for such an issuer to register its securities, because Section 12(a) applies only to transactions on a "national securities exchange." No foreign exchange is currently registered as a "national securities exchange." See 2 Fed. Sec. L. Rep. (CCH) If 21,310.10, at 15.705 (1989).

No foreign exchange would appear to be required to so register. Given the purposes of the sections of the Exchange Act relating to the regulation of "national securities exchanges" and their legislative history, registration of a forcign exchange would appear to be outside the contemplation of the regulatory scheme. Exchange Act Section 5 deals specifically with the legality of trading on unregistered exchanges "within or subject to the jurisdiction of the United States" if that exchange is not otherwise exempted. See 15 U.S.C. $\$ 78(\mathrm{e})$ (1994). And while the legislative history dealing specifically with that phrase is sparse and uninformative, $\S 30$ (b) of the Exchange Act sheds some light on Congress's desire to keep the extraterritorial reach of the Exchange Act's regulation of the securities business to a minimum. Section 30(b) provides that the Act "shall not apply to any person insofar as he transacts a business in securities without the jurisdiction of the United States . . ." 15 U.S.C. \& $78 \mathrm{dd}$ This clause suggests that Congress intended to distinguish between those exchanges located within the United States and those exchanges located without. See Douglas B. Spoors. Com. ment, Extraterritorial Application of the Securities Regulations: Territorialism in the Wake of the October 1987 Market Crash, 1 Transnatl. Law. 307. 317 (1988).

The SEC's Division of Market Regulation, however, in response to a letter of inquiry concerning proposed activities of a client, has suggested the possibility that a representative in the United States of a foreign exchange that distributes quotes to subscribers in the United States and receives and transmits orders for the purchase and sale of securities might have to register as a national exchange under Section 6 of the Exchange Act. See Irving Marmer. Securities and Exchange Commission, Division of Market Regulation. ['72-73 Transfer Binder] Fed. Sec. L. Rep. If 79,283, at 82,810 (1973). Even if that is the case however, it would be difficult to argue that an issuer listed on the foreign exchange is, by the act of that representative, listed on the registered exchange as well, especially if the arrangement by the representative were set up after the issuer listed on the foreign exchange. Such an argument would be equally applicable to all the foreign issuers listed on that exchange and would sug. gest that all would need to register under the Exchange Act.

47. This assumes that the issuer is not so insignificant that it has less than $\$ 10$ million in assets and that after going public it has a class of equity securities with more than 500 holders located somewhere in the world. In that case, Section $12(\mathrm{~g})(1)$ would appear to require the issuer to register its securities. Section $12(\mathrm{~g})(1)$, as we have seen, makes no distinction between foreign and domestic security holders. Because foreign issuers are covered unless exempted pursuant to a rule or regulation, see supra note 39 an issuer, being from the Lnited States, surely would, absent such an exemption, be covered as well, even if most of its shareholders are abroad. No exemption is available for this issuer. Rule $12 \mathrm{~g} 3-2$ is the only exemption that concerns the foreign characteristics of securities potentially subject to Exchange Act 
escape the U.S. disclosure regime, but the requirements for doing so are strict. Any public offering of its securities must be made exclusively abroad, and, from the moment it becomes a public company - whether through a public offering or by its share ownership growing in some other fashion to 500 or more holders - a majority of its shares must be held by persons residing abroad. ${ }^{48}$ If the issuer meets these requirements, it would be entitled to an exemption on the same basis as a foreign issuer. ${ }^{49}$

registration. See supra notes $38-44$ and accompanying text. Neither branch of the rule would provide an exemption because both require the issuer to be a "foreign private issuer." See supra note 40 . A corporation, to be a "foreign private issuer," must, under Rule $3 \mathrm{~b}-4$, be incorporated under the laws of a foreign country.

At least four issuers that are incorporated in the United States but have fewer than 300 United States resident shareholders have applied, however, pursuant to Exchange Act Section 12(h), for an order of the Commission exempting them from registration under Section $12(\mathrm{~g})$. Section $12(\mathrm{~h})$ is a catch-all provision that provides for such exemptions where "the Commission finds, by reason of the number of public investors, amount of trading interest in the securities, the nature and extent of the activities of the issuer, income or assets of the issuer, or otherwise, that such action is not inconsistent with the public interest or the protection of investors." In each case, the issuer's argument for an exemption is that the policy enunciated in Release No. 4708 , supra note 22 and accompanying text, - that the primary purpose of the Securities Act registration requirements is to protect United States investors - should apply to the Exchange Act registration requirements as well. In each case, the Commission appears not to have issued the requested order, but the staff of the Division of Corporate Finance stated that it would not raise any objection if the issuers did not register their securities under Section 12(g). See Equitable American Property Company, Inc., SEC No-Action Letter, 1989 WL 246608 (Dec. 19, 1989); Paribas Properties, Inc., SEC No-Action Letter, 1988 WL 233751 (Feb. 29, 1988); States Properties, Inc., SEC No-Action Letter, 1987 WL 108725 (Nov. 30, 1987); Petrogen Petroleum, Inc. SEC No-Action Letter, 1987 WL 108480 (Oct. 12, 1987).

As of January 1987, there were 14 United States companies traded on the London Unlisted Securities Market. For most of them, however, the reported attraction of London was the lower costs of an initial public offering rather than avoidance of United States disclosure rules. See Philip Coggan. Low costs attract, Fin. Times, Jan. 20, 1987 (Survey). at vi. Since that time, the London Stock Exchange has closed the Unlisted Securities Market (USM) to make way for its new creation, the Alternative Investment Market (AIM). See Christopher Price, Opportunities for Investors, Fin. Times, Mar. 14. 1997. Most of the companies previously listed on the USM have found their way to AIM which now has 259 listed issuers. See $i d$. At least one company, however, moved to NASDAQ. See LBMS to Opt for American Listing. The Times of London, Sept. 29, 1995.

48. An issuer that is incorporated abroad and meets these requirements is, under Exchange Act Rule 3b-4(b), a "foreign issuer" despite having a majority of its assets and management in the United States. It can be exempt from registration under Rule $12 \mathrm{~g} 3-2$ if it has no more than 300 holders resident in the U.S. or if it furnishes the SEC with the disclosure information required by authorities abroad, see supra notes $40-42$ and accompanying text, but only if it qualifies under Rule 3b-4(c) as a "foreign private issuer." That requires not only foreign incorporation, but also that no more than $50 \%$ of the issuer's outstanding voting securities be held by United States residents. This might or might not be true of a corporation that was originally owned by its founders, private offering investors, and employees and that subsequently goes public abroad.

49. See Rule 36-4(c). 


\section{Conclusion}

In summary, U.S. practice currently works as follows. Issuers that I categorize as U.S. nationals - those with their economic center of gravity in the United States - are generally subject to the U.S. regime. Potential escape is available, but only to those who can pass through the "eye of a needle": (i) they must be incorporated abroad, (ii) public offerings of their securities must be made exclusively abroad, and (iii) from the moment they become a public company, a majority of their shares must be held by persons residing abroad. For those that pass through the eye, actual escape depends on the same factors as apply to foreign issuers.

Foreign issuers will be subject to the U.S. disclosure regime if they offer their shares in the United States or list them on a U.S. stock exchange or NASDAQ. Otherwise they can probably escape the U.S. regime.

Thus, where an issuer's nationality is U.S., the issuer is very likely to need to comply with the U.S. regime. Where a significant number of transactions in an issuer's shares are effected in the United States, it is fairly likely that the U.S. regime will be applied as well, even if the issuer is foreign. Where a significant number of purchasers of an issuer's shares are U.S. residents but the issuer is foreign and the shares are neither offered in the United States nor listed on a stock exchange or NASDAQ, the U.S. regime will probably not be applied.

\section{Legal Constraints on the SEC, the Courts, and Congress in Deciding Issues of Statutory Reach}

The SEC, the courts, and Congress each play a role in determining the reach of the U.S. disclosure regime. The primary focus of this Article is on what approach would maximize U.S. economic welfare. Its main function, therefore, is to guide these institutions as to what constitutes good policy. Before undertaking this analysis, however, it is helpful to take a brief look at the existing legal constraints on each of them in deciding issues of statutory reach. This look will give us a sense of the scope and practicality of the reforms necessary to implement the recommended changes.

The SEC, the courts, and Congress, it will be seen, each currently enjoys broad discretion to decide the reach of the U.S. disclosure regime. There do not appear to be serious constraints that would prevent any of them from adopting the issuer nationality approach to statutory reach recommended here, given. as the rest of 
the Article shows, its superior ability to discriminate between issuers whose disclosure behavior primarily affects U.S. welfare and issuers whose disclosure behavior primarily affects the welfare of other countries.

\section{A. The SEC}

The SEC determines in the first instance which of the world's issuers are covered by the U.S. disclosure regime and which are not. It does so through its power to make rules, issue interpretations, create exemptions, and take enforcement actions. ${ }^{50}$ Its power to act in any of these ways must, as a doctrinal matter, be exercised within the confines of what is authorized by statute. A number of factors, however, make this a very loose constraint when it comes to SEC decisions concerning statutory reach.

First, the SEC is an expert agency. Because of this status, its interpretation of what the securities laws cover is given considerable deference by the courts. ${ }^{51}$ This deference includes SEC determinations concerning the reach of the U.S. disclosure regime, ${ }^{52}$ since the courts consider the question of statutory reach to be a matter of statutory interpretation. ${ }^{53}$

Second, Congress has explicitly given the SEC broad powers of exemption relevant to the reach of the whole U.S. disclosure regime, the exercise of which should be given even greater judicial deference. ${ }^{54}$ Until 1996, the SEC had these explicit powers only with respect to Exchange Act section 12(g)(1), which imposes the Act's ongoing, periodic disclosure requirements on all publicly held issuers not traded on a national stock exchange. Under these powers, set out in section $12(\mathrm{~g})(3)$ and $12(\mathrm{~h})$, the SEC may grant such an issuer an exemption from the requirements of Section $12(\mathrm{~g})(1)$ if

50. For a review of the SEC's actions in this regard, see supra Part I.

51. See Chevron U.S.A., Inc. v. Natural Resources Defense Council, Inc., 467 U.S. 837, 844 (1984) (stating that a court should not substitute its construction of a statute for a reasonable interpretation of an administrative agency); International Bhd. of Teamsters v. Daniel, 439 U.S. 551, 566 n.20 (1978); 10 Louis Loss \& Joel Seligiman, Securities Regulation 4812-15 (3d ed. 1996).

52. See, e.g., Bersch v. Drexel Firestone, Inc., 519 F.2d 974, 986 (2d Cir. 1975), cert. denied, 423 U.S. 1018 (1975). Judge Friendly states that the anti-fraud provisions of the federal securities laws apply to many transnational transactions not within the registration requirements. He takes as his starting point for this statement the SEC's own interpretation of the reach of the registration requirements as articulated in Release No. 4708, supra note 22.

53. See infra notes 63-69 and accompanying text.

54. In Chevron, the Court held that agency regulations promulgated pursuant to explicit gaps left for the agency to fill should be "given controlling weight unless they are arbitrary, capricious, or manifestly contrary to the statute." 467 U.S. at 843-44. 
the SEC finds that doing so is not inconsistent with the public interest or the protection of investors. ${ }^{55}$

Part III of this Article establishes that compliance by an issuer with the U.S. disclosure requirements is not necessary for the prices at which U.S. investors purchase the issuer's shares to be fair. ${ }^{56}$ Exempting all such foreign issuers from these requirements is thus not inconsistent with the protection of investors. The Article as a whole shows as well that applying the U.S. regime only to U.S. issuers is the approach to statutory reach that most enhances U.S. economic welfare. Such an exemption is thus also not inconsistent with the public interest. ${ }^{57}$ Thus, under sections $12(\mathrm{~g})(3)$ and $12(\mathrm{~h})$ the SEC has had for some time a sufficient basis to exempt from its periodic disclosure requirements all foreign issuers not traded on a national stock exchange, if it wishes to do so.

In 1996, Congress explicitly gave the SEC further exemptive powers relevant, among other things, to the reach of the rest of the U.S. disclosure regime, i.e, Securities Act new issue disclosure and Exchange Act periodic disclosure imposed on issuers whose shares are traded on a national stock exchange. ${ }^{58}$ The criteria for granting

55. See supra notes 38-42 and accompanying text for a discussion of Section 12(g)(1) and the exemptions thereunder currently granted by the SEC. Under Exchange Act Section $12(\mathrm{~g})(3)$, the SEC has the power to exempt from the requirements of Section $12(\mathrm{~g})(1)$ any foreign issuer where the SEC "finds that such exemption is in the public interest and is consistent with the protection of investors." More generally, under Exchange Act Section 12(h), the SEC has the power to exempt from the requirements of Section 12(g)(1) any issuer, foreign or domestic, where the SEC finds "by reason of the number of public investors, amount of trading interest in the securities, the nature and extent of the activities of the issuer, income or assets of the issuer or otherwise, that such action is not inconsistent with the public interest or the protection of investors." The inclusion of the catch-all phrase "or otherwise" in the list of reasons suggests that, as with Section $12(\mathrm{~g})(3)$, the SEC's main focus should be on the exemption not being inconsistent with the public interest and the protection of investors.

56. See infra section III.A.1. For a more extensive discussion of this point, see Fox, Disclosure in a Globalizing Market, supra note 1 , at 2533-39.

57. The argument that an exemption for all foreign issuers would be available under Section $12(\mathrm{~h})$ is reinforced by the fact that "the nature and extent of the activities of the issuer" is listed as one of the reasons to grant the exemption. See supra note 55. As shown in Part III infra, differences between U.S. and foreign issuers in terms of "the nature and extent of [their] activities" is a primary reason why it would be welfare enhancing to treat them differently.

58. The National Securities Market Improvement Act of 1996 amended the Securities Act of 1933 to add Section 28, providing that:

The Commission by rule or regulation, may ... exempt . . . any class or classes of persons, securities, transactions, from any provision or provisions of this title . . to the extent that such exemption is necessary or appropriate in the public interest, and is consistent with protection of investors,

15 U.S.C.A. $\$ 77 \mathrm{z}-3$ (1997), and to add Section 2(b) providing that:

Whenever pursuant to this title the Commission is engaged in rulemaking and is required to consider or determine whether an action is necessary or appropriate in the public interest, the Commission shall also consider, in addition to the protection of investors, whether the action will promote efficiency, competition, and capital formation. 
such exemptions are just affirmatively stated versions of the criteria discussed above - the protection of investors and the public interest. ${ }^{59}$ Thus, now the SEC has, under explicit powers, a sufficient basis to exempt all foreign issuers from the whole regime, if it so wishes. The argument is given added force by a new statutory admonition that the SEC, in deciding whether to grant exemptions, "shall also consider, in addition to the protection of investors, whether the action will promote efficiency, competition, and capital formation." 60

The final reason the SEC has broad discretion is that, as a practical matter, it is usually the final arbiter of the reach of the statute it administers. There is only a small chance that any SEC determination concerning the reach of its disclosure requirements will be subject to a court review. Where an issuer is granted an exemption, it will not want the determination upset. Where an issuer is not granted an exemption, it will likely find a challenge not worthwhile. ${ }^{61}$ Significantly, research does not reveal a single published opinion with a holding relating to the reach of the U.S. disclosure regime. ${ }^{62}$

15 U.S.C.A. $\$ 77 \mathrm{~b}$ (b) (emphasis added). The 1996 Act made essentially identical amendments to the Securities Exchange Act of 1934 by the addition of Sections 36 and 3(f). See 15 U.S.C.A. $\$ \$ 78 \mathrm{c}(\mathrm{f}) ; 80 \mathrm{a}-2(\mathrm{c})$.

59. See supra note 58.

60. See supra note 58 .

61. With regard to new issue disclosure, where the SEC has made a determination that an issuer wishing to engage in a public offering of securities is covered by Section 5 of the Securities Act, the issuer wants its financing at the time it determines it needs the funds, not after several years of litigation. Thus, rather than contest the SEC determination, the issuer will decide either that the advantages of having a public offering are worth the costs of registration or that it will seek the funds some other way. Where the SEC has determined that an issuer is not covered by the new issue disclosure regime, there is generally no one to complain. There is, however, the possibility that if the stock price goes down significantly after the offering, the legitimacy of the SEC determination could be challenged in a private suit for recisionary damages under Securities Act Section 12(a)(1). The plaintiff's theory would be that, contrary to the SEC's determination, the issuer was not exempt and hence its failure to file a registration statement was a violation of Section 5 .

With regard to periodic disclosure, in cases where the SEC has determined that an issuer is covered, the issuer is not under the same time pressures as with a primary issue. The issuer would have to weigh, however, whether the costs of protracted litigation concerning a matter to which the court will give the SEC determination great weight, see stupra note 54 , is worth the benefit of avoiding the U.S. disclosure regime. In cases where the SEC has determined that an issuer is not covered, the issuer is not going to complain. And there is no one else available to complain because there appears to be no private right of action available to private litigants where an issuer fails to make periodic disclosure filings that it is legally required to make. See Loss \& Seligman, supra note 51, at 4301 n.262.

62. There are reported cases with holdings concerning the reach of the antifraud provisions of the securities laws, but they explicitly provide that they are not reliable guides as to the reach of the disclosure regime. See, e.g., Consolidated Gold Fields v. Minoroco. S.A.. 871 F.2d 252, 262-63 (2d Cir. 1989). 


\section{B. The Courts}

Should a court be asked to review or enforce an SEC action involving the reach of the U.S. disclosure regime, it would treat the question as a matter of statutory interpretation. ${ }^{63}$ The same would be true should the court need to make a decision concerning such a question arising in a litigation between private parties. Given that there is no explicit statutory language or clear legislative history concerning the reach of the U.S. disclosure regime, ${ }^{64}$ congressional intent is difficult to discern. ${ }^{65}$ We can get some idea of how a court would deal with the issue, however, from decisions concerning the reach of other statutes where Congress has similarly made no signs concerning their reach. The starting point is a presumption that un-

There is one reported case involving statutory reach issues in which the SEC sought a preliminary injunction and the appointment of a receiver pendente lite based on a complaint that the defendant violated Securities Act Sections $5(\mathrm{a})$ and $5(\mathrm{c})$ (the mandatory disclosure provisions), Securities Act Section 17(a) (the antifraud provisions of the Securities Act), and Exchange Act Section 10(b) and Rule 10b-5 (the antifraud provisions of the Exchange Act). See SEC v. United Fin. Group, Inc., 474 F.2d 354. 356 \& n.2 (9th Cir. 1973). The district court granted the relief and the Ninth Circuit affirmed. The allegations suggest that several related issuers incorporated abroad and controlled by the defendant engaged in public offerings that were primarily aimed at persons abroad but to which at least a few Americans responded (perhaps as a result of reading ads in overseas editions of American newsweeklies while the U.S. purchasers were temporarily abroad). While the Ninth Circuit found that the district court had subject matter jurisdiction under both the Securities Act and the Exchange Act, it based this conclusion on a finding that a prima facie case of the probable cxistence of fraud had been demonstrated due to misleading statements and omissions in the offering prospectuses. See United Fin. Group, 474 F.2d at 358 . The court of appeals does not mention any showing of a failure to file registration statements for the offerings, see United Fin. Group. 474 F.2d at 358 n.9. which would be the essence of a Section 5 violation and would be beyond factual dispute. This suggests that the court did not confront the question of whether there was subject matter jurisdiction with regard to the Section 5 part of the complaint. Given the court's finding on the fraud aspect of the case, such a determination was not necessary in order to affirm the district court's injunction and appointment of a receiver.

63. See IIT v. Vencap, Ltd., 519 F.2d 1001. 1016 (2d Cir. 1975) (quoting Steele v. Bulova Watch Co., 344 U.S. 280, 282-83 (1952))

64. A partial exception to this statement is necessary with respect to the requirement, under Exchange Act Section 12(g)(1), for ongoing, periodic disclosure imposed on publicly held issuers that are not traded on a national stock exchange. The structure of the Act and legislative history suggest that Congress intended $12(\mathrm{~g})(1)$ to be imposed on every such issuer, regardless of nationality, unless the SEC exempted it. See supra notes $38-39$ and accompanying text.

65. Judge Friendly, faced with making a determination under similar circumstances concerning the reach of the Exchange Act's antifraud provisions under Section 10(b) and Rule $10 \mathrm{~b}-5$, gave the following candid description of the process that he followed:

We freely acknowledge that if we were again asked to point to language in the statutes. or even in the legislative history, that compelled these conclusions. we would be unable to respond. The Congress that passed these extraordinary pieces of legislation in the midst of the depression could hardly have been expected to foresee the development of off-shore funds thirty years later. . . Our conclusions rest on case law and commentary concerning the application of the securities laws and other statutes to situations with foreign elements and on our best judgment as to what Congress would have wished if these problems had occurred to it.

Bersch v. Drexel Firestone, Inc., 519 F.2d 974, 993 (2d Cir. 1975). 
less the contrary intent appears, Congress intends its statutes to govern only behavior occurring within the United States. ${ }^{66}$ There are two important exceptions to this presumption. One is where regulation of behavior occurring abroad is necessary to effect the basic purposes of the statute. ${ }^{67}$ The other is where the behavior abroad is intended to, and has, significant effects in the United States. ${ }^{68}$

The presumption that statutes govern only conduct in the U.S. and its two major exceptions combine to give the courts a great deal of discretion with respect to the regulation of transnational transactions. There is often ambiguity as to whether the most significant behavior potentially subject to regulation occurred at home or abroad. And in a case in which such behavior clearly did occur abroad but that involves significant U.S. elements, a case can usually easily be made both for and against the application of each of the exceptions.

This apparent discretion might appear at least somewhat limited by a further presumption that absent explicit language to the contrary, Congress does not intend the reach of the statute to exceed what is permitted under international law. ${ }^{69}$ As discussed immediately below, however, this presumption would not pose a significant constraint on a court trying to decide issues of the reach of the U.S. disclosure regime on the basis of the criteria set out in this article what would maximize U.S. economic welfare, and whether the issuer's disclosure behavior affects primarily the welfare of U.S. residents or the welfare of residents of some other country. In particular, it certainly would not constrain a court from interpreting the statute as incorporating the issuer nationality approach recommended here.

\section{Congress and Its Constraints Under International Law}

Congress, through statutory language, can explicitly specify the reach of its statutes. It should not, however, extend a statute to reach conduct beyond what international law permits, i.e., conduct outside of United States "jurisdiction to prescribe." The brief review below suggests that the issuer nationality approach recommended here produces results that are clearly fully within U.S.

66. See Blackmer v. United States, 284 U.S. 421, 437 (1932).

67. See United States v. Bowman, 260 U.S. 94 (1922).

68. See United States v. Aluminum Co. of America, 148 F.2d 416, 443 (2d Cir. 1945).

69. See Aluminum Co., 148 F.2d at 443. Cf. Leasco Data Processing Equip. Corp. v. Maxwell, 468 F.2d 1326, 1334 (2d Cir. 1972). 
jurisdiction to prescribe. ${ }^{70}$ The investor residence and location of transaction approaches, however, call for regulation in some cases where the presence of jurisdiction to prescribe is only arguable.

The conduct that is the subject of this Article generally involves some person's affirmative action relating to an issuer's shares combined with the issuer's disclosure or non-disclosure of certain information. The United States regulates the conduct by forbidding the person from undertaking the affirmative action unless the issuer discloses the information. The question of the transnational reach of U.S. disclosure regulation arises because at least one dimension of the situation - the residency of a share buyer, the location of a share transaction, or the nationality of the issuer - involves the United States and at least one other dimension involves another country.

The process of determining whether the United States has jurisdiction to prescribe regulation of any given kind of conduct involves two steps. The first step is to assess whether the United States has prima facie jurisdiction to prescribe. The United States has prima facie jurisdiction to prescribe several categories of conduct that are defined in terms of the conduct's various national dimensions. If the conduct in question does not fall into any of these categories, the United States has no jurisdiction to prescribe. If it does fall into one or more of the categories, we go on to the second step: assessing how great an interest the United States has in the conduct and how that compares with any other state's interest in the United States not regulating the conduct. The first step is relatively mechanical and the second step more nuanced. The nature of the inquiry called for by the second step is briefly described in this Part,

70. This review is based primarily on the RESTATEMENI (THIRD) OF FORFign ReLA TIONS LaW of the UNited States (1987) [hereinafter Restatement]. A full examination of the constraints imposed by international law on the reach of the U.S. disclosure regime is outside the scope of this Article and would need to go well beyond the Restatement. The RESTATEMENT, however, is considered an authoritative statement of the general U.S. view of international law. Its provisions concerning jurisdiction to prescribe provide a useful way of structuring a discussion of the underlying issues involved in this limit on the reach of the U.S. disclosure regime.

The Restatement contains three sections of particular relevance. Section 402 sets out several kinds of conduct with respect to which a state has prima facie jurisdiction to prescribe regulations. Section 403 prohibits exercise of jurisdiction to prescribe on any of these prima facie bases if (1) such exercise is unreasonable (an evaluation of which can, in part, be made by consideration of a stated list of factors) or (2) such exercise is reasonable, but another state has a conflicting prescription and the other state's interest in exercising jurisdiction is clearly greater. Section 416 applies the general principles set out in 402 and 403 to the reach of the U.S. securities laws. It lists situations in which exercise of jurisdiction is, in essence. per se reasonable and lists a set of factors to determine reasonableness for situations outside that list. 
but much of the rest of this Article helps provide answers to the questions that such an inquiry poses.

\section{Bases for Prima Facie Jurisdiction to Prescribe}

a. Conduct occurring within the territory of the regulating state. One basis for jurisdiction to prescribe is conduct occurring within the territory of the state seeking to regulate it. ${ }^{71}$ This basis would cover the disclosure behavior of many, but not all, of the issuers that the transaction location approach calls for reaching. The United States would, for example, have prima facie jurisdiction on this basis to prohibit a foreign issuer from offering or selling its shares in the United States, or promoting their secondary trading here, unless the issuer provided the required disclosure. This is because such activities - offers and sales of the issuer's shares and promotion of their trading - each inevitably would require the issuer (or someone contractually related to the issuer) to undertake conduct within the United States. Presumably permission to undertake these activities could be conditioned not only on providing disclosure at the time of the offer, sale, or promotion of trading, but also on the provision of ongoing, periodic disclosure thereafter.

This first basis would not cover one situation that the location of transaction approach calls for reaching: where neither the issuer nor anyone contractually related to it offered, sold, or promoted the trading of its shares in the United States, but organized trading in its shares nevertheless developed in the United States. In that situation, the issuer has undertaken no conduct occurring within the United States.

b. Conduct occurring outside the regulating state that has a substantial effect within its territory. A second basis for prima facie jurisdiction to prescribe is conduct that occurs outside of the state seeking to regulate it, but that has a substantial effect within such state. ${ }^{72}$ This category would cover many of the issuers that the in-

71. See RESTATEMENT, supra note 70 , at $\$ \S 402(1)(a), 416(1)(b)$. This basis is sometimes referred to as the "territorial principle" and involves "determining jurisdiction by reference to the place where the offen[s]e is committed." Research in International Law: Drafts of Conventions Prepared for the Codification of International Law, 29 AM. J. INTL. L. 1. 445 (Supp. 1935) [hereinafter Research in International Law]. The territorial principle "is everywhere regarded as of primary importance and of fundamental character." Id.

72. See Restatement, supra note 70 , at $\$ \$ 402(1)(\mathrm{c}), 416(1)(\mathrm{c})$. As briefly reviewed in Comment d and Reporter's Note 2 to Restatement $\$ 402$, the "effects principle" has given rise to some controversy in large part because of European reaction to the extraterritorial application of the U.S. antitrust laws. Ultimately, though, the "effects principle," just like the "conduct within territory" principle, is simply a way of identifying categories of conduct that 
vestor residency approach calls for reaching. The United States would, for example, have prima facie jurisdiction on this basis to prohibit a foreign issuer from offering or selling its shares or promoting their secondary trading, even though its actions are undertaken outside the United States, if, as a result, a significant number of investors in the United States are reasonably expected to be buyers. The United States could condition such an offer, sale, or promotion of trading sales upon the issuer providing the required disclosure. The rationale would be that if the issuer undertakes such a sale, offer, or promotion of trading, the conduct will have a substantial effect in the United States. Again, presumably the condition for allowing such activities could include not only providing disclosure at the time of the offering, sale, or promotion, but also providing ongoing, periodic disclosure thereafter.

This second basis would also provide a prima facie jurisdiction for regulating an issuer that offered, sold, or promoted organized trading of its shares only outside the United States, but where, as a predictable result of one or more of these actions, organized trading developed in the United States. Thus, the second basis covers a situation that the transaction location approach calls for reaching but for which the first basis does not provide U.S. prima facie jurisdiction to prescribe.

The more difficult cases even under this second basis are where an issuer sold, offered, or promoted the organized trading of its shares only outside the United States at some time in the past when the issuer could not have reasonably expected that a significant number of U.S. investors would later be buyers of its shares in the secondary market or that organized trading in its shares might later develop in the United States. Now, one or both of these things has happened. The investor residency approach, where U.S. investors later become buyers, and the transaction location approach, where organized trading in the United States later develops, would each

\footnotetext{
may sufficiently involve the political, social, or economic processes of a particular state as to justify that state imposing its general regulatory scheme on the conduct. The real issue at stake with the effects principle is the reasonableness of its application.

More recently, both Germany and the EC seem to have also adopted some form of the "effects principle" with regard to their own antitrust laws. as evidenced by the "wood pulp" decision. See Case 89/85, Osakeyhtiö v. EC Commission, 1988 E.C.R. 5233. Comm. Mkt. Rep. (CCH) I1 14,491. This, at least, is the U.S. view of the case. See, e.g., Charles F. Rule, U.S. Justice Department Antitrust Enforcement Guidelines for International Operations, in European/American Antitrust and Trade Law 1-1, 1-14 (Barry E. Hawk ed., 1989) (stating, "Nevertheless ... the [wood pulp] decision is very close to. if not indistinguishable from, the so called 'effects' test as applied by U.S. courts").
} 
call for the issuer to start providing ongoing disclosure. ${ }^{73}$ Here all the issuer is doing (absent regulation) is not providing the U.S. level of disclosure once U.S. investors start to become buyers or organized trading starts to develop in the United States. The earlier offer, sale, or promotion of trading could not realistically be called part of the conduct being regulated.

For the United States to have prima facie jurisdiction to impose its disclosure regime on such an issuer, inaction standing by itself not providing the U.S. level of disclosure - would have to be considered the "conduct" subject to regulation. The rationale for granting the U.S. jurisdiction would be that if the issuer instead provided the disclosure, it would have a substantial effect in the United States. ${ }^{74}$ Broadly applied, such an approach to the substantial effects basis for jurisdiction to prescribe would permit the United States to command a foreign national anywhere in the world to undertake an action he would not otherwise undertake simply because the action would have a significant beneficial effect in the United States. The United States could tell every wealthy foreign national around the world, for example, to send the U.S. Treasury one million dollars. While I believe it is possible to develop a more refined theory that could justify imposing the U.S. disclosure regime on some such issuers without also justifying the other obviously unacceptable results, the case for jurisdiction to prescribe is much less clear cut here than in other situations. ${ }^{75}$ Yet supporters of the in-

73. While these approaches would call for imposing the U.S. regime on such an issuer, the SEC does not in fact currently require it to disclose the information ordinarily required under the U.S. regime. It is, however, required to file with the SEC under Rule 12(g)(3)-2(b) the information that it must provide its own authorities. See supra note 42 and accompanying text.

74. Doing so would go beyond the examples of effects based justifications for jurisdiction to prescribe given by authorities on the subject. The examples typically involve some act of commission in one state which, performed the way it was, had a more negative effect on another state than if the act had not been performed at all: the intentional or negligent shooting of a gun in one state where the bullet crosses a state line and injures someone in another state, see Restatement, supra note $70, \$ 402$, cmt. d, or delivery of money in one state solely because of misrepresentations made in another state, see Leasco Data Processing Equip. Corp. v. Maxwell, 468 F.2d 1326, 1334 n.3 (2d Cir. 1972).

75. I argue elsewhere that among such issuers, one can probably justify imposing the U.S. regime on those that the investor residency approach calls for reaching, but that doing so requires breaking new ground and going beyond the conventional understanding of what is covered by the substantial effects basis for jurisdiction to prescribe. See Merritt B. Fox, Regulating Securities Disclosure in a Globalizing Market 82-100 (Apr. 1992) (unpublished paper presented at the Lniversity of Michigan Law and Economics Workshop. on file with author). The argument involves a recognition that purely domestic laws often usefully impose requirements on persons simply because their status suggests that they are in a good position to do something that is beneficial to someone else. In a world with increasing transnational economic interactions, such a regulation should be able to be extended transnationally in situations where it appears that the state seeking the extension is primarily motivated by an honest and reasonable belief that the regulation's benefits outweigh its costs, not by the regu- 
vestor residency and transaction location approaches do not address these problems. ${ }^{76}$

c. Conduct undertaken by a national of the regulating state. A third basis for prima facie jurisdiction to prescribe is conduct by a U.S. national, whether undertaken outside or inside that state. ${ }^{77}$ This basis would cover all of the issuers that the issuer nationality approach calls for reaching. The United States would, for example, have prima facie jurisdiction on this basis to prohibit a U.S. issuer from offering or selling its shares, or promoting their secondary trading, anywhere in the world - inside or outside the United States - unless the issuer provided the required disclosure.

d. Indirect methods of acquiring prima facie jurisdiction. The foregoing analysis suggests that there are foreign issuers that the investor residency or transaction location approach call for reaching but for whose conduct there is no clear prima facie jurisdiction to prescribe direct regulation. Another way of shaping the disclosure behavior of such issuers is for the United States to prohibit its residents from purchasing their shares and prohibit securities professionals in the United States from taking orders for such shares or

lation's capacity to work a unilateral wealth transfer. This argument would not justify imposing the U.S. regime on those among such issuers that only the transaction location protection approach calls for reaching. This is probably not a practical concern, however, since it is hard to imagine an issuer for whose shares organized trading develops in the United States, but for which there are not a significant number of U.S. buyers.

76. The Reporters' Note 4 to Restatement $\S 416$, for example, states "[f]oreign issuers of equity securities initially sold only outside the United States are also generally required to make [the disclosures called for by the U.S. regime] if the securities are held by a specified minimum number of United States residents." See RESTATEMENT, supra note 70. The inclusion of this statement implies that the Reporters believe that imposing the U.S. disclosure regime on these issuers is within the U.S. jurisdiction to prescribe, but the Note provides no explanation of why this is so.

The SEC, in its justification of the reach of the U.S. disclosure regime under the transaction location approach, makes the simple undifferentiated statement that the approach is based on a territorial approach and that "[t]erritoriality is a fundamental basis under both international law ... and the foreign relations law of the United States." See InITLAL ProPOSING Release, supra note 8, at 89, 128 n.60. It cites Section 402 of the Restatement without indicating which basis it is invoking or how inaction in one state, standing alone, justifies regulation by another state.

Admittedly, Regulation S, the proposal of which was the occasion for the SEC to articulate the transaction location approach, only imposes the U.S. regime on foreign issuers en gaging in primary offerings of securities where a significant number of U.S. investors can be expected to respond. We have just seen that this can easily be justified on the substantial effects basis. The transaction location approach's underlying goal of market protection is equally applicable to periodic disclosure, however. See supra section I.A.2 and I.B.

77. See Restatement, supra note $70, \S 402(2)$. This basis is sometimes referred to as the "nationality principle" and involves "determining jurisdiction by reference to the nationality or national character of the person committing the offense." Research in International Law, supra note 71 , at 445 . It is described by commentators as "universally accepted." See id. 
participating in their organized trading. ${ }^{78}$ The United States would have clear prima facie jurisdiction to do so under one or more of the three bases. Such prohibitions would induce at least some issuers to comply with the U.S. regime in order to have a U.S. market for their shares.

The effectiveness and enforceability of such an arrangement may be a problem, however. U.S. investors could try to evade the ban by placing their orders with brokers abroad, thereby making the orders difficult to monitor. Also, a regulation that would impose sanctions for its violation on the persons it is supposed to protect is likely to engender particularly little voluntary compliance and particularly intense political opposition.

\section{Limitations on Actual Jurisdiction to Prescribe: Considering the Intensity of U.S. Interest and That of Other Countries}

These bases provide only prima facie jurisdiction to prescribe. According to the ALI's Restatement (Third) of the Foreign Relations Law of the United States, even when one of these bases is present, a state may not exercise jurisdiction to prescribe if (1) its exercise is unreasonable, or (2) its exercise is reasonable, but another state has a conflicting prescription and the other state's interest in exercising jurisdiction is clearly greater. ${ }^{79}$ As suggested earlier, these constraints are really where the more important issues lie in jurisdiction to prescribe. ${ }^{80}$ While the constraints are articu-

78. Such an indirect method of shaping issuer disclosure behavior is in fact how the Exchange Act's periodic disclosure requirements work for issuers traded on a national stock exchange. Section 12(a) does not address issuers directly. Instead, it prohibits exchange members, brokers, and dealers from effecting transactions on such an exchange in the shares of issuers that have not registered under Section 12(b). See supra note 25. On the other hand, the new issue disclosure regulations under Section 5 of the Securities Act are effectively imposed directly on issuers and on others who might be involved in the distribution process. Under Section $12(\mathrm{~g})(1)$ of the Exchange Act, the periodic disclosure requirements for publicly held issuers not traded on a national stock exchange are also imposed directly on issuers.

79. See Restatement, supra note $70, \$ 403$.

80. The authors of a leading casebook on international transactions say of the bases for prima facie jurisdiction to prescribe just reviewed here:

To the extent that such principles permit clearer analysis and comprehension of problems of legislative reach, they serve a useful purpose. To the extent that they divert attention from underlying considerations to the mere (mechanical or conclusory) classification of particular legislation as expressing one or another principle, they do not ... [T]he fact that the transnational reach of a statute can be brought within an existing "principle" does not of itself argue for or justify that reach. . .

To resolve these questions ... [a] more particular and searching inquiry into statutory purposes, private expectations, and the policies or interests of the concerned governments may be called for ... [O]ne must identify the various national policies or interests at issue in a given case and face the problem of resolving any conflicts among them. 
lated in rather vague terms, they have their origins in identifiable prior practice. They reflect long held notions of comity in international law. ${ }^{81}$ They reflect as well recent examples of U.S. courts determining the reach of the U.S. antitrust laws based not just on the immediate interests of the United States in regulating the particular conduct involved, but also on considerations about the interests of other countries and the international system. ${ }^{82}$ Under the Restatement, determining whether one of these constraints applies when the United States seeks to apply its regulations to conduct having foreign elements depends on a variety of factors. These factors are indicators of the importance of the conduct to the United States and of the likelihood and extent of conflict with the interests of another state that U.S. regulation of the conduct would engender. 83

Henry J. Steiner et al., Transnational Legal Problems 847-48 (1994).

81. Rules of comity have been variously regarded as practices that are "followed not as a matter of obligation but of courtesy, convenience and neighborly accommodation," I.

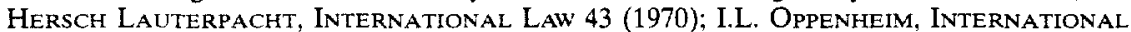
LAw: A TrEatise 33 (H. Lauterpacht ed., 8th ed. 1955), as "neither a matter of absolute obligation, on the one hand, nor of mere courtesy and good will, upon the other," Hilton $v$. Guyot, 159 U.S. 113, 163-64 (1895), and, at least in the case of rules of comity relating to concurrent jurisdiction, as part of the rules of international law that bind nations, see RESTATEMENT, supra note $70, \S 403$. Two components of Section 403 incorporate the comity concept of balancing state interests as the basis, in whole or in part, of rules requiring states to refrain from exercising jurisdiction to prescribe. First, section $403(3)$ provides that when more than one state has a reasonable basis for exercising jurisdiction over a person or activity "but the prescriptions conflict, each state has an obligation to evaluate its own as well as the other state's interest in exercising jurisdiction, in light of all the relevant factors ... [and] should defer to the other state if that state's interest is clearly greater." In addition, Section 403 (2) lists the relevant factors to be evaluated in determining whether the exercise of jurisdiction is reasonable. A number of these measure the interest of the state in regulating the activity, but one is "the extent to which another state may have an interest in regulating the activity." Section $403(1)$ prohibits a state from exercising jurisdiction when it would be unreasonable. See also id. $\$ 403 \mathrm{cmt}$. a.

If one takes a sociological approach to questions of international law, as I do, whether practices of restraint in such situations of conflicting interest, typically attributed to comity, do or do not constitute rules of international law appears a rather sterile debate. Under such an approach, one would ask whether there exists an expectation on the part of participants in the international legal system that nations should follow these practices and, if so, whether failure to follow them will result in any sanctions. See Myres S. McDougal \& Harold D. Lasswell, The Identification and Appraisal of Diverse Systems of Public Order, 53 AM. J. INTL. L. 1, 8 (1959). Even commentators who insist on the distinction between comity and law, such as Lauterpracht and Oppenheim, would answer both these questions affirmatively. They clearly view rules of comity as ongoing practices. The existence of an ongoing practice of restraint on the part of most states when confronted with certain situations of concurrent jurisdiction will certainly lead over time to the expectation that the practice should be followed. States which do not follow the practice are likely to be subject to a reciprocal lack of courtesy, a response suggested by the references to "neighborliness" in the traditional formulation of comity. Thus there are sanctions for failure to follow the practice.

82. See Mannington Mills, Inc. v. Congoleum Corp., 595 F.2d 1287 (3rd Cir. 1979); Tímberlane Lumber Co. v. Bank of America N.T. \& S.A., 549 F.2d 597 (9th Cir. 1976).

83. See RESTATEMENT, supra note 70, \& 403(2)-(3) 
These concerns correspond closely to the criteria suggested here for choosing the best approach to statutory reach: the approach's ability to enhance U.S. economic welfare generally - counting in the calculation of U.S. welfare the effect on the United States of the reaction of other countries - and, in particular, the approach's ability to discriminate between issuers whose disclosure behavior primarily affects U.S. welfare and issuers whose disclosure behavior primarily affects some other state. The economic analysis of the transnational distribution of the effects of issuer disclosure behavior undertaken in this Article demonstrates, according to these criteria, the superiority of the issuer nationality approach. Thus if the United States adopted this approach, it would clearly appear to be acting within the constraints imposed by international law.

\section{The Superiority of the Issuer Nationality Approach over the InVESTOR Residency ApProach}

In these next three Parts, I consider how the choice of approach affects U.S. economic welfare through the selection of which of the world's issuers will fall within the reach of the U.S. regime. The issuer nationality approach is clearly superior to the investor residency approach in this regard. The United States, it will be seen, has a strong interest in the disclosure behavior of all U.S. issuers. This includes even those whose shares are only publicly sold to or traded among foreign investors, the group reached by the issuer nationality approach but not by the investor residency approach. In contrast, the United States has at best only a subsidiary interest in the disclosure behavior of foreign issuers. This includes even those whose shares are publicly sold to or traded among U.S. residents, the group reached by the investor residency approach but not reached by the issuer nationality approach.

The issuer nationality approach is also clearly superior to the transaction location approach as well. No U.S. interest in determining the disclosure behavior of any issuer is affected by the country in which transactions in their shares takes place. The transaction location approach thus utilizes as its criterion for selecting issuers to which to apply U.S. law a factor wholly unrelated to U.S. interests. It would thereby arbitrarily cut out from U.S. application some issuers whose disclosure behavior is of strong interest to the United States - U.S. issuers whose shares are publicly sold or traded only abroad. In fact, it would create an incentive for U.S. issuers to put themselves in this group. At the same time, it would arbitrarily include others whose disclosure behavior is at most of subsidiary in- 
terest to the United States - foreign issuers whose shares are sold or traded in the United States. Furthermore, it will diminish the volume of transactions effected in the United States.

Nationally based regulation utilizing the issuer nationality approach is, it will be seen, also superior to any achievable uniform international regime.

There is an implicit assumption behind the normative conclusions that issuer nationality is superior to the other two approaches or any achievable international disclosure regime. This is the assumption that for entirely domestic U.S. issuers - those whose entrepreneurs, operations, and shareholders exist exclusively in the U.S. and whose shares are exclusively sold or traded there - the U.S. regime's current required disclosure level is closer to what would maximize U.S. economic welfare than is the required disclosure level of any other country's regime. This assumption is extensively explored in Part VII. Its use at this point, however, is sufficiently justified by the observation that compared to foreign officials, U.S. officials have greater expertise about the tradeoff between the costs and benefits of the disclosure behavior of entirely domestic U.S. issuers and are the officials politically responsible to the persons most affected by such behavior. These three parts can therefore be seen as identifying for which of the world's other issuers U.S. officials are similarly the superior regulators. The answer is that U.S. officials are the best regulators for all remaining U.S. issuers - those that are not entirely domestic - and no foreign issuers.

The argument is laid out as follows. In Part III, I show why applying the U.S. regime to the set of issuers selected under the issuer nationality approach enhances U.S. economic welfare more than would applying the U.S. regime to the set of issuers selected under the investor residency approach. This is so even if other countries do not adopt the same approach. ${ }^{84}$ In Part IV, I show

84. This recommendation involves identification of policies that are in the economic longterm best interests of the United States and is not intended to address what policy constitutes the best strategic bargaining position in the short term. In this regard, there is a parallel between the policy recommended here and the policy, recommended by classical trade theory adherents, that the United States is better off engaging in free trade even if other countries do not. See Richard E. Caves \& Ronald W. Jones, World Trade and Payments: An InTroduction 12-19 (1985). In both the disciosure regulation case and the trade one. the United States would be even better off if other countries too adopted the recommended policy, and the other countries would be worse off if the United States does not. Therefore. strategic bargaining considerations may call for the United States temporarily not to adopt the recommended policy - even though adopting it would make the United States better off - in order to pressure the other countries to act in a way - adoption of the recommended approach - that would make the United States even better off than it would be by adopting the policy alone. 
why the issuer nationality approach has the same superiority compared to the transaction location approach. In Part V, I show why adopting the issuer nationality approach enhances U.S. welfare more than adopting any achievable international regime. In all three Parts, I assume that the choice of approach will have no effect on the level of disclosure required by the U.S. regime. The implications of relaxing this assumption will be explored in Parts VI and VIII.

\section{A. The United States Has a Strong Interest in Determining the Disclosure Behavior of U.S. Issuers Even When Their Shares Are Publicly Sold to and Traded Among Only Foreign Investors}

\section{The Basis of the U.S. Interest}

Greater disclosure can, through its positive effects on managerial motivation and the choice of real investment projects, increase the returns generated by capital-utilizing productive activity. ${ }^{85}$ Three groups share in the overall returns generated by such activity: the public suppliers of capital, the original suppliers of entrepreneurial talent, and the suppliers of the other factors of production - primarily labor. Publicly supplied capital, however, is much more mobile transnationally than entrepreneurial talent or labor. As a result, competitive forces push capital toward receiving a single global expected rate of return (adjusted for risk) regardless of the disclosure practices of the particular issuers involved. ${ }^{86}$ The

85. The benefits of greater issuer disclosure are discussed infra in section III.D.1.b.i.

86. According to the efficient market hypothesis, the price at which an issuer's shares trade will be unbiased whether there is a great deal of information available about the issuer or very little. By "unbiased," I mean that the price is on average equal to the share's actual value, i.e., what the future income stream accruing to the holder of the share - its dividends and other distributions - turns out to be, discounted to present value. Speculators - the persons whose actions in the market set prices - assess what this future income stream will be based not only on what information is available about the issuer but also on what is not. The empirical literature testing the efficient market hypothesis suggests that the inferences that speculators draw from issuer disclosures are in fact unbiased. Since there is no reason to believe that their inferences from issuer absences of comment are any more likely to be biased than their inferences from issuer disclosures, this literature suggests as well that the inferences they draw from issuer absences of comment are also unbiased. I discuss these points in considerably more detail elsewhere. See Fox, Disclosure in a Globalizing Market, supra note 1, at 2533-39. If share prices are unbiased and the world's investors have a global set of issuers to choose from, each investor will receive the same risk-adjusted expected rate of return whatever issuer's shares she purchases, whether the issuer discloses at a high level or a low one. Professors Choi and Guzman and Professor Romano agree. They suggest that an issuer's share price will reflect a market discount for the applicable disclosure regime. See Choi \& Guzman, Dangerous Extraterritoriality, supra note 9. at 220-21: Romano, supra note 15 , at 2366.

The efficient market hypothesis has been attacked by adherents of noise theory. The noise theorists believe that share prices are affected by the irrational expectations of naive 
increase in returns resulting from greater issuer disclosure therefore largely accrues to the latter two groups. ${ }^{87}$

A typical issuer, even if labeled "multinational," will still have a distinct nationality, an identifiable economic center of gravity in a single country where its original entrepreneurial talent and the largest portion of its management and workers are concentrated. ${ }^{88}$ Thus most of the gains from greater disclosure will be enjoyed in an issuer's home country, regardless of where in the world its public shareholders reside.

Greater disclosure also has costs that must be weighed against its capacity to increase the returns generated by capital utilizing activity. Again, because of capital's greater mobility, the costs of disclosure, too, will fall largely on the latter two groups.

Thus the gains and costs of the disclosure behavior of U.S. issuers are concentrated among U.S. residents. U.S. economic welfare is maximized when the level of disclosure for issuers of U.S. nation-

speculative traders, who are activated by fads, fashions. and irrational psychological predispositions. See, e.g., Fischer Black, Noise, 41 J. Fin. 529 (1986). Since noise is as likely to cause prices to be too low as too high, the proposition that share prices on average equal actual value still holds even if the noise theorists' description of the world is correct. For a more extensive discussion of why noise theory does not undermine the argument that the issuer's home country has the greatest interest in its disclosure level, see Fox, Disclosure in a Globalizing Market, supra note 1, at 2536-37 \& n.76, 2555 n.103.

87. If a country's issuers represent only a small portion of all equities available to investors in the world, investors would share in none of these gains. The country would be analogous to a single small firm in a perfectly competitive industry. Such a firm's level of production has no effect on price. Following this analogy, what the country produces is investment opportunities - dollars of future expected cash flow - just like the firm produces products. A disclosure improvement's positive effects on managerial motivation and choice of real investment projects will increase the number of dollars of future expected cash flow that the country's issuers have to sell. This benefits both the entrepreneurs, who are selling the cash flow, and labor, who gain from the overall increase in the country's economic efficiency. See Fox, Disclosure in a Globalizing Market, supra note 1, at 2561-69. Because the country is like a small firm, however, the increase in the amount supplied is not great enough to lower the price at which a dollar of future expected cash flow is sold. Thus there is no benefit to investors, the "buyers" of these dollars of expected future cash flow.

If a country's issuers represent a substantial portion of all equities available to investors in the world, as is the case with the United States, investors will share in some of these gains. A disclosure improvement's increase in the number of dollars of future expected cash flow that the country has to offer would be great enough to lower the price at which a dollar of future expected cash flow is sold, at least slightly. Thus investors would gain from the improvement. This is equally true of foreign investors as U.S. investors, however, and foreign investors own almost two-thirds of all the shares of publicly traded issuers in the world. See id. at $2525 \mathrm{n} .51$. Moreover, it is equally true of disclosure improvements of U.S. issuers whose shares are primarily sold to, or traded among, only foreign investors as it is of U.S. issuers with primarily U.S. shareholders.

88. In 1990, profits from foreign operations of U.S. corporations amounted to only about one-sixth of all corporate protits. See 72 Surv. Current Bus., Dec. 1992, at 14 (NIPA Table 6.16 c). In 1989, overseas assets of even U.S. corporations designated as "multinational" were only about one-fifth of their total assets. See J. Lowe \& R. Mataloni, Jr., U.S. Direct Investment Abroad: 1989 Benchmark Survey Results, 71 Surv. Current Bus. Oct. 1991, at 29 (data from Table 1). 
ality, wherever their shareholders reside, is set at the point where the marginal social costs of additional disclosure equals the marginal increase in returns generated by that disclosure. ${ }^{89}$

Market forces are not likely to lead firms to disclose at a level this high, ${ }^{90}$ hence the need for a government to consider regulation. ${ }^{91}$ The question for this study is which government. The beneficiaries when U.S. issuers disclose at the socially optimal level their entrepreneurs and workers - are concentrated in the United States and U.S. officials have the greatest familiarity with U.S. firm governance structures. U.S. officials, therefore, have both greater motivation and greater expertise than do officials of any other country to decide whether disclosure regulation is called for and, if so, what the optimal level is. This is just as true of U.S. issuers whose shares are publicly sold to, or traded among, only foreign investors - issuers not reached by the investor residency approach - as it is of U.S. issuers with only U.S. shareholders. And the U.S. residents' stakes in the regulators getting the required level of disclosure right are equally great for both types of firms.

89. The proposition that the United States has a strong interest in the disclosure behavior of all U.S. issuers, regardless of where in the world their shareholders reside, holds whether or not the text's simplifying assumption of a single global expected rate of return on capital is correct. A country whose issuers disclose at the optimal level of disclosure will have capital utilizing enterprises that produce higher returns net of costs of disclosure. If the single rate assumption is correct, the gains from getting the disclosure level right will primarily be enjoyed by the less mobile claimants on these returns, domestic entrepreneurs and labor, not by the suppliers of capital, who, wherever in the world they live, will at best enjoy a slight increase in the overall global expected return on capital. See supra note 87 . If the assumption is incorrect, the reason would be that each country's investors still have a degree of bias against issuers from other countries. In that event, U.S. investors, for example, might share disproportionately in the gains from moving the U.S. issuer disclosure level toward its optimal level. The bias of foreign investors against U.S. issuers would mean that the increase in the number of expected dollars of future cash flow resulting from the change in required disclosure would be offered to a somewhat restricted market and push the price for them down more for U.S. investors than for other investors. See supra note 87 . To the extent that a U.S. issuer has U.S. shareholders, the fact that U.S. investors will share disproportionately in the gains from optimal disclosure simply creates an additional U.S. interest in the level of the issuer's disclosure. As for U.S. issuers whose shares are sold to and traded among only foreign investors, entrepreneurs and labor in the United States would, just as if there were a single global expected rate of return on capital, enjoy most of the gains from optimal disclosure. See Fox, Disclosure in a Globalizing Market, supra note 1, at 2561-69. Thus, the United States interest in the disclosure behavior of this second set of issuers would be as strong as it is shown to be under the assumption in the text.

90. This market failure is discussed extensively infra in section IV.A.2.

91. After consideration, a government might conclude that despite this market failure, disclosure regulation would nevertheless on balance be undesirable. Again, the question is, for any given issuer, which government should decide this question. 


\section{Foreign Relations}

The conclusion that it is in the best interests of the United States to extend the reach of its regime even to U.S. issuers whose shares are only publicly sold to or traded among foreign investors is not a parochial one that ignores U.S. foreign relations. Extending the statute's reach in this fashion would not threaten the legitimate interests of any other country. Foreign shareholders of U.S. issuers will receive the same global expected rate of return (adjusted for risk) regardless of the level at which U.S. issuers disclose ${ }^{92}$ and so foreign concerns about U.S. issuer expected returns cannot form a sound basis for objections to U.S. regulation. It is U.S. residents, not those of any other country, who enjoy the increased project returns from greater disclosure by U.S. issuers and who pay its extra cost.

For less than fully diversified foreign investors, the risk in holding shares in U.S. issuers is affected by these issuers' level of disclosure. $^{93}$ The U.S. regime's level of disclosure, however, has a positive effect on the welfare of these investors. The U.S. regime is the most rigorous in the world, ${ }^{94}$ and so its imposition is a cost-free benefit to these foreign investors. Thus, effect on risk is also not a sound basis for a foreign country to complain about the United States applying its regime to U.S. issuers whose shares are sold to or traded among the foreign country's investors.

92. See supra note 84 and accompanying text.

93. While the amount of information available in the public domain about an issuer does not affect the proposition that the issuer's share price will be unbiased, see supra note 89 and accompanying text, it is related to the accuracy of the issuer's share price. A share price can be unbiased - no more likely to be above than below the share's actual value — but still have a low expected accuracy in the sense that there is a significant likelihood that there is a substantial difference one way or the other between the price and actual value.

With less information about a U.S. issuer, speculators will have greater uncertainty about its future and, as a consequence, the issuer's shares will have lower expected price accuracy. Put another way, with less information the issuer's shares will have greater total risk associated with them because there is a greater likelihood that what an investor receives from holding such a share - distributions and price at resale (both discounted to present value) will deviate substantially, one way or the other, from what she pays for it. This increased risk means that any investor holding shares of the issuer, unless she is fully diversified (by also holding shares of a substantial number of other issuers) will have a more risky portfolio than would have been the case if more information were available about the issuer. Some portion of all the foreign buyers of the U.S. issuer's shares will in fact be less than fully diversified and consequently, with lower disclosure, suffer lower expected utility - assuming, as the capital asset pricing model suggests, that the issuer's shares will be priced in such a fashion that its expected return is unaffected by the greater company specific risk resulting from a low level of disclosure. Again, I have considered these points in more detail elsewhere. See Fox, Disclosure in a Globalizing Market, supra note 1, at 2540-44.

94. See infra notes 103 and 149. 
The only foreign groups who would be injured by extending U.S. disclosure requirements to U.S. issuers whose shares are sold to or traded among only foreign investors are those who profit from the volume of securities transactions effected in their home countries. With the issuer nationality approach, U.S. issuers will no longer have an incentive to evade U.S. disclosure rules by offering and promoting the trade of their shares abroad. Thus the proposed switch in approach would diminish the volume of U.S. issuer transactions in other countries. But this injury is not a legitimate basis for other countries to protest the proposed extension. Between countries, volume is a zero-sum game. It should be won or lost based on the cost and quality of the transactional services available in each country, not on the ability of one country to offer a way to evade regulations of another country aimed at behavior that primarily affects the welfare of residents of the country whose regulations are being evaded.

\section{B. The U.S. Has, at Best, Only a Weak Interest in Determining} the Disclosure Behavior of Foreign Issuers Even When Their Shares Are Publicly Sold to or Traded Among U.S. Investors

\section{The Basis of the Interest}

As shown by the discussion above, the expected rate of return that U.S. residents receive from investments in the shares of a foreign issuer will be capital's overall global expected rate of return (adjusted for risk). It will be largely unaffected by the issuer's level of disclosure. Thus, notwithstanding the traditional concern of the SEC and many commentators with investor protection, ${ }^{95}$ expected return considerations cannot constitute a serious basis for applying the U.S. disclosure regime to a foreign issuer. ${ }^{96}$

95. See supra notes 19-24.

96. See supra section III.A.1. If there were an overall improvement in disclosure in the sense that issuers around the world all moved closer to their respective optimal levels of disclosure, investors would share in some of the resulting gains. This is because the increase in the number of dollars of future expected cash flow offered to the global market of investors would lower the price at which a dollar of future expected cash flow is sold. See supra note 87 . This fact, however, does not create a special U.S. stake in the disclosure behavior of foreign issuers. To start, foreign investors would enjoy this decrease in the price of a dollar of expected cash flow as much as would U.S. investors, and foreign investors own almost twothirds of all the shares of publicly traded issuers in the world. See Fox, Disclosure in a Globalizing Market, supra note 1, at $2525 \mathrm{n} .51$. Moreover, for reasons parallel to those set out in section III.A.1 concerning the strong U.S. interest in the disclosure of U.S. issuers, each other country does have a special stake in the disclosure behavior of its issuers because of the effect of such disclosure on entrepreneurs and labor concentrated in its country. Officials of each other country also have superior expertise on what would be the socially optimal disclosure level for its issuers, which is likely to differ substantially from one country to the next. See infra sections V.A and V.B. This creates a presumption that extending the U.S. 
Greater disclosure will benefit less than fully diversified U.S. investors holding such shares by reducing the unsystematic risk in their portfolios. ${ }^{97}$ This potential for reducing U.S. investors' risk is, however, the basis for only, at best, a weak U.S. interest in applying its regime to foreign issuers. Unlike the benefits U.S. residents realize from greater issuer disclosure by U.S. issuers (discussed just above), greater disclosure by foreign issuers provides benefits to U.S. residents achievable in other ways. There is no obvious alternative for achieving the benefits to U.S. residents from greater U.S. issuer disclosure - the increased returns to capital utilizing activities from more accurate price induced better project choice and improved managerial motivation. In contrast, the benefit from foreign issuer disclosure - the reduction of unsystematic risk - can be achieved by another strategy: a program of educational and institutional reform that will encourage U.S. investors to diversify. If an investor is fully diversified, the greater unsystematic risk associated with her having in her portfolio shares of a foreign issuer that discloses less than the U.S. level will not have a negative impact on her welfare. Given the availability of this alternative strategy, the U.S. ability to regulate foreign issuer disclosure is less vital.

\section{Countervailing Domestic Considerations}

Furthermore, the full effect on U.S. investor welfare of imposing the U.S. regime on foreign issuers cannot be ascertained by considering its risk reduction impact in isolation. Investors are made better off when shares of additional issuers are made available, even if

regime to these issuers would move their disclosure away from, not toward, the optimal level for them.

The proposition in the text again does not depend on the text's simplifying assumption of a single global expected rate of return on capital. If the assumption is incorrect the reason would be that each country's investors still have a substantial degree of bias in favor of their country's issuers. See supra note 89 . That means that the impact of improved foreign issuer disclosure on U.S. investors will be even smaller. The increased supply of expected future dollars would lower their price less for U.S. investors since U.S. investors are buyers in a market that behaves, because of the bias, as if the availability of this increased supply were partially restricted.

A special situation exists with Canada. U.S. investors feel significantly more comfortable purchasing shares of Canadian issuers than purchasing shares of other foreign issuers, and the United States has a much larger pool of investors than does Canada. This, however. suggests a situation of sufficiently intense interaction between these two economies that disclosure regulation would, and as a practical matter can. best be handled by bilateral agreements establishing a joint regime, rather than by general rules parceling out authority between the two countries as to which national regime should govern. The United States and Canada are working toward such an arrangement by undertaking a degree of coordination of their two regimes and then providing for reciprocal recognition for qualified issuers that register under the other country's regime. See supra notes 21, 24.

97. See supra note 93 and accompanying text. 
these additional issuers only disclose at a very low level.98 If the U.S. policy imposes its regime on all foreign issuers whose shares are publicly sold to or traded among U.S. investors, many foreign issuers will seek to avoid the U.S. regime by making their shares unavailable to U.S. investors. The loss in U.S. investor utility from reduced availability of foreign issuers' shares may be greater than the gain in investor utility from the increased disclosure by the foreign issuers that do make their shares available. U.S. investors can therefore actually be made worse off if the U.S. regime is applied to foreign issuers.

\section{Foreign Relations}

When U.S. foreign relations are taken into account, the U.S. interest in applying its regime to foreign issuers becomes even more problematic. Imposition of the U.S. regime requires the issuer to disclose more than officials in the issuer's own country have determined is cost effective. At least in the eyes of these foreign officials, the higher level of disclosure required by the United States costs more than it is worth and thus reduces the net returns to capital utilizing productive activities in their own country. The imposition of the U.S. regime damages the issuer country's entrepreneurs, suppliers of labor, and, if the issuer has previously gone public at home, suppliers of capital.

This foreign relations problem is going to be severely exacerbated by the growing globalization of financial information and the declining difficulty and expense of effecting share transactions abroad. There will be increasingly large numbers of foreign issuers whose shares will be publicly sold to and traded among U.S. investors. Under the investor residency approach, the U.S. regime would thus apply to foreign issuers with greater and greater frequency. Each additional application is objectionable to the issuer's home country since its residents suffer the welfare loss when the issuer discloses more than is socially optimal. This is particularly so since the U.S. regime is imposed to cure the purely domestic U.S. problem of inadequate investor diversification.

98. Whatever level of disclosure is imposed on the issuer, each additional investment opportunity available to investors that a share value maximizing firm finds worth selling into a market with unbiased pricing represents an increase in demand for savings. It therefore marginally raises the overall market expected rate of return available to investors. Also, each additional investment opportunity has a future return generated by a probability distribution with somewhat different variance-covariance characteristics than any existing opportunity and therefore permits investors to compose portfolios with more favorable tradeoffs between risk and return than otherwise would have been available. For a more formal elaboration of these points, see Fox, Disclosure in a Globalizing Market, supra note 1, at 2542-44. 
This foreign relations problem is not ameliorated in any rational way by making a distinction between foreign issuers that take voluntary steps to make their shares available to U.S. investors, for example by listing them on a U.S. stock exchange, and those that have done nothing to promote the availability of their shares. ${ }^{99}$ The investor protection rationale calls just as strongly for application of the U.S. regime to both, since the impact of low disclosure on the riskiness of the portfolios of less than fully diversified investors is the same whether or not the issuer has promoted its shares' availability. And the imposition of the U.S. regime should be equally unpalatable to the foreign issuer's country in either case. The fact that a foreign issuer voluntarily takes steps to promote U.S. availability may rhetorically strengthen the argument for imposing the U.S. regime, but it does not strengthen the argument on substantive economic grounds. The taking of voluntary steps does not affect the strong presumption that an issuer's home country requirements are closer to the issuer's particular socially optimal disclosure level than are the U.S. requirements. It simply means that the issuer's gains from having a U.S. market for its shares exceed the extra costs, not that the extra costs are justified. Thus, whether or not a foreign issuer has done anything affirmative to promote the availability of its shares to U.S. investors, it is objectionable to the issuer's home country that its residents suffer a welfare loss from the issuer disclosing more than what its government believes is socially optimal.

\section{Qualifications for IPOs and Foreign Issuers Trading in Immature Markets}

The recommended switch to the issuer nationality approach should be qualified in the case of an initial public offering (IPO) by a previously privately held foreign company. There is an extensive literature about the pricing of U.S. issuer IPOs in the United States,

99. The SEC has long held to the principle that a distinction should be made between foreign issuers that voluntarily enter the United States securities markets and those whose securities are traded in the U.S. market without their encouragement. See, e.g., Release No. 6360 , supra note 44 , at 58,512 . This principle is at least partially refiected in practice - for example, the distinction for Exchange Act periodic disclosure purposes between foreign issuers whose shares are listed on a U.S. exchange or NASDAQ and issuers whose shares are not. see supra notes 37-44 and accompanying text, and the distinction for Securities Act new offering disclosure between foreign issuers that engage in selling efforts directed at the United States and those that do not, see supra notes 21-24 and accompanying text.

While, as argued in the text, such distinctions do not in any rational way reduce the damage to other countries from an investor protection approach, they do keep the United States on stronger ground in terms of making the formal claim of prima facie jurisdiction to prescribe. See supra section II.C.1.b. 


\section{some of which suggests that shares purchased in such offerings are priced inefficiently high. ${ }^{100}$ Certainly the mechanisms needed to}

100. A large number of studies show that initial public offerings (IPOs) are offered at a "discount" in the sense that there is on average a significant jump from the offering price to the price at which the shares trade in the initial days or weeks after the offering. See James R. Booth \& Lena Chua, Ownership dispersion, costly information, and IPO underpricing, 41 J. FIN. ECON. 291, 306-07 (1995) (surveying empirical studies establishing the discount and testing possible explanations); Roger G. Ibbotson et al. Initial Public Offerings, $1 \mathrm{~J}$. APPLIED Corp. FIN. 37 (1988) (similar survey); Roger G. Ibbotson \& Jay R. Ritter, Initial Public Offerings, in North-Holiand Handbooks of Operations Research and Management SCIENCE: FINANCE (R.A. Jarrow et al. eds., 1992) (showing underpricing in other countries).

The fact that on average IPO prices are discounted relative to the prices at which the shares initially trade does not necessarily mean, however, that they are discounted relative to their actual value. The studies are more mixed on this latter question. Ibbotson, in perhaps the most frequently cited study establishing the existence of the discount relative to initial trading price, looked as well at prices thereafter for various periods up to five years and found returns on a risk adjusted basis were normal, thereby suggesting that the initial trading price was efficient and that the offering price was discounted relative to actual value. See Roger G. Ibbotson, Price Performance of Common Stock New Issues, 2 J. FIN. Econ. 235, 250-58, 265; see also Seha M. Tinic, Anatomy of Initial Public Offerings of Common Stock, 43 J. FIN. 789, 815 (1988). Loughran and Ritter recently came to a different conclusion. In a study that matched a large number of firms doing IPOs with comparable firms that were already publicly traded and had made no offering in several years, they found that it would on average require a $44 \%$ larger investment in the IPO at its initial trading price to end up with the same wealth five years later as with investing in the non-offering matching firm. See Tim Loughran \& Jay R. Ritter, The New Issues Puzzle, 50 J. Frv. 23, 32 (1995). This inferior return swamped the initial discount of the offering price relative to the initial trading price so that one would still have to make a $30 \%$ larger investment in the IPO at the offering price to end up with as much wealth in five years. See id. The Loughran and Ritter study thus suggests that relative to actual value, IPOs are not offered at a discount but at a large premium. See id:; see also Hans R. Stoll \& Anthony J. Curley, Small Business and the New Issues Market for Equities, 5 J. Fin. \& Quanttiative Analysis 309 (1970). Stoll and Curley studied issuers registering very small offerings under the SEC's Regulation A - at the time $\$ 300,000$ or less - and found that the offering prices were on average discounted relative to initial trading prices, but that over the longer run, investments in these shares at the offering price underperformed, even without risk adjustment, a portfolio of larger stocks. See id; see also George Stigler. Comment, 37 J. Bus. 414, 421 (1964). Stigler compares, for new issues of fered in the periods 1923-1927 (before the Securities Act) and 1949-1955 (after passage of the Act), the average ratio of the price of the new issue shares five years after an offering to market prices generally. He finds that the ratio for the post-Act period is not statistically significantly better than for the pre-Act period. He uses this result to argue that the Act led to no improvements. He also finds. however, without comment or a test for statistical significance, that in both periods the new issues, five years out, had underperformed the market as a whole, again even without risk adjustment.

The possibility, raised by these studies, that IPOs are offered at prices in excess of actual value suggests the existence of a market inefficiency that is systematically working to the advantage of issuers and to the disadvantage of investors. Without a better understanding of why such an inefficiency has arisen. if in fact it has, and why the market has not realized it and corrected for it, we cannot tell whether the level of disclosure affects the extent of the problem and, if so, which way. It must also be kept in mind that these findings may represent the pricing of an as yet unidentified risk factor that is less prevalent with firms offering new issues than with comparable ones that do not, rather than an unfairness-creating market inefficiency. In addition, for the last three years of the Loughran and Ritter study (1988-1990), the wealth shortfall from investing in new issues disappears. This could be consistent with the market having "caught on" and corrected for the inefficiency, although the authors feel that given the particular features of these three years, this period is too short to reach such a conclusion. See Loughran \& Ritter, supra, at 49 . In sum, the studies are simply reason for more caution in changing IPO disclosure policy than other disclosure policies. 
generate price efficiency in the market for IPOs are more complicated, and their existence less well established empirically, than the mechanisms that appear to generate price efficiency in secondary markets. Caution, therefore, may suggest that contrary to the general recommendation here, the United States should not, at least initially, switch to the issuer nationality approach in the case of foreign issuer IPOs. On the other hand, a new share offering by an established public foreign issuer does not involve the same problems since the offering's price will be determined primarily by the prevailing price in the secondary market for the issuer's already outstanding shares. Like the secondary market in the United States, the secondary market abroad for this issuer's shares can be assumed efficient, at least in the case of other developed capitalist economies. ${ }^{101}$

The recommended switch to the issuer nationality approach should also be qualified for both new issue and periodic disclosure in the case of foreign issuers whose shares trade primarily in the more immature secondary markets found in developing countries and newly emerging economies. While there is evidence that many foreign secondary markets display the same kind of efficiency that U.S. ones do, the testing of this proposition, especially with respect to markets outside Europe, is certainly not as extensive as with U.S. markets. ${ }^{102}$ We cannot be sure that the more immature markets found in developing countries and newly emerging economies have the same level of efficiency as markets in the United States and Europe. Moreover, the mechanisms that appear to generate price efficiency in the United States and Europe are not as firmly in place in such markets. Caution again suggests that at least initially the issuer nationality approach not be extended to these issuers.

101. See Gabriel Hawawini, European Equity Markets: A Review of the Evidence on Price Behavior and Efficiency, in European Equity Markets 3 (Gabriel A. Hawawini \& Pierre A. Michel eds., 1984); see also William J. Baumol \& Burton G. Malkiel. Redundant Regulation of Foreign Security Trading and U.S. Competitiveness, in KENNETH LEHN \& Robert Kamphuis Jr., Modernizing U.S. Securities Regulation 35 -51 (1992) (collecting studies showing the efficiency of a variety of foreign secondary markets).

102. See Baumol \& Malkiel, supra note 101. 


\section{The Analysis of U.S. Interests Does Not Depend on Other Countries Also Adopting the Issuer Nationality Approach}

\section{Why There Is No Need for the Foreign Issuer's Home Country to Switch}

My analysis above still holds true even if other countries continue to adhere to the investor residency approach to statutory reach. Consider first the proposition that the U.S. has a strong interest in applying its regime to all U.S. issuers, including those whose shares are only publicly sold to, or traded among, foreign investors. The whole argument in support of this proposition is based on the idea that there is an optimal level of disclosure for such an issuer and that U.S. officials have both greater motivation and greater expertise than do officials of any other country in ascertaining what that optimal level is. When the United States, in accordance with the issuer nationality approach, imposes its regime on a U.S. issuer, the issuer will in fact be disclosing at what in the U.S. judgment is the optimal level, whatever any other country does. If another country, in continued adherence to the investor residency approach, imposes its regime on the U.S. issuer as well, there is unlikely to be a material effect on the issuer's disclosure behavior since the U.S. disclosure requirements, with which the issuer is already complying, are the most comprehensive in the world. ${ }^{103}$

103. This statement reflects a reasonable approximation of reality. See generally Michael. Bowe. Eurobonds 115 (1988) ("[T]he US has what are generally considered to be the most extensive disclosure and regulatory requirements of any major capital market."); Frederick G. Fischer III, The Eurodollar Bond Market 86 (1979) (describing the SEC's registration requirements as involving "a degree of disclosure of both the issuer"s business and its financial position, well beyond what is customary in the Euromarkets"): see also infra note 149. For imposition of the foreign regime to have absolutely no effect, all the information required by the foreign regime must be a subset of what is required by the U.S. regime. This condition that the U.S. and foreign regime be in a linear relationship is not literally satisfied. While most of the information sought by the foreign regime typically would be information sought by the U.S. regime, it might need to be presented in a somewhat different form. And some of the information sought by the foreign regime would in fact not be sought by the U.S. regime. Thus if the foreign regime as well as the U.S. regime is imposed on a U.S. issuer, the issuer will be forced to disclose more than what the U.S. calculation of costs and benefits would deem justified.

Nevertheless, linearity is an acceptable working assumption. Most U.S. issuers that are already subject to the U.S. regime and decide to sell securities in the Eurobond or Euroequity market find that preparation of the necessary disclosure documents for the foreign authorities largely involves a simple markup of their U.S. disclosure documents. See, e.g., Accounting for Global Stocks, THE Exchange, Jan. 1996, at 6 ("American companies listing in overseas markets rarely have to make major adjustments in their reporting because other countries usually accept it as satisfying their requirements."). Foreign country officials are aware of the greater rigor of the U.S. regime. They have motivations to be flexible about what is required of U.S. issuers so as not to put impediments in the way of having U.S. issuers 
The second proposition - that the U.S. has at best only a weak interest in applying its regime to foreign issuers whose shares are publicly sold to or traded among U.S. residents - also does not depend on other countries adopting the issuer nationality approach. Consider the bases of the argument supporting this second proposition: that a foreign issuer's level of disclosure will not affect the expected return available to U.S. investors; that greater disclosure's risk reduction can also be achieved through greater investor diversification; that applying the U.S. regime to foreign issuers may on balance actually hurt U.S. investors by reducing the number of foreign issuers whose shares are available to them; and that applying the U.S. regime to foreign issuers may harm U.S. relationships with other countries by forcing their issuers to disclose more than their home countries believe is optimal. Each of these is true even if the foreign issuers are not subject to the disclosure regimes of their home country and is certainly unrelated to whether the foreign country imposes its regime on U.S. issuers.

\section{Qualifications}

Two qualifications are in order here as well. First, while diversification is more potent than imposition of the U.S. regime for reducing the risk to U.S. investors associated with holding a foreign issuer's shares (and this is true whether or not the issuer is subject to its home country's disclosure regime), some U.S. investors, either not understanding this fact or choosing to ignore it, will still not fully diversify. These investors will suffer a greater increase in risk if the U.S. stops applying its regime even to issuers not subject to their home country regimes, than they will if it stops applying its regime only to those that are still subject to their home country regimes. Where the issuer is not subject to the home country regime, the U.S. switch from the investor residency to the issuer nationality approach means a switch from a higher level of mandated disclosure to none, rather than from a higher level to a lower one.

The second qualification is that while another country may resent application of the U.S. regime to those of its issuers that are complying with its own regime, it may appreciate the application of the U.S. regime to those that are not. The resentment where the issuers are complying with the home country regime is based on its

shares offered to, and traded among, their residents. They do not want such impediments because, if their actions do keep such shares out of their country"s market. their investors lose additional investment opportunities and their securities industry loses business. See Choi \& Guzman, Dangerous Extraterritoriality, supra note 9, at 238-39. 
issuers being forced to disclose at a higher level than the home country has determined is cost effective. But where the issuers are not complying with the home country regime and the U.S. fails to apply its regime as well, the issuers are likely to be disclosing at a level lower than the home country officials would determine is cost effective in terms of home country welfare. The under-disclosure when the U.S. regime is not imposed may represent a greater deviation from what is optimal than the over-disclosure when the U.S. regime is imposed. Furthermore, officials of the other country might also be unhappy because imposing neither regime on foreign issuers whose shares are only offered and traded in the United States is likely to result in a loss of transactions in the home country. Its issuers will seek to evade its regime by promoting transactions in the U.S. instead. These concerns of foreign officials however, will be at most transitory for any country. The only time when foreign officials will be concerned about the under-disclosure and volume loss resulting from the United States not applying its regime would be when they understand the rationale behind the issuer nationality approach but are prevented from switching to it themselves by actors in the larger political environment who still adhere to an investor protection goal for mandatory disclosure.

These two qualifications suggest that the U.S., in adopting the issuer nationality approach, may wish to condition removal of U.S. disclosure requirements from foreign issuers on their compliance with the disclosure requirements of their home countries. Imposing this condition would not much alter the overall impact of the United States switching to the issuer nationality approach. As far as the Exchange Act periodic disclosure requirements are concerned, most foreign issuers, even from countries continuing to adhere to the investor residency approach, would meet this condition because there is a public market for their shares at home that would continue even if their shares started to trade in the United States. ${ }^{104}$ As far as Securities Act primary offering disclosure is concerned, although compliance with the home regime may not be compelled by an issuer's home country - for example in the case of an issuer from an investor residency country making a primary market public offering entirely abroad - presumably nothing stops the issuer from voluntarily submitting itself to the home country regime in order to avoid regulation under the more onerous U.S. regime. Also, I have already suggested that the issuer nationality approach

104. See infra note 172 . 
to statutory reach not be applied to foreign issuer IPOs, at least for now.

\section{The Superiority of the Issuer Nationality OVER the Transaction Location Approach}

The discussion so far has concluded that U.S. residents have a strong interest in the disclosure behavior of all U.S. issuers, even those with no U.S. investors, and at best only a weak interest in the disclosure behavior of all foreign issuers, even those with U.S. investors. These conclusions point to the superiority of the issuer nationality approach to statutory reach over the investor residency approach. We have yet, however, to evaluate the transaction location approach. While this approach plays a substantial role in current U.S. practice ${ }^{105}$ and some commentators believe it should play an even larger role, ${ }^{106}$ the analysis below suggests that its use is misguided.

The transaction location approach has three disadvantages compared to the issuer nationality approach. First, it imposes the U.S. regime on foreign issuers whose shares are offered or traded in the United States. The impact of this has already been fully discussed above. ${ }^{107}$ That analysis shows that U.S. residents have at most only a weak interest in the disclosure practices of foreign issuers. In fact, when we factor in the resulting reduction in the availability of foreign securities and foreign relations problems, the practice of imposing the U.S. regime on such foreign issuers will in all likelihood be contrary to U.S. interests.

Second, the transaction location approach removes some U.S. issuers from the reach of the U.S. regime. The analysis above shows that U.S. entrepreneurs and the U.S. resident suppliers of non-capital factors of production have a strong interest in the level at which each U.S. issuer discloses. Under the transaction location approach, a U.S. issuer's decision where to offer, sell, and promote trading of its shares will determine which country's disclosure regime governs its disclosure. The approach thus gives U.S. issuers a degree of control over the level at which they disclose. We will see

105. See supra Part II

106. The SEC, for example, in its release first proposing Regulation $\mathrm{S}$, advocated that "laws applicable in jurisdictions outside the United States [should] define disclosure requirements for transactions effected offshore." Initial Proposing Release, supra note 8, at 89,128. Similarly. Professor Choi and Guzman argue against what they refer to as the "extraterritorial" application of U.S. securities law including its disclosure rules. See Choi \& Guzman, Dangerous Extraterritoriality, supra note 9, at 221-23.

107. See supra section III.B. 
that they have incentives to choose regimes that require less disclosure than is in the best interests of these U.S. residents.

Finally, use of the transaction location approach negatively influences the volume of transactions effected in the United States. Issuers, in deciding whether to offer, sell, or promote trading of their shares in the United States, know that doing so would result in imposition of the U.S. regime, the strictest in the world, and many do not want this. Reduced volume will have a negative impact on the one group of U.S. residents whose interests we have not yet considered, persons directly or indirectly associated with the securities industry or securities exchanges, since their rents depend on this volume.

A. The Transaction Location Approach Gives U.S. Issuers Increasing Freedom to Choose Which Country's Regime Governs

Them and Their Preference Is for a Regime Requiring Less Disclosure Than Is Socially Optimal

1. The Issuer's Increasing Freedom to Choose Its Disclosure Regime

Under the transaction location approach to statutory reach, a U.S. issuer's choice of where to offer, sell, and promote the trading of its securities will determine the disclosure regime under which it operates. Admittedly, other factors also influence this choice besides its effect on what disclosure regime governs the issuer. Traditionally, for the typical U.S. issuer, U.S. residents have been their most likely potential investors. Moreover, U.S. residents have been significantly more likely to purchase shares that are offered and traded in the United States than those that are not. Combined, these two other factors have almost required such an issuer to have its shares offered and traded in the United States, however much the issuer is required to disclose as a result. The importance of these other factors is weakening, however. Financial information is becoming increasingly diffused globally, enlarging a U.S. issuer's pool of likely potential investors to include many foreigners. And the cost and difficulty of effecting orders abroad is going down, diminishing the bias of U.S. investors against shares not available in the U.S. market. As a result, a U.S. issuer's preference concerning its governing disclosure regime will, in the future, be of relatively greater importance in its choice of where to have its shares offered and traded than it is today. ${ }^{108}$

108. These changes are discussed in more detail infra in Part VI. 


\section{Market Failure: The Issuer's Preference for a Socially Suboptimal Disclosure Regime ${ }^{109}$}

An issuer's entrepreneurs or managers are the individuals who actually choose where an issuer's shares are offered, sold, and traded. Consequently, under a transaction location approach, they choose which country's disclosure regime applies. It is their preferences on which we must focus. Greater disclosure involves both added costs and added benefits to them. Their preference will be for the regime that requires the issuer to disclose closest to the level at which the marginal increase in cost to them (the issuer's private marginal cost or PMC) equals the marginal increase in benefit to them (the issuer's private marginal benefit or PMB). This point the issuer's "privately optimal level of disclosure" - will be below the issuer's socially optimal level of disclosure. This is because, as I show below, over the whole range of levels at which an issuer could disclose, the social marginal cost of the issuer's disclosure (SMC) is below its private marginal cost, and its social marginal benefit (SMB) is above its private marginal benefit (PMB). ${ }^{110}$ Thus, given the choice, the issuer's entrepreneurs or managers would prefer the issuer to be bound by a disclosure regime requiring less disclosure than is socially optimal.

109. I discuss the matters considered in this subsection more extensively in Fox Empowering Issuers, supra note 15.

110. Over this whole range both SMC and PMC are assumed to be increasing and SMB and PMB are assumed to be decreasing. This somewhat stylized model thus involves the issuer disclosure level being measured cardinally and having associated with it a rising marginal cost curve and a falling marginal benefit curve. This is a reasonable depiction of what in fact likely happens. The issuer first releases the piece of information that is most beneficial relative to its cost, then the piece of information that is next most beneficial relative to its cost, and so on. This corresponds to a situation where marginal private benefit is decreasing and marginal cost is increasing. Since there is no reason to believe that the differences between the marginal social benefit and marginal private benefit, or between the marginal social cost and marginal private cost, would increase substantially as an issuer discloses more, the marginal social benefit should also be decreasing and the marginal social cost should also be increasing. 


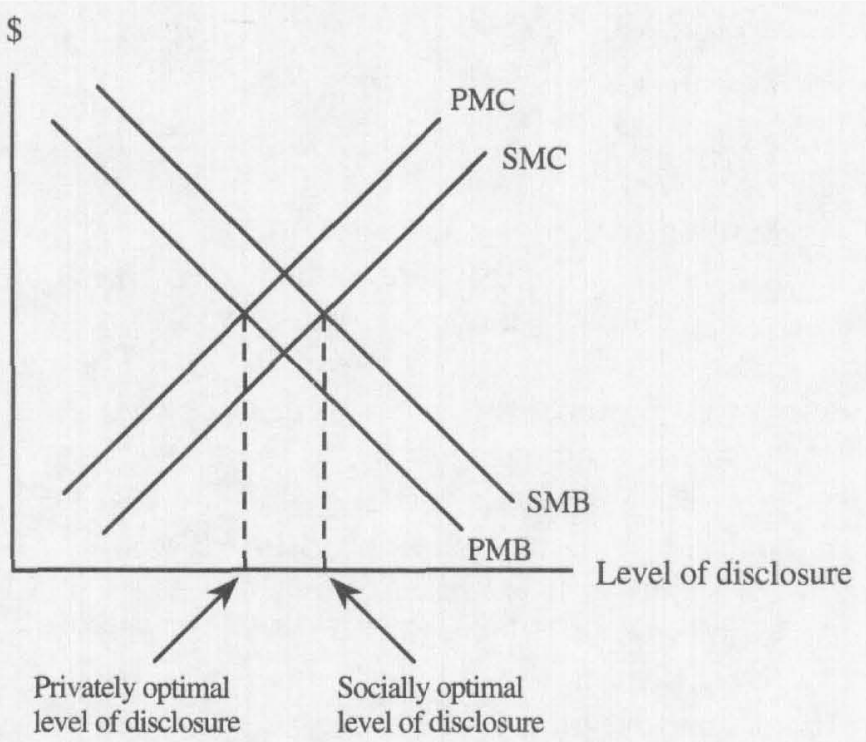

a. Costs. For each individual U.S. issuer, a disclosure involves two different kinds of costs, "operational" costs and "interfirm" costs. Operational costs are the out of pocket expenses and diversions of management and staff time that issuers suffer to provide the mandated information. Interfirm costs arise from the fact that the information provided can put the issuer at a disadvantage relative to its competitors, major suppliers, and major customers. ${ }^{111}$ Operational costs are both private and social costs. Interfirm costs are only private costs. They are not social costs because the interfirm disadvantages to the issuer from the disclosure are counterbalanced by the advantages it confers on the other firms. An issuer's private marginal cost will therefore exceed its social marginal cost at all levels of disclosure. ${ }^{112}$ Thus even managers who com-

111. A review of SEC Regulation $S-K$, which provides the questions that are incorporated by reference into its forms $10-\mathrm{K}$ (periodic disclosure) and $\mathrm{S}-1$ (initial public offering disclosure), shows that it calls for a wide variety of information the disclosure of which on the one hand would be useful for predicting an issuer's future cash flows, but on the other would hurt the issuer because of the advantages it confers on other firms. Examples include profits and sales of each significant individual line of business conducted by the issuer, future capital spending plans, research and development spending, cost ratios, liquidity constraints, and information on backlogs, inventories, and sources of supply. See, e.g., Regulation S-K, 17 CFR \$ 220.101(a)(2)(iii)(B)(2); \$ 220.101(c)(1)(vi); \$ 229.101(b); \$229.101(c)(1)(iii); $\$ 229.101$ (c)(1)(viii); \& 229.101(c)(1)(xi); \& 229.303(a)(1); \$229.303(a)(3)(ii) (1998).

112. See Lucian A. Bebchuk, Federalism and the Corporation: The Desirable Limits on State Competition in Corporate Law, 105 HARv. L. Rev. 1435, 1490-91 (1992); Coffee, supra note 10; Frank Easterbrook \& Daniel Fischel, Mandatory Disclosure and The Protection of Investors, 70 VA. L. REv. 669, 684-85 (1984); Edmund W. Kitch, The Theory and Practice of Securities Disclosure, 61 Brook. L. Rev. 763 (1995). 
pletely identify with existing shareholders - managers for whom costs to the shareholders are equivalent to costs to them - would, if they were free to choose the disclosure level at which to bind the issuer, choose a level below the social optimum.

This divergence between private cost and social cost becomes accentuated by the fact that disclosure increases the threat of a hostile tender offer if managers do not act to maximize share value. This is because more disclosure makes a takeover less risky for potential acquirors. ${ }^{113}$ This consequence of disclosure is not a cost to the issuer in terms of shareholder welfare; quite to the contrary. It is, however, a cost to an issuer's entrepreneurs or managers - its actual disclosure level decisionmakers - who would prefer to pursue their personal goals under fewer constraints. ${ }^{114}$

b. Benefits. The market failure associated with this divergence between social and marginal cost is compounded on the benefit side of the equation. The private marginal benefit associated with an issuer's disclosure will not equal its social marginal benefit unless (i) the social benefits of the level chosen are fully reflected in the issuer's share price, and (ii) this share price improvement is fully enjoyed by the persons making the choice - the issuer's entrepreneurs or managers. Under many circumstances one or both of these conditions will not be met and the private marginal benefit associated with an issuer's disclosure will be below the social marginal benefit.

Disclosure results in two major social benefits, improved choice of capital projects and reduced agency costs of management.

i. Improved project choice. How disclosure improves choice among proposed new investment projects in the economy can be seen most easily in a simplified world in which each new investment project is undertaken by a new issuer that raises the necessary funds through an IPO. Ideally, society would want to implement all pro-

Professor Romano. who favors a system under which issuers can choose the regime by which they are bound, dismisses the importance of this difference between private and social costs, suggesting that it is "a tenuous rationale for securities regulation." See Romano, supra note 15 , at 2426 .

113. See Merritt B. Fox, Finance and Industrial Performance in a Dynamic Economy: Theory, Practice, and Policy 84-91 (1987)

114. Greater managerial discipline would have a positive influence on share price. As my discussion of private benefits immediately below indicates, however, while this share price improvement may derivatively be enjoyed by the entrepreneur or managers, in many cases this benefit would not be sufficient to cancel out the cost to them of having to work under greater discipline. See infra section IV.2.b.iii. 
posed projects in rank order of their risk-adjusted expected returns - based on all available information including what is known by the entrepreneurs proposing each project. The marginal project that just exhausts society's scarce savings for investment would set the risk-adjusted expected return on capital. Whichever issuer's shares an investor purchased, she would receive a risk-adjusted expected return just equal to that of the marginal project.

This ideal will not be achieved in the real world because some of the information possessed by the entrepreneurs proposing each project will not be public and hence not reflected in share price. Some projects inferior to what in the ideal world is the marginal project will be implemented because their issuers' share prices are inaccurately high. Likewise, some projects superior to the ideal world's marginal project will not be implemented because their issuers' share prices are inaccurately low. With these projects, a public offering of even all of the issuer's equity would not produce sufficient cash to fund the project.

An increase by all issuers in their disclosure would increase the accuracy of all of their prices. The resulting reduction in the number of such misallocations would be a social gain. The question for us, however, is what kind of incentives exist for the entrepreneurs of each individual issuer to produce the disclosure that is needed to achieve this social gain. In essence, to what extent is the social gain produced by a single issuer's increased disclosure reflected in its share price?

If we were to pick one issuer at random and command an increase in the amount of disclosure it provides, its entrepreneurs would not on average enjoy any perceptible gain. Its share price without the increased disclosure would be an unbiased estimate of the future cash returns to the shareholder and so would the share price with the increased disclosure. ${ }^{115}$ If, however, we were to observe an issuer self-selecting to provide more disclosure than other issuers provide, we would expect the issuer's share price to go up and its entrepreneurs to enjoy a greater entrepreneurial surplus. Market participants would reason that because the issuer's entrepreneurs choose to reveal more, the issuer probably has better prospects relative to issuers disclosing less.

Thus it is the fact that an issuer chooses to disclose, not disclosure itself, that leads to the association between greater disclosure

115. The issuer's increased disclosure may result in better capital allocation and hence influence the overall expected rate of return on capital at which this cash flow is discounted, but in a large economy with many proposed projects this price effect would be imperceptible. 
and higher share price. This concept is the basis of signaling theory: issuers that have good news signal this fact by disclosing their news and those that do not have good news signal this fact by their inability to make comparable disclosures. ${ }^{116}$

While the signaling phenomenon means that the market will be better informed in a system of voluntary disclosure than might first appear, it will not be as well informed as if all issuers were compelled to disclose at the higher level that some issuers choose voluntarily. Silence is not a complete substitute for disclosure because the market knows that there are reasons why an issuer will not disclose besides lack of good news. ${ }^{117}$ As we have seen, an issuer may choose not to disclose because revealing the information might put it in an inferior position vis á vis competitor, major supplier, or major customer.

Projects therefore are not as well chosen in a signaling world where issuers are free to disclose or not and the market draws inferences from the decision of the issuers that do not - as in a world where all issuers disclose at a high level. Moving from the first world to the second produces social benefits because the list of projects implemented would be closer to the ideal. The entrepreneurs that do not disclose at a high level in the first world would not, through higher prices, fully capture these social benefits from their increased disclosure in the second world. Part of the benefits would instead accrue to the entrepreneurs who disclose at a high level in both worlds, because the improved allocation of capital would mean a higher percentage of their projects would be implemented. In essence, to price each IPO properly, the market needs information about all potential projects so that it can make the relevant comparisons accurately.

This public-goods aspect of issuer disclosure does not end here. There are other ways in which information disclosed by one issuer about itself can be useful in analyzing other issuers. It could, for example, reveal something about possible industry-wide trends. ${ }^{118}$ Again, these are social benefits that the issuer disclosing the information cannot appropriate through higher share price.

116. Signaling theory is the theory of self-induced disclosure in the context of an IPO. No one has offered any other plausible argument as to why voluntary disclosure alone could be sufficient. The classic statement of signaling theory is found in Ross, supra note 10.

117. See Easterbrook \& Fischel, supra note 112, at 687-88.

118. See id. at 685 . 
ii. Reduced agency costs of management. A second benefit of issuer disclosure is a reduction in the extent to which managers of public corporations place their own interests above those of their shareholders. Here I am talking primarily not about disclosure at the time of an initial public offering but about what is provided periodically thereafter. Greater ongoing disclosure increases the effectiveness of the hostile takeover threat as a deterrent to such behavior. ${ }^{119}$ Disclosure also assists in the effective exercise of the shareholder franchise and in shareholder enforcement of fiduciary duties.

In determining the extent to which an issuer's entrepreneurs and managers will be able to capture the social benefits from its ongoing, post-IPO disclosure, we should start by observing that, like IPO disclosure, this information too has "public goods" aspects. It will aid both in the analysis of the prospects of issuers just going public with IPOs and in the disciplining of managers of other established public issuers through its assistance in the functioning of the takeover threat against them and of their share price based compensation incentives. These benefits will not be captured in the price of the individual issuer making the disclosure.

In contrast, an issuer's share price should reflect the social benefit arising from its disclosure's disciplining effect on its own managers. For private benefit to equal social benefit, however, the issuer's entrepreneurs or managers must fully capture this price improvement. This can only happen if the issuer can bind itself at the time of its IPO in an ironclad way to provide periodic disclosure at a given level for the life of the firm. The higher the promised level, the less the market would expect management decisionmaking to deviate from what is in the shareholder's best interests and the higher, net of the costs of this disclosure, the market price for the issuer's initial offering. The entrepreneurs would capture this price improvement through its resulting dollar-for-dollar increase in the size of the entrepreneurial surplus. ${ }^{120}$

Issuers operating under a transaction location system of statutory reach, however, are not able to provide this kind of commitment. Thus, the internalization of the benefits from the disciplinary effects of disclosure will not be complete because the market will not be confident that the issuer is totally bound to disclose at the

119. The reduction in managerial discretion is, as discussed above, a direct cost to managers even though it produces social gains through better resource allocation. The question here is the extent to which entrepreneurs and managers feel these social gains.

120. See Easterbrook \& Fischel, supra note 112, at 684. 
chosen level forever. ${ }^{121}$ The market knows that managers will be subsequently tempted to switch to a lower disclosure regime and, by switching where their shares trade, have the capability of doing so. This temptation arises because lower disclosure's reduction in the risk of takeover provides managers with room to make more decisions that satisfy their own objective functions at the expense of the interests of shareholders.

Admittedly, when the managers switch to a lower disclosure regime, the share price in the secondary market will decline because of the expected decline in managerial discipline. The managers, however, will often find the added takeover protection worth the share price decline. ${ }^{122}$ After all, their biggest concern with secondary market share price is often the takeover threat. The switch would also increase the issuer's cost of seeking additional capital through new share issues. Many established firms, however, never raise new capital in this fashion. Even for those that do, the cost of the lower share price will largely or wholly be borne by the existing public shareholders, not the managers.

\section{Conclusion}

The foregoing discussion clearly demonstrates that the transaction location approach creates a potential market failure. The approach permits U.S. issuers to exercise their preferences as to which disclosure regime they wish to be governed by. Over time they will be increasingly likely to exercise this preference and, to the extent that they do, they will choose regimes requiring them to disclose less than is socially optimal. In essence, the same reasons that call for the maintenance of a mandatory disclosure regime in the first place call for its statutory reach not to be determined on a transaction location basis. Assuming that U.S. officials attempt to act in the best interests of the United States in setting the level of required disclosure, ${ }^{123}$ this market failure means that the transaction

121. As a result, the case for signaling theory is inherently harder to make for periodic disclosure than IPO disclosure. Steven Ross, in his classic exposition of the theory, assumes that managers are a dollar better off for every dollar they increase the value of the firm. See Ross, supra note 10 , at 185 . Any story as to why this might be so in the case of periodic disclosure is much more complicated than in the case of an IPO, since, unlike the IPO, the entrepreneurs are not in essence selling a portion of the equity of the company previously belonging to them.

122. Managerial share ownership and stock options can ameliorate, but not eliminate, this probicm. Since such holdings constitute only a fraction of the issucr's outstanding shares - in most cases a small fraction - most of the reduction in share value from non-sharevalue maximizing decisions is externalized onto other persons.

123. This is a reasonable and conventional assumption in a study of the regulation of behavior with transnational effects. Even if U.S. officials have a bias toward requiring too 
location approach will, compared to the issuer nationality approach, lower U.S. welfare.

\section{B. The Transaction Location Approach Will Reduce the Volume of Share Transactions Effected in the United States}

\section{The Transaction Location Approach Will Discourage Issuers} With Privately Optimal Disclosure Levels Below What Is Required by the U.S. Regime from Entering the U.S. Market

The United States has the strictest disclosure regime in the world. ${ }^{124}$ A transaction location approach to the reach of this regime would, compared to the issuer nationality approach, reduce the volume of share transactions effected in the United States and thus lower the welfare of U.S. residents whose rents depend on this volume. The transaction location approach determines whether an issuer is subject to the U.S. disclosure regime based on whether or not the issuer's shares are offered, sold, or traded in the United States. Such a policy will discourage the entrepreneurs or managers of any issuer having a privately optimal disclosure level below U.S. requirements from establishing a U.S. market for its shares. The additional disclosure to meet U.S. requirements would involve more costs than benefits to them.

The typical foreign issuer is going to fall into that group. The starting point for seeing why is the fact, just established, that every issuer's privately optimal level of disclosure is lower than its socially optimal level. The next step is that the socially optimal level of disclosure of the typical foreign issuer is, in turn, lower than the socially optimal level of the typical U.S. issuer. This is because issuers from different countries, as discussed in more detail in Part V, show significant divergences in terms of both their internal decision structures and external environments. These divergences suggest differences in the extent to which disclosure will be effective in helping to align managerial and shareholder interests and to assure the best choice of proposed real investment projects. For a variety of reasons, disclosure is likely to be less effective in these regards

high a level of disclosure, as might be predicted by public choice theory, the transaction location approach will still lower U.S. welfare unless the bias is so strong that the required level is more suboptimally high than the level chosen by issuers is suboptimally low. These points are discussed in more detail infra in Part VII.

124. See stipra note 103 and infra note 149. 
with foreign issuers than with U.S. issuers, and so the socially optimal level of disclosure will be lower for the typical foreign issuer. ${ }^{125}$

The last step is that each country can appropriately be assumed to regulate in its own best interest. Thus the level of disclosure required by the U.S. regime will be an unbiased estimate of what is socially optimal for the typical U.S. issuer. We will examine this assumption in more detail in Part VII, where I argue that it is the reasonable and conventional one to make in a study of the regulation of behavior with transnational effects. Moreover, as we will see, to the extent that this assumption has been subject to criticism, it is that the U.S. required level is too high, not too low. Thus it is safe to say that the level of disclosure required by the U.S. regime is at or above the socially optimal level for the typical U.S. issuer.

In sum, a substantial majority of foreign issuers will be discouraged from making their shares available in the U.S. market under the transaction location approach. This is because the typical foreign issuer's privately optimal level of disclosure is well below what is required by the U.S. regime. Its private level is below its socially optimal level, which is below the socially optimal level for the typical U.S. firm, which, in turn, is at or below the U.S. requirements.

Under the transaction location approach, a significant number of U.S. issuers will be discouraged from having a U.S. market for their shares as well. The reason for that discouragement closely resembles the reason for foreign issuers. Every U.S. issuer will have a privately optimal disclosure level that is below its socially optimal one. The level required by the U.S. regime will be at or above the socially optimal level of the typical U.S. issuer. Thus the typical U.S. issuer would prefer to be bound by a disclosure regime requiring less than the level required by the U.S. regime. Under the transaction location approach, the impact of this preference on an issuer's choice of where to offer, sell, and promote the trading of its securities may not be great today, but, as discussed above, it will grow. ${ }^{126}$ This is because of a likely weakening over time of the other factors that influence this choice, as financial information becomes increasingly diffused globally and the cost and difficulty of effecting orders abroad goes down.

125. There is no reason to believe that the typical foreign issuer's costs would be comparably lower as weil, and so social marginal cost should equal social marginal benefit at a lower level of disclosure than with the typical U.S. issuer.

126. See supra section IV.A.1 and infra Part VI. 
2. Issuers Having Privately Optimal Disclosure Levels at or Above What Is Required by the U.S. Regime Will Not Be Attracted to the U.S. Market by the Transaction Location Approach

Most of the world's issuers of any significance would want to have their shares offered and traded in the United States absent such transactions triggering imposition of the U.S. regime. This is because United States markets provide better access to U.S. residents, the biggest single pool of investors in the world. U.S. exchanges also provide superior execution to that of their foreign counterparts. ${ }^{127}$ Consequently, issuers with privately optimal disclosure levels at or above the level required by the U.S. regime would have their shares offered and traded in the U.S. market whether or not that resulted in imposition of the U.S. regime. Thus the transaction location approach does nothing to attract such issuers, because they will be in the U.S. market regardless.

The approach fails to attract such issuers for another reason as well. At least as far as periodic Exchange Act disclosure is concerned, nothing appears to prevent such issuers from registering their shares, and hence gaining the advantages of binding themselves to the world's strictest regime, whether or not their shares trade in the United States. ${ }^{128}$

\section{Conclusion}

The transaction location approach to statutory reach reduces the volume of share transactions effected in the United States and thus the welfare of U.S. residents whose rents depend on such volume (those associated with the securities industry and the exchanges). The approach discourages all issuers whose entrepreneurs or managers find that their costs of compliance with the U.S. regime are greater than their benefits, a group that probably includes a substantial majority of all the world's issuers. And it

127. The total costs of executing a trade (including the effect of the order itself on the price) is significantly lower on the New York Stock Exchange and NASDAQ than on foreign markets. See Amar Bhide, Efficient Markets, Deficient Governance, Harv. Bus. Rev., Nov.Dec. 1994, at 129; Joel Chernoff, London Trading Costs Rise, Pensions \& Investments, July 25, 1994, at 20;

128. Professors Choi and Guzman argue that an issuer having its shares trade in the United States would, under the transaction location approach, economically communicate to the market that the issuer is disclosing at the U.S. level. See Choi \& Guzman, Dangerous Extraterritoriality, supra note 9, at 229-30. This is true. However, the mere fact of registration alone economically communicates the same thing and, under the efficient market hypothesis, should be fully reflected in share price even if not all market participants are aware of it. 
does nothing to attract issuers for whom the benefits from compliance do equal or exceed the costs. This second group of issuers is likely to have their shares trade in the United States whatever approach to statutory reach the United States adopts. In any event, members of this second group can register their shares under the Exchange Act and obtain the benefits of compliance without having their shares trade in the United States.

\section{The Superiority of the Issuer Nationality Approach over Any Achievable International Agreement}

\section{A. National Differences in Issuer Decision Structures}

There are likely to be important differences among issuers worldwide in terms of the level of disclosure that will maximize the returns (net the costs of this disclosure) that their capital utilizing productive activities generate. These differences in their socially optimal disclosure levels are significantly related to the nationalities of the issuers involved.

The operating and project choice decisions of an issuer that is publicly held or is seeking public financing are the product of both the internal decision making structure of the issuer and the external environment that provides the inputs that make this structure function - most important for our concerns, shareholder votes and new capital. The internal decision making structure arises out of a combination of the law of the jurisdiction of incorporation and the issuer country's traditional business customs and practices. ${ }^{129}$ The

129. For a classic survey of the differences among countries in terms of these internal decisionmaking structures, see Alfred F. Conard, Corporatjons in Perspective (1976). See also Melvin Eisenberg, The Structure of the Corporation: A Legal Analysis (1976). The statutory differences among countries are obvious, but differences in traditional business customs and practices are also important in determining these internal decisionmaking structures.

The influence of traditional business customs and practices is reflected in part in differences among countries in their corporations' typical basic constitutive documents (their articles of incorporation or equivalent). Large, publicly held corporations of a given country are likely to have constitutive documents that have more in common with each other than with those of corporations of other countries. This is in part because the "network externalities" associated with having similar constitutive documents are stronger domestically than transnationally. There is a degree of path dependency in the development of typical terms for any given country, and the factors that determine the starting point have chance qualities that will vary from one country to another. See Michael Klausner, Corporations, Corporate Law, and Neiworks of Contracts, 81 VA. L. REV. 757 (1995).

The influence of traditional business customs and practices are reflected as well in the behavior that occurs within the legal structure set up by statute and the basic constitutive documents. Thus, for example, the board of directors of the typical U.S. public corporation is given the power to manage the corporation and direct its policy, but traditionally the board has done neither. This is in part because of the limited amount of time that outside directors have expected to devote to the job, the limited amount of information they have expected to receive and review, and their reluctance to meet separately from full-time management. See 
external environment is determined by a number of factors including the degree of concentration of share ownership, the nature of the holders of any such concentrated blocks, the rules and practices under which these holders use their voting power singly and in cooperation with others, the extent to which the legal system and suppliers of finance facilitate or hinder hostile takeovers, and the relative availability of financing in different forms (equity versus debt) and from different sources (private versus public markets).

Comparative corporate governance has become an important subject for legal and financial scholars in recent years and the resulting studies show significant contrasts among countries in both internal decision structures and external environments. ${ }^{130}$ These contrasts suggest differences in the extent to which disclosure will be effective in helping to align managerial and shareholder interests and in assuring the best choice of real investment projects. That, in turn, suggests that the optimal level of disclosure, where the social marginal benefits just equal the social marginal costs, may be higher in one country than in another.

By way of illustration, a set of rough contrasts can be made between, on the one hand, the United States and Canada (and, to a lesser extent, the United Kingdom), which have relatively strict disclosure regimes, and, on the other, Germany and Japan, which have more lax ones. ${ }^{131}$ These contrasts suggest significant differences in the value of disclosure. Voting power in U.S. issuers is less concentrated, and institutional investors in U.S. issuers are less inclined, separately or together, to exercise their voting power to influence

John C. BAKer, Directors ANd THEIR Functions 12-18 (1945); EISENBERG, supra, at 13948; Robert A. Gordon, Business Leadership in the Large Corporation 79-146 (2d ed. 1961); Myles Mace, Directors: Myth and Realtiy (1971): Bayless Manning. The Business Judgment Rule and The Director's Duty of Attention: Time for Reality, 39 Bus. Law. 1477 (1984). Starting in the early 1990s, however, some boards have begun to take a more aggressive stance, as indicated by the firing of some prominent chief executives. See, e.g., Brett D. Fromson, American Express: Anatomy of a Coup, WAsh. Post, Feb. 11, 1993, at A1; Doron P. Levin, Stempel Quits Job As Top G.M. Officer in Rift with Board, N.Y. TIMES, Oct. 27, 1992, at A1; Steve Lohr. Big Business in Turmoil: Upheavals at I.B.M., Sears and Elsewhere Underline Fundamental Shifts in Economy, N.Y. TIMEs, Jan. 28, 1993, at A1; Steve Lohr, I.B.M. to Replace Its Top Executive, N.Y. TImEs, Jan. 27, 1993, at A1. While increased pressure by institutional investors is an important factor in this shift, it appears to reflect as well an underlying change in business culture as directors reconceptualize their role and change their expectations concerning the time they devote to the job, the information they receive, and their overall separateness from their companies' full-time managers.

130. See, e.g., Mark J. Roe, Strong Managers, Weak Owners: The. Political Roots of American Corporate Finance (1994); Bernard S. Black \& John C. Coffee, Jr., Hail Britannia? Institutional Investor Behavior Under Limited Regulation. 92 MiCH. L. REV. 1997 (1994).

131. See infra note 149. 
corporate decisions. ${ }^{132}$ Debt/equity ratios are lower ${ }^{133}$ and there is more use of publicly offered equity as a source of finance, ${ }^{134}$ particularly by relatively new companies financing major projects. Hostile tender offers are more frequent, as are solicitations of public shareholders in proxy fights. ${ }^{135}$ In contrast, in Germany and Japan,

132. See, e.g., RoE, supra note 130 , at 22, 169-70.

133. See, e.g., F.X. Browne, Corporate finance: stylized facts and tentative explanations, 26 APPLiEd ECON. 485, 488 (1994) ("[Non-financial f]irms in securities-based financial systems (the United States, the United Kingdom and Canada ... ) have quite low debt/equity ratios compared to those in the bank-based systems of Japan, Germany and France.").

134. See, e.g., Browne, supra note 133, at 494 (stating that internal funding is significantly greater in the United States, the United Kingdom, and Canada than in Japan and continental Europe).

135. With respect to Germany, for example, see RoE, supra note 130, at 172. According to Roe, a concentration of voting power in the hands of banks makes an American style proxy fight nearly impossible. German banks maintain control over stock in three ways: (1) they own the stock themselves; (2) they control mutual funds, which own stock; and, most importantly, (3) they possess authority to vote stock that the bank's brokerage customers own, but deposit with the bank. See also Ronald J. Gilson. The Political Ecology of Takeovers: Thoughts on Harmonizing the European Corporate Governance Environment. 61 Fordham L. Rev. 161, 181 (1992); Douglas G. Smith. A Comparative Analysis of the Proxy Machinery in Germany, Japan, and the United States: Implications for the Political Theory of American Corporate Finance, 58 U. PrtT. L. Rev. 145, 181-82 (1996).

The difficulty of conducting a hostile takeover offer in Germany is illustrated by Pirelli's well publicized 1991 attempt to take over the German tire company Continental, the only attempt to take over a major German firm in recent memory. Continental recruited Germany's largest commercial bank to mount its takeover defense and persuaded other German companies, such as Daimler-Benz, to purchase large quantities of its stock. When shareholders repealed a five percent cap on individual shareholder voting, Continental successfully challenged the action in the German courts. Pirelli reportedly spent $\$ 290$ million in connection with the failed merger. See Ferdinand Protzman, Costly German Lesson: Pirelli's Failed Takeover, N.Y. TIMEs, Dec. 3, 1991, at D2; Mark R. Wingerson \& Christopher H. Dorn, Institutional Investors in the U.S. and the Repeal of Poison Pills: A Practitioner's Perspective, 1992 Colum. Bus. L. Rev. 223, 250; Tire Maker Calls Off Merger Plan, N.Y. Times, Dec. 2 1991, at D5.

The absence of hostile takeovers in Japan has been noted by many commentators. A number of writers point out that because of a complex network of inter-corporate and bank equity holdings, it is exceedingly difficult for outside companies to acquire controlling blocks of shares in a target company. See, e.g., J. Robert Brown, Jr., In Defense of Management Buyouts, 65 Tul. L. REv. 57, 83 n.74 (1990); John C. Coffee, Jr., Liquidity Versus Control: The Institutional Investor as Corporate Monitor, 91 Colum. L. Rev. 1277, 1299-300 (1991); Ronald J. Gilson, Corporate Governance and Economic Efficiency: When Do Institutions Matter?, 74 WAsh. U. L.Q. 327, 328 (1996); Jonathan R. Macey \& Geoffrey P. Miller, Corporate Governance and Commercial Banking: A Comparative Examination of Germany, Japan and the United States, 48 STAN. L. Rev. 73, 81, 100 (1995); Curtis J. Milhaupt, Managing the Market: The Ministry of Finance and Securities Regulation in Japan, 30 STAN. J. INTL. L. 423, 437-38 (1994).

It is a matter of debate whether these hostile takeover defeating stockholding arrangements represent a mechanism for self-serving management entrenchment, as some of these commentators imply, or an efficient response to the complex problem of corporate governance. Mark Ramseyer has argued that the lack of hostile takeovers in Japan might illustrate some of the inefficiencies inherent in the hostile takeover mechanism. Ramseyer argues that hostile takeovers, by allowing shareholders to renege on implicit bargains struck with management, allow shareholders to capture any organizational rent the firm earns. Moreover, Ramseyer suggests that in reducing the levels of future managerial compensation, hostile takeovers reduce the incentives for managers to make firm-specific investments. See J. Mark Ramseyer, Takeovers in Japan: Opportunism, Ideology and Corporate Control, 35 UCLA L. 
institutional investors play a larger role both in monitoring managerial behavior ${ }^{136}$ and in supplying finance, mostly debt. ${ }^{137}$

\section{B. National Practice Reflects Resulting Differences in Optimal Disclosure Levels}

The picture painted here suggests that the socially optimal level of disclosure for U.S. issuers would be higher than for German and Japanese ones. U.S. institutional investors monitor less carefully the way managers of U.S. issuers make both operating and project choice decisions. They collect, analyze, and act on less information (both public and non-public) concerning these matters. Thus, more of the work of aligning managerial and shareholder interests with respect to these decisions falls to the hostile takeover threat and share price based managerial compensation, both of which are assisted by greater public disclosure. Greater disclosure and its enhancement of share price accuracy is also of more assistance to good project choice in the United States because of the greater reliance by U.S. "start-up" companies on the public equity markets. ${ }^{138}$ The choice of required disclosure levels by these different countries conforms with what this rough illustration calls for. The United States and Canada require the most, Germany and Japan the least, with the United Kingdom somewhere in between. ${ }^{139}$

\section{Implications for the Likelihood of an International Regime}

The preceding discussion suggests that there are different optimal levels of disclosure for issuers of different countries and that countries have recognized and acted on these differences. This makes unlikely the adoption of an international regime imposing a

REV. 1 (1987); see also Corrine A. Franzen, Increasing the Competitiveness of U.S. Corporations: Is Bank Monitoring the Answer?, 2 Minn. J. Global. Trade 271, 292 (1993) (suggesting that Japan may not need hostile takeovers since greater bank involvement in corporate management is more efficient than the takeover market discipline system of the United States).

136. See RoE, supra note 130 , at 169 (noting that senior managers in Germany and Japan share power with active intermediaries who control large blocks of a company's stock).

137. Japanese firms borrow $\$ 5.33$ from banks for every dollar they raise in the capital markets, German firms $\$ 4.20$, and American firms $\$ 0.85$. See Macey \& Miller, supra note 135 , at 85,89 .

138. Ronald Gilson and Bernard Black show that the prospect of a vibrant market for initial public offerings in the United States for issuers that have shown a certain degree of success greatly facilitates the earlier provision of venture capital to get them off the ground in the first place. This, they argue, explains why there is so much more venture capital available in the United States. See Ronald Gilson \& Bernard Black, Venture Capial and the Structure of Capital Markets: Banks versus Stock Markets, 47 J. Fin. Econ. 243 (1998).

139. See supra note 103; infra note 149. 
uniform level of disclosure for all issuers around the world: whatever level might be proposed, it will, for most countries, be inferior - either too high or too low - compared to the level called for by their current regimes. Most countries would therefore be disinclined to agree to adoption of the regime. For some of them, there would be some attractions as well to having a uniform international regime, but, as discussed below, these attractions would, for now, in most cases appear insufficient to overcome their likely opposition.

\section{Administrative Convenience}

The primary attraction of a uniform international regime cited by commentators is administrative convenience: issuers would be saved from having to comply with multiple national regimes. ${ }^{140}$ This problem is also avoided, however, by a nationally based system of disclosure regulation as long as the countries use the issuer nationality approach to statutory reach advocated here. In fact, a nationally based system using the issuer nationality approach would be significantly more convenient administratively than an international regime since dealings between the entrepreneurs or managers of the issuers and the officials regulating them would be between persons who share a common culture and understanding of business practices. ${ }^{141}$

\section{Common Language}

A second possible attraction of an international regime would be the creation of a common language and format used by all issuers around the world in their mandated disclosure. Having a group of issuers use the same language and format facilitates comparisons and makes communicating at any given level of precision more economical for both the sender and receiver. Indeed, this is one ration-

140. See, e.g., Release No. 6568, supra note 21 (suggesting agreement among several countries on a single prospectus format and common disclosure standards as one possible approach to facilitating multinational offerings); see also John M. Fontecchio, The General Agreement on Trade in Services: Is It the Answer to Creating a Harmonized Global Securities System?, 20 N.C. J. INTL. LAW \& COM. REG. 115, 123 (1994) (suggesting that GATS be considered as a means to pull the governments of the world toward a harmonized global securities market); Manning Gilbert Warren III, Global Harmonization of Securities Laws: The Achievements of the European Communities, 31 HARv. INTL. L.J. 185, 187 (1990).

141. Professors Fanto and Karmel conducted a survey of foreign issuers that had registered their shares with the SEC. Their results provide an example of this kind of problem. Some of the surveyed issuers complained that the SEC staff was unfamiliar with the business, accounting and legal practices in their countries, thereby generating more lawyer involvement and expense. See FanTO \& KarmeL, supra note 21, at 32-35. 
ale for mandatory disclosure in the first place. ${ }^{142}$ Without any regulation, each of the tens of thousands of public issuers around the world would be speaking its own language. Already today with national regulation, however, this babel is being largely reduced to "languages" associated respectively with the regimes of the relatively small number of major capitalist countries. A major portion of the capitalized value of the world's publicly traded equities is issued by issuers subject to these regimes. ${ }^{143}$ There is evidence that a sufficient number of speculators are "multilingual" that share price accuracy for these issuers will not be significantly enhanced by further movement to the single language of an international disclosure regime. ${ }^{144}$

\section{Transborder Externalities}

The third possible attraction to a global regime arises from positive transborder externalities in a nationally based system produced by the disclosures of each country's issuers. These externalities, which would be eliminated under a global regime, bias each coun-

142. See Easterbrook \& Fischel, supra note 112, at 685-87. They argue that while standardized information fosters comparison across investments, no firm will offer such information on its own because the benefits of comparison spill over to the firm's competitors. They suggest that mandatory disclosure rules promulgated by the government are one form of collective action available to solve this problem.

143. At year-end 1994, seven countries - the United States, Canada, the United Kingdom. France, Italy, Japan, and Germany-together accounted for $75 \%$ of the world's total market capitalization of nearly $\$ 15.2$ trillion. See International Finance Corporation, EMerging Stock Markets FactBook 1995, at 15 (1995).

\begin{tabular}{lr}
\multicolumn{2}{c}{1994 Year-End Capitalization } \\
\hline Market & US\$ millions \\
\hline Canada & $\$ 315,009$ \\
France & 451,263 \\
Germany & 470,519 \\
Italy & 180,135 \\
Japan & $3,719,914$ \\
U.K. & $1,210,245$ \\
U.S. & $5,081,810$ \\
\hline G7 Total & $\$ 11,428,895$ \\
World Total & $\$ \mathbf{1 5 , 1 8 5 , 6 0 7}$ \\
\hline
\end{tabular}

See id. (based on data presented in the Developed Markets capitalization chart).

144. One way to test this proposition is to compare, for foreign issuers listed on a U.S. exchange, the response of their share prices when they originally announce their earnings prepared on the basis of home country conventions, with the response of their share prices when they subsequently announce these earnings reconciled with U.S. GAAP. Gary Meek performed such a test and found that the price response to the first announcement suggests it has considerable information value, while the price response to the second announcement suggests that it does not add anything significant. See Gary K. Meek, L.S. Securities Market Responses to Alternate Earnings Disclosures of Non-U.S. Multinational Corporations, THE ACCT. Rev.. Apr. 1983, at 394. 
try's decision concerning its level of required disclosure toward a level lower than what is optimal from a global welfare perspective. While real, this attraction is probably not sufficient to overcome the obstacles to a uniform regime.

a. The transborder externality bias. To understand the bias induced by transborder externalities, recall from Part IV that for each individual issuer, disclosure involves two different kinds of costs, "interfirm" costs and "operational costs." 145 Interfirm costs arise from the fact that the information provided can put the issuer at a disadvantage relative to its competitors, major suppliers, and major customers. They are not, in general, social costs because the disadvantage to the issuer is counterbalanced by the advantages conferred on the other firms. For the typical issuer, as long as it and its competitors, major suppliers, and customers are all subject to the same regime, the existence of a mandatory disclosure regime involves a wash in terms of these interfirm disadvantages and advantages. Where this is the case for all issuers subject to regulation, national officials, in determining what level of disclosure will maximize national welfare, can ignore interfirm costs and focus on the tradeoff between greater disclosure's efficiency gains from better management and project choice, on the one hand, and its higher operational costs, on the other.

In a world with international trade and multinational corporate operations, however, some of an issuer's competitors and major suppliers and customers may not share the issuer's nationality and so will not be slibject to the same disclosure regime as the issuer is. This problem biases a national government downward when it sets its required disclosure level because it knows that its issuers will suffer all of the interfirm costs, but receive only part of the interfirm advantages, from the disclosures it mandates. Thus, in calculating the optimal level of disclosure in terms of the welfare of its residents, it will consider not only its operational costs but also the cross-border portion of interfirm costs.

The cross-border interfirm costs that national governments consider in their calculations are not, however, social costs from a global welfare point of view. Each issuer's interfirm disadvantages from disclosing information will be fully counterbalanced by advantages to its competitors, major suppliers, and major customers, once foreign as well as domestic firms are included in the calculation.

145. See supra section IV.A.2.a. 
Thus global welfare would be enhanced if the officials determining required disclosure levels did not consider cross-border interfirm costs.

b. The improbability of a single, uniform regime solution. Creation of a single, uniform international regime would eliminate consideration of all interfirm costs. Each of the world's issuers would then be subject to the same regime as all of its competitors, major suppliers, and major customers. ${ }^{146}$ Thus the same officials would determine the required disclosure level for all of them, and the decision setting their level of disclosure would be subject to no externalities. ${ }^{147}$

There is good reason to believe, however, that this third attraction of a uniform regime, while the most real, will be insufficient to gain the agreement of all parties. To start, the gain from eliminating externalities is probably less than the problem with a uniform international regime that led to our skepticism about its adoptability in the first place. An indication that these externalities are not a matter of intense concern is the fact that large U.S. corporations

146. This problem could theoretically be solved without scrapping the world's current nationally based system of regulation. An international agreement could provide that each country would receive a subsidy for the interfirm advantages abroad arising from its chosen level of mandatory disclosure. This would eliminate the bias toward underdisclosure, while preserving the capacity to tailor mandated disclosure levels to reflect national differences among the world's issuers. Like any global welfare enhancing proposal, such an agreement is potentially attractive to all parties because, at least in theory, it is possible to split up the consequent wealth gain in a way that leaves every country better off. Such an agreement seems very unlikely, however. Just as a threshold matter, it is hard to imagine a consensus forming on a way of measuring extraterritorial interfirm advantages.

147. The elimination of the externalities results from the fact that the regime is international. not that it is uniform. My colleague James Krier has made the point in the context of federal versus state environmental regulation that the United States could have federal regulation but with non-uniform standards. This would eliminate externalities while permitting rules to be tailored to the particular regulatory costs and benefits of each area. See James E. Krier, The Irrational National Air Quality Standards: Macro- and Micro-Mistakes, 22 UCLA L. REv. 323, 328-30 (1974); James E. Krier, On the Topology of Uniform Environmental Standards in a Federal System - and Why it Matters, 54 MD. L. ReV. 1226, 1236-37 (1995).

In theory, the same could be said about international versus national regulation of disclosure, but some critical differences render the idea inapplicable here. Compared to federal officials assessing the environmental situation in the states, international officials are likely to be at a much greater distance - physically, culturally, linguistically, and experientially from the particular features in each country that lead to differences in regulatory costs and benefits of disclosure regulation. Also, these distances matter more since the national differences in the disclosure area are entirely institutional whereas in the state, differences in the environmental area are, to some extent, physical and more describable in generally accepted technical terms. Most importantly, there is no overarching world governmental organization that would enhance the political accountability of international disclosure regulation officials in a way comparable to the role of the federal government in the lives of federal environmental regulators. This kind of accountability would be essential in a system where the officials were making decisions about differential treatment based on different national needs and transborder effects. 
have voiced almost no opposition to proposals by the New York Stock Exchange to permit the listing of major foreign issuers without reconciling their financials to U.S. generally accepted accounting practices. ${ }^{148}$

Assume for argument, however, that the externality problem, which a uniform regime eliminates, is in fact more serious than the untailored disclosure level problem that a uniform regime creates, so that a uniform regime would lead to a global wealth gain. Even then, adoption is unlikely. Many countries - the ones whose current required disclosure levels are lower than the uniform level of the international regime - would still in fact lose, not gain, from elimination of the externality. Issuers from these countries would be hurt two ways. First, their increased disclosure would increase the harm they suffer as a result of competitors, major customers, and major suppliers abroad finding out additional things about them. Second, they would find out less about their competitors, major suppliers, and major customers that are from countries whose current required disclosure levels are higher than the uniform one. Admittedly, with a global wealth gain, the winning countries' gains would more than match the losing countries' losses. And so, in theory, transfers could be arranged from the winners to the losers that would leave every country better off. Effecting such transfers would be difficult as a practical matter, however. Unlike a trade pact, for example, adoption of a uniform regime would not involve a complex of terms each of which has its own distinct pattern of impacts on the necessary parties, so that every party can be given enough points of particular importance to it to find the agreement as a whole worthwhile.

148. The Securities and Exchange Commission (SEC) and the International Accounting Standards Committee (IASC) are negotiating a proposal that would allow foreign issuers to list their shares on U.S. exchanges by following international rather than U.S. accounting standards. The New York Stock Exchange has been instrumental in moving the proposal forward. It has found a sympathetic ear with Congress, which provided in the National Securities Market Improvement Act of 1996 that the SEC prepare within one year a report "on progress in the development of international accounting standards and the outlook for successful completion of a set of international standards that would be acceptable to the Commission for offerings and listings by foreign corporations in United States markets." Pub. L. No. $104-290, \$ 509,110$ stat. 3416,3449 (1996). The SEC staff, however. has stated that the Commission will not accept international accounting standards which depart significantly from the philosophy, coverage, and specificity of U.S. standards. See Richard Leftwich, $O b$ stacles to Global Accounting Deal, Fin. Times, May 19, 1997 (Mastering Finance Supplement). at 2. A search of the popular press reveals no opposition from large U.S. corporations to the Exchange-backed plan despite the fact that foreign issuers would be required to disclose less than U.S. corporations must. The New York Stock Exchange does note objection by U.S. accountants and foreign issuers already using U.S. generally accepted accounting principles. See Jim Kelly, World Accounting Wins More Converts, Fin. Times, June 9, 1997. at 4 . 
Vi. How Globalization Increases Political Pressure to Lower U.S. Disclosure Standards Under the Investor Residency and Location of Trade Approaches bUt Not Under the IsSUer Nationality APPROACH

We have just seen that the issuer nationality approach to selecting issuers covered by the U.S. regime will result in a higher level of U.S. economic welfare than will the investor residency or location of trade approaches, at least under the simplifying assumption in Parts III-V that the choice of approach will not affect the future content of that regime. In fact, though, the choice of approach will affect the regime's future content. Thus, the welfare implications of the choice of approach are more complex than they have been portrayed so far. Consideration of this more complex picture, however, ultimately reinforces the conclusion that issuer nationality is the superior approach to statutory reach.

The United States has the strictest mandatory disclosure regime of all the major capitalist states. ${ }^{149}$ In these last two parts of the

149. The United Kingdom is a critical country for comparison with the United States. The United Kingdom is the home of the International Stock Exchange (formerly the London Stock Exchange), which, along with the New York Stock Exchange and the Tokyo Stock Exchange, is one of the world's three major stock exchanges. The United Kingdom is considered by the SEC to have disclosure requirements that are closer to those of the United States than those of other countries (except Canada). See Release No. 6568, supra note 21. Nevertheless, a detailed comparison between the disclosure requirements of the United States and the United Kingdom for companies that issue equity securities reveals that the U.S. requires significantly more information. Differences in requirements include the amount of detail that must be provided describing the nature of the issuer's business, the need to provide data concerning the results of the different lines of business in which the issuer participates, the need to discuss trends that management identifies as affecting the issuer's future liquidity, capital needs or operating results, and the need to provide information about management compensation and share ownership. See SEC Proposals to Facilitate Multinational Securities Offerings: Disclosure Requirements in the United States and the United Kingdom, 19 N.Y.U. J. InTl. L. \& Pol. 457, 459-68 (1987); see also George Benston, Corporate Financial. Disclosure in the UK and the USA 20-21, 37 (1976); Report of the Staff of the U.S. Securities and Exchange Commission to the Senate Cammittee on Banking Housing and Urban Affairs and the House Committee on Energy and Commerce on the Internationalization of the Securities Market III-91 (1987) [hereinafter SEC Internationalization Report]. European countries in general put much less emphasis on full disclosure. See Peter Widmer, The U.S. Securities Laws - Banking Law of the World? (A Reply to Messrs. Loomis and Grant), $1 \mathrm{~J}$. Comp. Corp. L. \& SEC. Reg. 39 (1978). Japan, the home of the Tokyo Stock Exchange, has a securities statute that closely parallels the Securities Act and the Exchange Act of the United States. However, the staff responsible for promulgating and implementing regulations and enforcement is very small compared to that of the SEC, and many provisions of the statute are treated as inoperative. The emphasis is on de facto screening of issuers by regulatory authorities rather than full disclosure. See Kunio Hamada \& Keiji Matsumoto, Securities Transaction Law in General, in 5 DoING Business IN JAPAN VIII 1-1, \$\$ 1.02[1] and 1.02[4] (Zenturo Kitagawa ed., 1987); SEC Internationalization Report, supra, at III-127.

The United States, in addition to having a set of regulations and an administrative apparatus that solicit more information from issuers than those of other countries, has a liability system as well that prods more information out of issuers. Under Section 11 of the Securities Act, the issuer is absolutely liable for materially false or misleading statements in the registration statement. The underwriter is liable as well unless it sustains the burden of proof that 
paper, I show that in the face of increasing globalization, a relaxation of this regime is likely if the United States stays on its current path of determining statutory reach in significant part on the basis of residency of the buyers and the place where the transactions occur. This relaxation will be the consequence of increasing political pressure by persons seeking to maximize the number of transactions effected in the United States, most significantly persons associated with the U.S. securities industry and the U.S. exchanges. This relaxation will occur even if, as seems likely, it diminishes U.S. welfare. A switch to a pure issuer nationality approach would avoid these pressures and hence this welfare diminishing relaxation.

This Part analyzes how, without the switch to the issuer nationality approach, the level of U.S. disclosure requirements is inversely related to the volume of transactions effected in the U.S. (at least in the absence of reaction by other countries) and how growing globalization will increase the sensitivity of this inverse relationship. Growing globalization will therefore increase political pressure to relax the requirements since, with this increased sensitivity, a given decrease in the level of required disclosure will lead to a larger improvement in U.S. volume.

Securities globalization consists of two trends. First, investors everywhere will be at a diminishing information disadvantage concerning issuers from other countries. Second, effecting share transactions abroad will become increasingly inexpensive and easy. As a result of these trends, the market for securities of issuers of any significance will become an increasingly global one in the future. If the United States switches to a pure issuer nationality approach, as recommended here, this trend toward globalization will not result in any pressures to reduce the rigor of the U.S. mandatory disclosure regime. If, however, the U.S. adheres to its current approach, with its emphasis on investor residency and transaction location, these same trends will increasingly have just that result.

Why this disparity in result? When issuers choose whether or not to have their shares offered, sold, or traded in the United States, they may be sensitive, to one extent or another, to the level of disclosure required by the U.S. regime. The greater this sensitivity, the greater the number of issuers that, while unwilling to have their shares offered or traded in the United States under current

after conducting a reasonable investigation ("due diligence"), it had reason to believe and did believe that the registration statement contained no materially false or misleading statements. The liability system in the United Kingdom, for example, is not as far reaching. See SEC Internationalization Report, supra, at III-116. 
U.S. disclosure standards, would be willing to do so if these standards were relaxed by some given amount. Thus greater issuer sensitivity leads to a greater desire to have the U.S. standards relaxed by interests whose well being depends on the volume of transactions effected in the United States. Globalization's effect on this sensitivity will depend on the approach the United States adopts to statutory reach.

\section{A. The Issuer Nationality Approach}

Under a pure issuer nationality approach, an issuer's choice of whether or not to have its shares offered or traded in the United States would have no impact on whether the U.S. regime would apply to it. Thus, with regard to this choice, issuers are completely insensitive to the required disclosure level of the U.S. regime. The regime would either apply or not, depending on factors entirely independent of this choice. Since the U.S. regime's required level of disclosure is irrelevant to issuers' choices as to where to have their shares offered and traded, it has no effect on the volume of transactions effected in the United States. Globalization in no way changes this and so, as it intensifies, persons whose welfare depends on this volume will not put increased pressure on U.S. officials to lower U.S. disclosure requirements.

The desensitizing effect of a switch to the issuer nationality approach will also be welfare enhancing in terms of issuer choices as to where to have their shares offered and traded. The choice of each issuer, rather than being guided by an effort to come under the regulatory regime it prefers, will instead depend solely on the economic fundamentals of the situation: the efficiency with which different markets effect trades, the country or countries of residence of their most likely investors, and the extent to which such investors find markets in their own country or countries the cheapest and most convenient places to transact.

\section{B. The Investor Residency and Transaction Location Approaches}

\section{General Considerations}

When, as now, factors relating to the residence of the buyers and where the transactions occur are taken into account in determining whether to apply the U.S. regime, the issuer will be sensitive to the level of U.S. disclosure standards. The issuer can often avoid being subject to the U.S. regime by not offering shares in the United States and by not promoting their secondary trading there. 
The efficacy of this strategy of avoidance arises in part because the U.S. explicitly uses the place where transactions in an issuers' shares are effected as a factor in determining whether or not to apply its regime. ${ }^{150}$ The strategy also helps an issuer avoid the U.S. regime because, without offerings or secondary trading in the United States, two other factors used by the United States in determining whether or not to apply its regime - the percentage of the issuer's shares held by U.S. residents and the absolute number of such U.S. holders ${ }^{151}$ - are likely to be lower as well.

As discussed in Part IV, the world's issuers fall into two groups: a minority whose privately optimal level of disclosure is at or above the level required by the U.S. regime, and a substantial majority whose privately optimal level is below the U.S. requirements. ${ }^{152}$ Whichever group they are in, most of the world's issuers of any significance would want to have their shares offered and traded in the United States absent the fact that such offering or trading would trigger imposition of the U.S. regime. ${ }^{153}$ United States markets provide better access to the huge investor pool of U.S. residents and superior execution. ${ }^{154}$ Both lead to a higher share price. ${ }^{155}$ Under the current approach, however, the U.S. regime, with the highest level of required disclosure in the world, is in general imposed on issuers whose shares are sold or traded in the United States. ${ }^{156}$ The first group of issuers - those that prefer a regime at

150. Location is an explicit factor not only when we try to implement the goal of market protection (where location represents the whole concern), see supra notes 25-35 and accompanying text, but also where we try to implement the goal of investor protection. See supra notes 21-22 and accompanying text. The rationale here is presumably that the effecting of a significant number of transactions in an issuer's shares in the United States is an indicator that there are a significant number of U.S. resident investors in need of "protection."

151. See supra notes $36-49$ and accompanying text.

152. See infra section IV.B.2.

153. See Romano, supra note 15 , at 2419.

154. See supra note 127 and accompanying text.

155. See Choi \& Guzman, Dangerous Extraterritoriality, supra note 9, at 225. A recent paper by two economists at the New York Stock Exchange (NYSE) suggest that a foreign issuer that lists on the NYSE will enjoy an $8 \%$ increase in share price. See Katherine SMITH \& George Sofianos, The Impact of an NYSE Listing on the Global Trading of Non-U.S. STOCks 9 (NYSE Working Paper 97-02, 1997).

156. As discussed in Part I, compliance with the Exchange Act's periodic disclosure requirements is necessary for any foreign issuer's shares to trade on a U.S. stock exchange. Through a grandfathering provision, a number of foreign issuers that were trading on NASDAQ prior to October 6, 1983 have been permitted to continue to do so by meeting a substitute. minimal disclosure requirement. Any foreign issuer wishing to commence NASDAQ trading now, however, must undertake full compliance. Full compliance is not necessary for a foreign issuer's shares to be traded in the United States in a forum other than an organized U.S. exchange or NASDAQ. Such an issuer can commence having its shares traded among U.S. brokers on the basis of the "pink sheets" simply by meeting the same substitute minimal requirements imposed on the grandfathered NASDAQ issuers. The 
least as strict as the existing U.S. regime - will be neither attracted nor discouraged by the current approach because they would wish to be in the U.S. market in any event. The second, majority group of issuers - those that prefer a regime less strict than the existing U.S. regime - will be discouraged by it. The focus of the rest of Part VI is on this second group since only with them is there, under the current U.S. approach to statutory reach, a relationship between the rigor of the U.S. regime and the volume of transactions effected in the United States. Their entrepreneurs or managers would find compliance a burden. ${ }^{157}$

In deciding whether to have their shares offered or traded in the United States, the entrepreneurs or managers of this second group must compare this burden with the advantages of better access to U.S. investors and better execution. Those that find the advantages less than the burden of compliance will avoid the U.S. market.

These issuers' avoidance of the United States represents forgone rents for U.S. persons whose welfare depends on the volume of transactions effected in the United States. In order to minimize the number of issuers avoiding the U.S. market, these persons can be expected to exert ongoing pressure on U.S. officials for lower U.S. disclosure requirements. ${ }^{158}$ Current disclosure standards are the product of a combination of this pressure and the purely domestic forces that, but for the existence of foreign issuers and foreign markets, would by themselves set U.S. disclosure requirements.

Despite the burden of compliance, avoiding the U.S. market traditionally has not made sense for U.S. issuers since the United

spreads associated with this kind of trading are considerably larger, however, and thus investors purchasing these shares will experience a lower expected return and less liquidity. See, e.g., Iain Jenkins, 'Pink Sheets' Mix Risk With Rewards, Intl. Herald Trib., Nov. 19-20, 1994, at 19 (noting that the spread in the OTC market for ADRs can be as much as $10 \%$ ).

157. By definition, the entrepreneurs or managers of an issuer with a privately optimal level of disclosure below the U.S. regime's required level would find the U.S. regime a burden. See supra section IV.A.2. The burden that U.S. disclosure requirements impose on many foreign issuers has been noted by others. See, e.g., FANTO \& KARMEL, supra note 21, at 32-33, 39; James L. Cochrane, Are U.S. Regulatory Requirements for Foreign Firms Appropriate?, 17 Fordham InTL. L.J. S58 (1994); Franklin R. Edwards, SEC Requirements for Trading of Foreign Securities on U.S. Exchanges, in Modernizing U.S. Securities Regulations 57 (Kenneth Lehn \& Robert W. Kamphuis, Jr. eds., 1991) (noting that there had been no growth in the total number of foreign issuers listed on the U.S. exchanges and NASDAQ since the imposition of the Exchange Act's periodic disclosure regime on new NASDAQ issuers, despite the rapid growth in the trading of foreign securities); Greene et al., supra note 12; Roberta S. Karmel \& Mary S. Head, Barriers to Foreign Issuer Entry into U.S. Markets, 24 Law \& Poly. Intl. Bus. 1207; Romano, supra note 15, at 2419.

158. A number of commentators agree that the securities industry and the stock exchanges will pressure U.S. officials to adopt disclosure rules that maximize volume. See, e.g., FANTO \& KARMEL, supra note 21, at 5; Choi \& Guzman, National Laws, supra note 9, at 1874. 
States is the residence of a large portion of their most likely potential investors. Hardly any U.S. issuers have chosen to do so. ${ }^{159}$ The converse of this proposition is that for many foreign issuers, avoiding the U.S. market often does make sense given the burden of compliance. In fact, only about 700 out of about 28,900 foreign public issuers have chosen to comply with U.S. requirements. ${ }^{160}$

The analysis below suggests that this picture is likely to change. The trends toward globalization will decrease the advantages to U.S. issuers who choose to have their shares sold or traded in the U.S. market and increase the advantages to foreign issuers making the same choice. Thus, if the U.S. disclosure requirements are kept the same, the shares of more foreign issuers and fewer domestic issuers will be sold and traded in the United States. The net effect of the trend toward globalization on the volume of transactions effected in the United States is ambiguous. We will see, however, that the effect on issuer sensitivity to the U.S. level of disclosure is unambiguously positive. This means that as the trend toward globalization progresses, a given relaxation of standards would lead to a greater and greater increase in the volume of transactions effected in the United States and in the resulting gain in the rents to persons whose welfare depends on this volume. Thus the political pressures to relax these standards will grow. ${ }^{161}$

\section{The Impact of the Global Diffusion of Financial Information}

The increasing global diffusion of financial information is going to diminish the information disadvantage that investors everywhere

159. See supra note 45 .

160. According to the International Finance Corporation's annual survey of world stock exchanges, the total number of listed domestic companies worldwide in 1995 was 36.572 . See International Finance Corporation, supra note 2, at 23. Of these companies, 10,884 were in the world's developed markets outside of the United States; 7,671 were U.S. companies. See id. As of September 1995, there were 602 SEC-registered and reporting foreign companies listed on the New York Stock Exchange, the American Stock Exchange, and NASDaQ. See James L. Cochrane et al., Foreign Eouities and U.S. Investors: Breaking Down the Barriers Separating Supply and Demand 10 (New York Stock Exchange Working Paper No. 95-04, 1995). One hundred registered and reporting foreign companies were trading over-the-counter. See $i d$ at 10 n.8. Another 1,173 unregistered foreign companies were trading over-the-counter, exempt from the SEC's reporting requirements under $12 \mathrm{~g} 3-2$ (b). See id. at 10 . The 242 foreign companies currently being traded on the New York Stock Exchange represent only about one-tenth of the overseas companies that could meet the Exchange's listing qualifications. See id. at 2.

161. A number of academics and practitioners believe that the SEC will eventually lower its standards in order to keep stock exchange and investment bank business in foreign securities from moving abroad. See, e.g., Fanto \& Karmel, supra note 21. at 5; Bevis Longstreth, A Look at the SEC's Adaption to Global Market Pressures, 33 Col. J. Transnatl. L. 319 (1995). It is significant that Congress seems to be pressuring the SEC to react in just this fashion. See supra note 148 . 
face with regard to issuers from countries other than their own. In order to analyze the impact of this trend on the level of trading in the United States and on pressures to reduce the rigor of the U.S. regime, we need to separate it out from the impact of the other major component of the trend toward globalization - the reduction in the cost and difficulty of effecting orders abroad. To do this, assume for now that it is impossible to effect orders abroad: all initial purchases and subsequent secondary trades by U.S. residents occur in the United States. In such a world, a policy of U.S. investor protection and one of U.S. market protection are completely coextensive. An issuer, whether U.S. or foreign, will have to comply with U.S. disclosure rules to have a significant number of U.S. resident investors. The larger the number of the world's issuers that choose to comply, the larger the total volume of transactions effected in the United States. ${ }^{162}$

The following picture emerges, as demonstrated more rigorously in the model in Appendix I.

\section{a. United States issuers.}

Today, with the current incomplete level of global diffusion of financial information, almost all publicly traded U.S. issuers choose to comply with U.S. disclosure rules and have their securities sell and trade in the United States. They are less well known abroad, and thus their share price would suffer significantly if they relied exclusively on a foreign investor pool. The sacrifice that would be involved is sufficiently great that the burden of compliance with the U.S. regime is worthwhile. Relaxing U.S. standards to lower this burden of compliance cannot add to the volume of transactions effected in the United States by bringing U.S. issuers home, because almost all U.S. issuers are at home already.

What will happen in the future as we move toward full global diffusion of financial information? If current disclosure standards are maintained, the near universal compliance by publicly traded U.S. issuers is likely to cease. Exclusive reliance on foreign investors will entail less of a price disadvantage, and a significant number of U.S. issuers will find it worth the sacrifice of having no U.S. investors in order to be freed of the burden of complying with the

162. Implicit in this analysis is the assumption that if U.S. residents have made available to them the shares of a greater array of the world's issuers, they will both save more and invest a larger portion of their savings in equities. This seems plausible given the significant improvement in equity investing's tradeoff between risk and return that can be attained through international diversification. See Fox, Disclosure in a Globalizing Market, supra note 1 , at $2509-12,2523-25$. 
U.S. regime. Their shares will not sell or trade in the U.S. and thus the volume of transactions effected in the U.S. will suffer. Unlike now, relaxation of U.S. disclosure standards would prevent some or all of this loss of issuers.

\section{b. Foreign issuers.}

Today, with the current incomplete global diffusion of financial information, only a small percentage of foreign issuers comply with U.S. disclosure requirements. The others know that if they were to comply, the demand for their shares would be higher because then, in addition to their shares being sold and traded at home, they could also be sold and exchanged or NASDAQ traded in the United States. ${ }^{163}$ The resulting price advantage derived from access to U.S. investors is not, however, as great as it is for U.S. issuers because foreign issuers are less well known among U.S. investors. These noncompliers have calculated that this smaller price advantage is not large enough to justify the burden of complying with the U.S. regime. However, the existence of some foreign issuers that do comply under current standards suggests the existence of others that do not, but are at the margin. If today the U.S. standards were relaxed, thereby reducing this burden, the number of foreign issuers complying would, unlike with U.S. issuers, increase.

What will happen in the future as we move toward full global diffusion of information? The price advantage to foreign issuers of having access to U.S. investors will increase. If U.S. disclosure standards are maintained at current levels, an increasing number of foreign issuers will find that the price advantage of having U.S. investors has become sufficiently large to be worth the burden of compliance. ${ }^{164}$ If the standards were relaxed, the increase in the number of foreign issuers would be that much greater. This means that a lowering of U.S. standards, whether now or after further global diffusion of information, would increase the number of foreign issuers complying and hence the volume of transactions effected in the United States.

163. Any issuer trading on a U.S. exchange must comply. Any issuer not currently trading on NASDAQ that wishes now to start such trading much comply also. See supra notes 36-49 and accompanying text.

164. These trends are already in place. In the period $1986-96$, there has been a general increase in foreign issuer common stock listings on both the New York Stock Exchange and NASDAQ, particularly in the latter part of the period. See FANTO \& KARMEL, supra note 21, at $18-23$. 


\section{c. Aggregate effects.}

If U.S. standards are maintained at current levels, a move toward full global diffusion of financial information will decrease the number of U.S. issuer share transactions effected in the United States and increase the number of foreign issuer ones. The net effect is ambiguous. Relaxing U.S. disclosure requirements right now would result in a greater number of issuers choosing to access the U.S. market than do so under the current requirement. Relaxing U.S. disclosure requirements in the future, when financial information becomes more globally diffused, would have a larger positive effect. Today it would only increase the number of foreign issuers choosing the U.S. market, whereas in the future it would increase the number of both foreign and U.S. issuers making that choice. Thus the future's greater global diffusion of information will increase the pressure by the securities industry to lower U.S. standards because the gains to its members from such a lowering will be greater than they are today.

\section{Reductions in the Cost and Difficulty of Effecting Transactions Abroad \\ a. Irrelevance of reductions in cost and difficulty under a perfectly implemented exclusive investor residency approach to statutory reach.}

Analyzing the impact of the reduction in the cost and difficulty of effecting orders abroad - the other component of the trend toward globalization - requires being very specific in describing the U.S. approach to statutory reach and how it is implemented. If the United States were to adopt an exclusive investor residency approach to statutory reach and to implement it perfectly (i.e., did not rely on evidence concerning where transactions in an issuer's shares occur as proxy for the residency of the shares' buyers), a reduction in the cost and difficulty of effecting transactions abroad would have no effect on the pressures for a lower U.S. standard because imposition of the U.S. regime would in no way depend on the location of transactions in an issuer's shares. In that situation, only the increasingly global diffusion of information would have an effect on pressures to lower the U.S. standard and the analysis in the immediately preceding section would describe the whole story. Any issuer wanting to have a significant number of U.S. buyers or holders would have to comply with the U.S. regime regardless of whether or not it was selling its shares in the United States or promoting 
their secondary trading there. Therefore it might as well do so since there would always be some loss of potential U.S. investors if the shares were not offered in the United States or traded there, even after the substantial reductions in the cost and difficulty of purchasing securities abroad. As in the analysis above, an issuer's decision that it is worth incurring the burden of compliance to have access to the pool of U.S. investors is therefore tantamount to a decision to offer its shares in the United States and have them trade there.

\section{b. Effects of reductions in cost and difficulty under the current approach to statutory reach.}

In reality, however, the United States does not rely exclusively on the investor residency approach to statutory reach. Investor protection does not reflect the exclusive rationale guiding U.S. policy as to statutory reach; market protection concerns are involved as well. ${ }^{165}$ Even if investor protection were the exclusive rationale, perfect implementation of an approach based on such a goal is difficult because the residence of the parties to a share transaction is not easily monitored. Also, the investor residency approach, applied with sufficient rigor, would create problems with other countries. A country's issuers, while having a fairly direct and powerful ability to control the geographic location of trades in their shares, have less control over the residence of persons initially buying publicly offered shares and little control over the residence of subsequent purchasers. Thus they could easily become subject to the U.S. regime even though they took no steps to encourage U.S. investors beyond becoming a public company through primary share sales occurring in their own country.

The U.S. approach, therefore, includes a component of transaction location as well. ${ }^{166}$ This creates incentives for issuers to avoid the United States. As it becomes cheaper and easier for U.S. investors to effect transactions abroad, these incentives increase. Issuers are no longer foregoing as much of the U.S. pool of investors if their shares are only offered, or traded, abroad and so the sacrifice from only being public abroad is less. In a certain portion of cases, the fact that an issuer's shares are being sold or traded only abroad will tip the balance and the U.S. regime will not be applied. The lowering of the sacrifice associated with having shares sold or offered only abroad will induce more issuers, both U.S. and foreign,

165. See supra note 25 and accompanying text.

166. See supra Part I. There is also a component of issuer nationality in the current U.S. approach, but that does not add to these incentives. 
to choose that route. That will reduce the volume of transactions effected on U.S. markets relative to what it would be absent the United States using place as a factor in determining whether to apply its regime.

The ultimate question again concerns the political pressures on U.S. officials to relax the U.S. regime's required level of disclosure. To figure out how reductions in the cost and difficulty of effecting transactions abroad, when added to the further globalization of financial information, will affect these pressures requires a comparison of the positions today and in the future of both U.S. and foreign issuers.

$i$. U.S. issuers. Suppose first that the United States continues to maintain its current high level of required disclosure. We just saw that while almost all U.S. issuers today comply with the U.S. regime, this will change with further globalization of financial information. Foreign demand for U.S. issuer shares will increase. With this increased demand, even if it were impossible for U.S. investors to effect transactions abroad, some U.S. issuers will find the sacrifice involved in avoiding the sales and trading of their shares in the United States sufficiently reduced to be worth enduring in order to avoid the burden of U.S. disclosure regulation. ${ }^{167}$ When we take account of the additional facts that in reality it is possible for U.S. investors to effect transactions abroad and that the cost and difficulty of doing so will go down, we can expect even more U.S. issuers to make this choice since doing so will not force them to give up completely access to the pool of U.S. investors, as we had assumed in the analysis above.

Now suppose that the U.S. at some point lowers its level of required disclosure. Lowering the required level of disclosure today will still have no immediate effect, just as we determined in the analysis in the section above focused solely on global information diffusion. Again, almost all public U.S. issuers currently comply and so there are none to be attracted home by a relaxation of standards. Lowering the required level of disclosure in the future, however, which we determined in the prior analysis would increase the number of U.S. issuers staying home, would have an even bigger effect once we account for the reduction in the cost and difficulty of

167. As long as the issuer incorporates abroad, focuses its public offerings abroad, and is not (and, through secondary trading, does not become) more than $50 \%$ beneficially owned by U.S. residents, the issuer would not need to supply any more information than that required of it by foreign authorities. See supra sections I.A.2.a; I.B.2. 
effecting transactions abroad. With these reductions, less of a transformation in an issuer's investor pool is needed to avoid having any transactions in its shares occurring in the United States and thus a greater percentage of U.S. issuers would be on the margin as to whether or not to make this choice. A given lowering of U.S. standards will persuade a larger number of U.S. issuers to stay home who would otherwise choose to be public only abroad. Thus adding to the analysis globalization's second component - the reduction in the cost and difficulty of effecting transactions abroad - suggests that globalization will have an even greater effect on future U.S. issuer sensitivity to a lowering in U.S. standards.

ii. Foreign issuers. We saw in the analysis in the section above focusing solely on global information diffusion that today some foreign issuers comply with the U.S. regime in order to have their shares offered and traded in the United States and more would do so if the U.S. disclosure requirements were lowered. The foreign issuers that choose to comply do so because they wish to eliminate the additional costs and difficulties that U.S. investors would otherwise experience effecting transactions in their shares. If there were further global diffusion of financial information but no easing of the cost and difficulty of effecting share transactions abroad, U.S. investor demand for foreign issuer shares would increase. As we have seen, that would increase the price gain to foreign issuers from having their shares offered and traded in the United States. More foreign issuers would think it worthwhile to endure the burden of complying with the U.S. regime and the volume of transactions in foreign issuer shares would increase. On the other hand, with an easing of cost and difficulty of effecting share transactions abroad but no further global diffusion of information, fewer foreign issuers would comply with the U.S. requirements since, in theory at least, they could have access to an increasing number of U.S. investors without complying. ${ }^{168}$

Thus, with the United States maintaining its current required disclosure level, the size and direction of the combined effect of increasing globalization's two components on the volume of foreign issuer transactions appear to be ambiguous. Resolving that ambiguity requires looking at the different stages in the trend: the "in-

168. Professors Fanto and Karmel surveyed substantial foreign issuers that choose not to list in the United States. Many mentioned that they felt no pressing need for such a listing because U.S. investors, at least the institutional ones, have shown a willingness to make purchases on these issuers' home markets. See FanTo \& Karmel, supra note 21, at 37. 
terim" stage, when global information diffusion has increased and effecting a transaction abroad is easier and cheaper than it is now but still significantly more difficult and expensive than doing so at home; and the "culmination" stage, when the differential in the ease and cost of effecting transactions has been greatly reduced and there is full global diffusion of financial information.

In the interim stage, the effect of the decreased cost and difficulty of effecting transactions abroad may be largely illusory. At this stage, U.S. investor demand for a foreign issuer's shares is really more potential than actual until the issuer attracts the interest of one or more U.S. analysts. The most likely candidate is an analyst associated with a firm making a market in, or that is a specialist for, the issuer's shares. No such firm is likely to exist unless the issuer's stock is offered or traded in the United States. ${ }^{169}$ Thus, the effect of the first component of the trend toward globalization the increasing diffusion of financial information - is likely to dominate. The preceding section's analysis of that component in isolation is thus a reasonable description of what will happen in the presence of both components of globalization. As analyzed above, there will be an increase in the number of foreign issuers whose shares are offered and traded in the United States even if U.S. disclosure standards are not lowered. And there is no strong reason to believe that foreign issuer sensitivity to a relaxation of U.S. disclosure standards will change in either direction.

As we approach the culmination of the trend, however, things will switch, with the second component predominating instead. When effecting a transaction abroad becomes almost as easy and cheap for a U.S. investor as effecting one at home, there is no reason for foreign issuers to put up with the burden of higher U.S. disclosure requirements to the extent that the U.S. does not use a perfectly implemented investor residency approach to statutory reach. This will be true no matter how much global diffusion of information has added to U.S. investor demand for their shares. In such a world, the analyst attention necessary to turn potential demand into actual demand is unlikely to continue to require trading on a U.S. market. Brokerage firms will become increasingly transnational. For most of the significant foreign issuers that choose to be traded only outside the United States, there will be at least one

169. Professors Fanto and Karmel surveyed foreign issers that obtained United States listings and found that numerous respondents listed attention from analysts as an important reason for the listing. See FANTO \& Karmel, supra note 21, at 31. 
brokerage firm making a market or being a specialist in its shares that has an analyst trusted by U.S. investors.

In discussing this culmination stage, we are assuming for the moment that U.S. disclosure standards remain unchanged and that transaction location continues to play its current role in determining application of the U.S. regime. Notwithstanding increases in U.S. investor demand for foreign issuer shares, the second component of the globalization trend will ultimately decimate the secondary U.S. trading of shares of foreign issuers that do not engage in primary offerings in the United States. ${ }^{170}$ Primary offerings in the United States would decline significantly also. ${ }^{171}$ Marginal reductions in the level of disclosure required by the United States would not help much, but a total elimination of the difference between the U.S. level and what is called for abroad would help a great deal. With a total elimination, the execution efficiency of U.S. markets and the residual cost and convenience advantages to U.S. investors from investing in shares offered or traded in U.S. markets would be sufficient to attract most significant foreign issuers to the United States.

iii. Aggregate Effects. In the interim stage, adding the reduction in the cost and difficulty of effecting transnational transactions to the increased global diffusion of financial information will enlarge U.S. issuer sensitivity to a relaxation of U.S. disclosure standards. It will not diminish foreign issuer sensitivity to such a relaxation. Thus the aggregate effect is that issuer sensitivity to the U.S. level of required disclosure, and hence the sensitivity of the volume of transactions effected in the United States, will increase even more with globalization than was suggested by the analysis in the section above, which only considered knowledge diffusion. Along with this larger increase in sensitivity will come a larger increase in political pressures to relax U.S. standards.

170. A foreign issuer that engages in a primary offering in the United States must thereafter provide periodic disclosure under Section 15(d) of the Exchange Act. Thus, as long as it is even slightly cheaper and more convenient for a U.S. investor to trade shares at home, any issuer that engages in such an offering might as well promote secondary trading of its shares in the United States.

171. Suppose that a foreign issuer during this culmination stage engages in a primary offering only abroad. Investors in the markets where the shares are offered know that U.S. investors will have easy access to its shares once secondary trading develops in those markets. This means there is greater potential secondary market demand for the issuer's shares than would be the case today when' U.S. investors do not have such easy access. The issuer's shares will therefore suffer less of a price penalty for being initially offered only abroad than would be the case today. 
In the culmination stage, adding the reduction in the cost and difficulty of effecting transnational transactions to the increased global diffusion of financial information will again enlarge U.S. issuer sensitivity to a relaxation of U.S. disclosure standards. The effect on the sensitivity of foreign issuers at the culmination stage is trickier. Many might be almost entirely insensitive to a minor reduction in the U.S. standard but very sensitive to a major reduction that takes the U.S. level all the way down to the level of other countries. In the absence of a switch to the issuer nationality approach, the political pressure will involve a mix of demands for a major reduction in U.S. requirements and demands for a move, as far as practical, away from transaction location type tests for determining statutory reach, i.e., toward a pure investor residency approach.

To the extent that the first element of the mix of demands succeeds, globalization will result in a radical reduction in U.S. disclosure standards. To the extent that the second element succeeds, the analysis of the effects of globalization goes back to the analysis in the section above, which was devoted to the pure effects of global diffusion of information. Under a pure investor residency approach, transaction location will not influence whether the U.S. regime is applied. Thus the reductions in the cost and difficulty of effecting transactions abroad will not matter. The residual cost and convenience advantages to U.S. investors from investing in shares traded in U.S. markets will be enough to attract to the United States any issuer that calculates that having U.S. investors is worth the burden of complying with the U.S. disclosure regime. Thus the effects of globalization are the same as if we were to assume that it is impossible for U.S. investors to effect orders abroad - the assumption of the analysis in the section above concerning the impact of global diffusion of information alone. That discussion concluded that globalization would increase the sensitivity of issuers to the U.S. disclosure level. Thus if pressures to move to a pure investor residency approach succeed, the move will, combined with globalization, increase the pressures to lower the U.S. disclosure level, though not necessarily as radically as if the pressures to move to a pure investor residency approach fail.

\section{c. Effects of a switch from exchange based trading to electronic trading.}

Today the shares of most, though not all, issuers of any significance are traded on a stock exchange such as the New York Stock 
Exchange or the Tokyo Stock Exchange. ${ }^{172}$ It is possible, however, that in the next decade or so the shares of most or all such issuers will be traded not on stock exchanges but instead electronically via computer. ${ }^{173}$ The irrelevance of the place where a transaction is

172. In the United States, for example, the market capitalization of the approximately 2,675 issuers listed on the New York Stock Exchange was $\$ 6.01$ trillion in 1995 . See NEW York Stock Exchange Fact Book 42 (1996). This still dwarfs non-exchange based trading. At the end of 1994, the market capitalization of the New York Stock Exchange was roughly three and one half times the capitalization of all other equity markets in the United States including NASDAQ. See 1995 SEC AnN. ReP. 154; NASDAQ Fact Book 1 (1996). Non-exchange-based trading facilities, most notably the NASDAQ, are posing increasing competition, however. In 1995. the New York Stock Exchange held $50.2 \%$ of the annual dollar trading volume of U.S. equity markets ( $\$ 3.08$ trillion) while the NASDAQ captured $39 \%$ of the U.S. market (\$2.40 trillion). See NASDAQ Fact BOOK, supra, at 8; New York STOCK Exchange FACT BoOK, supra. at 13.

A stock exchange maintains a trading floor at a single physical location. Buyers and sellers, wherever located, place orders through brokers that send them to the exchange floor representatives who in turn participate in some form or other of auction for the stock in question. See 5 Louts Loss \& Joel Seligman, Securities Regulation 2506 (1990). On some exchanges such as the New York Stock Exchange, members may make "upstairs" trades off the floor of the exchange if (1) the stock was listed on or after April 26, 1979, or (2) a member is executing a block trade $(10,000$ or more shares or a market value of $\$ 200,000$ or more) as an agent for the buyer or seller, but not both. See id. at 2576 n.266; Rule 390 , N.Y.S.E. Guide (CCH) $\mathbb{}$ I 2390 (prohibiting members from trading listed stocks in over-thecounter markets, i.e., off the exchange floor); Regulation 19c-3, 17 C.F.R. $\$ 240.19 \mathrm{c}-3$ (1996) (allowing members to trade listed stocks over the counter, provided the stock became listed after April 26, 1979); Regulation 19c-1, 17 C.F.R. $\$ 240.19 \mathrm{c}-1$ (allowing off the board trading for a block positioner acting as an agent for either the buyer or the seller); Rule 127, N.Y.S.E. Guide $(\mathrm{CCH})$ II 2127 (block trading).

Thus, as a general matter each trade in an exchange listed stock trade has a physical place where execution occurs, and, in that sense, can be said to occur in a particular, identifiable nation. And while the issuer's stock may be listed on more than one exchange, typically the bulk of trading occurs at just one of them. In the case of a stock with a multiple listing, the exchange that starts with the largest volume of trading has the self-perpetuating advantage of continuing to be the most attractive place to trade because it offers the greatest liquidity. See Morris Mendelson \& Junius W. Peake, Electronic Execution Systems: Myth vs. Realiry 1, 2 (University of Pa. Inst. for Law \& Econs. Discussion Paper No. 93, 1990). This tendency for investors to confine their trades to the exchange with the largest volume is illustrated by the fact that where computer links have been established between two exchanges in the same time zone, for example between the American Stock Exchange and the Toronto Stock Exchange, orders for stocks listed on both exchanges have tended to flow primarily in one direction, toward the "primary" exchange (the more established exchange for trading the issuer's stock). See William C. Freund, Electronic Trading and Linkages in International Equity Markets, Fin. Analysts J., May-June 1989. at 11-12. Where the links have been between exchanges in different time zones, orders made during the hours that the primary exchange has been closed tend to be offset only against pre-existing quotations from the primary exchange. See id.

173. It is a matter of debate whether this current exchange-based structure of secondary trading will continue into the foreseeable future or whether there will be a move to electronic trading. Exchange trading and computer trading are each institutions that centralize order flow. Computer trading has a number of advantages: easy investor access from anywhere through computers with real time displays of bids, offers and volume, low cost of operation, and ease of transaction reconstruction leading to more reliable clearance and settlement and more effective enforcement of regulations. A number of observers predict that the replacement of exchange trading by computer trading is probable or at least possible. See Mendelson \& Peake. supra note 172; Joseph A. Grundfest, Internationalization of the World's Securities Markets: Economic Causes and Regulatory Conse. QUences - OR - Beware the Uber-Regulator 19-20 (Stanford Law and Econimics 
effected for the question of what country should regulate an issuer's disclosure would then become transparent. The computer might actually match purchase and sale orders (like the CATS program currently operated by the Toronto Stock Exchange and several others), or it might simply provide the bid and offer prices of market makers and facilitate execution once a broker has chosen with which market maker to deal (as NASDAQ does domestically today). ${ }^{174}$ Either way, though, it would be impossible to say there is any particular location where the transaction is effected. ${ }^{175}$ Such a development would absolutely require elimination of transaction location-type tests for determining statutory reach. If there is no switch to the issuer nationality approach, the only approach left is investor residency. The analysis would then follow that of the section above that focuses solely on the global diffusion of financial information. In that discussion, we assumed that any issuer wishing access to a significant number of U.S. investors would need to register under the U.S. regime. The conclusions there that globalization will increase the sensitivity of issuers to the U.S. disclosure level and hence increase pressure to lower U.S. requirements would therefore apply also to a world dominated by computer trading. ${ }^{176}$

Working Paper, 1990); Therese H. Maynard, What is an "Exchange?" - Proprietary Electronic Securities Trading Systems and the Statutory Definition of an Exchange, 49 WASH. \& LEE L. Rev. 833, 862 (1992).

The key question is whether a computer trading system can provide liquidity comparable to one based on specialists operating on an exchange floor. See Freund, supra note 172, at 12-14; Lewis D. Solomon \& Louise Corso, The Impact of Technology on the Trading of Securities: The Emerging Global Market and the Implications for Regulation. 24 J. MARshall L. REv. 299, 318-19 (1991). There are real questions as to whether specialists in fact provide such liquidity, however, since their obligation to do so is vague and the capital at their disposal is small compared to the largest traders. See Jonathan Macey \& Hideki Kanda, The Stock Exchange as a Firm: The Emergence of Close Substitutes for the New York and Tokyo Stock Exchanges, 75 Cornell L. Rev. 1007, 1026-34 (1990). Macey and Kanda point out that the Tokyo Stock Exchange essentially works without specialists who attempt to provide liquidity since the "satori" firms, the ones that most resemble specialists, act as pure conduits that match buy and sell orders and are not allowed to trade on their own account in the stocks assigned to them. See id. at 1043-44. Macey and Kanda speculate that the functions that the satori firms do provide could be largely done by computer. See id. at 1046.

174. See Mendelson \& Peake, supra note 172, at 2-3; Solomon \& Corso, supra note 173 , at $309-22$. at 330

175. This problem has been noted by others. See, e.g., Solomon \& Corso, supra note 173,

176. See supra section VI.B.2. In such a world, the fortunes of the U.S. securities industry would depend on the volume of shares purchased and traded by U.S. investors, which would increase if the shares of more foreign issuers were made available to them. See supra note 162. 
VII. How the Increasing Pressures Under the Investor Residency and Location of Trade Approaches to Lower the Level of U.S. Reguired Disclosure Can Lead to Suboptimal Regulation

\section{A. How Increased Pressure to Lower U.S. Disclosure Standards May Succeed Even If It Lowers National Welfare}

We have just seen how, if the United States fails to switch to the issuer nationality approach to statutory reach, further globalization will create stronger political pressures to relax U.S. disclosure standards. That conclusion is only a cause for concern, however, if there is reason to believe that the pressures will succeed and the result will be a level of required disclosure that lowers U.S. economic welfare. What follows is a story of how this might well happen even if the U.S. political system functions in a way that attempts to maximize the interests of its residents.

\section{The Quest for Rents and the Adoption of an Inefficiently Low Required Disclosure Level}

The starting point to this story is to differentiate between two different concepts of what is the optimal level of required disclosure. The first concept, "substantive optimality," is the level at which the marginal social costs of disclosure just equal its marginal social benefits in terms of efficient allocation of capital and reduction in the agency costs of management. The second concept, "total optimality," adds to this the effect of the level chosen on the rents of persons whose welfare depends on the volume of transactions effected in the United States, such as those associated with the securities industry or the stock exchanges.

In an entirely domestic economy, the two concepts are identical since the level of required disclosure should have no effect on the volume of transactions effected. The introduction of transnational securities transactions, however, permits a divergence. As we have seen, with our current approach to statutory reach, a relaxation of the level of required disclosure would increase the volume of transactions effected in the United States and the size of this potential increase will grow as globalization proceeds. ${ }^{177}$ It is perfectly possible that the resulting welfare gains to those whose welfare depends on volume would exceed the resulting losses to entrepreneurs and labor from the decrease in the economy's efficiency. In that event,

177. See supra sections IV.B; VI.B.2.c; VI.B.3.b. 
the totally optimal level of required disclosure would be lower than the substantively optimal one. This lower, totally optimal level will be the one adopted by a political system that attempts to maximize the interests of its citizens but continues to operate under the constraint of the current approach to statutory reach.

Operating under this constraint is unfortunate. A switch to the issuer nationality approach would permit retention of the substantively optimal level of required disclosure, thereby maximizing the welfare of entrepreneurs and labor, while still permitting persons whose welfare depends on volume to maximize their rents.

\section{The Race to the Bottom}

The problems with failing to switch do not end here, however. We need to take account of likely foreign reaction to the relaxation of U.S. standards. When we do, we see a perfect example of a "race to the bottom" scenario in which the United States will ultimately end up with a substantively suboptimally low required level of disclosure and no greater rents for its financial industry than before the race started.

The scenario involves the classic "prisoner's dilemma" from game theory. The countries would maximize their joint welfare by respectively adopting their substantively optimal levels of required disclosure. The problem is that for each, the dominant position in the game is to adopt a lower level. Each is better off adopting the lower level whatever the other country does. The result is an equilibrium in which both are worse off.

The scenario, more formally set out in Appendix II, posits two countries, $A$ and $B$, each initially having an entirely domestic economy with no transnational securities transactions possible. Each chooses the level of required disclosure that is substantively optimal for it. Then transnational securities transactions become practical. Country $A$ lowers its disclosure level, seeing that by doing so, a larger volume of transactions will be effected within its borders and that the resulting increase in rents exceeds the welfare declines from having a substantively suboptimal disclosure level. Country $B$, as a result, faces a welfare decline because of the loss to Country $A$ of transactions that would otherwise have been effected within $B$ 's borders. Country $B$ then lowers its disclosure level, seeing that by doing so it can recapture the lost transactions and that the rents from the recaptured transactions exceed the welfare decline from it also switching to a substantively suboptimal disclosure level. Each country has now suffered the welfare loss from having a substan- 
tively suboptimal disclosure level and in the end does not receive any compensating increase in rents. The result would be the same if $B$ moved first. The result is an equilibrium because for each country the lower level of required disclosure is the dominant strategy: it is better off choosing the lower level whatever the other country chooses.

\section{B. The Appropriateness of Assuming Current U.S. Disclosure Standards Are Optimal and the Question of Regulatory Competition}

The discussion in Part VI shows that maintaining the current U.S. approach to statutory reach will result in increasing political pressure to relax the U.S. disclosure regime as the market for securities globalizes further. The same would be true of other countries using this approach. The current approach permits an issuer to influence which disclosure regime will govern it through its choice of where its shares are going to be offered and traded. The United States and each other country wishes to maximize the volume of transactions effected in its own market, thereby increasing the rents earned by its residents. It would thus endeavor, everything else being equal, to set its level of required disclosure to attract as many issuers as possible. The rewards for doing so will intensify as globalization proceeds. Such an endeavor is inherently competitive since a gain in transaction volume by one country can only come from a loss by another. Switching to the issuer nationality approach would stop this competition.

I concluded in Parts III and IV that the issuer nationality approach is superior to the current U.S. approach to statutory reach because it selects more discriminatingly which among the world's issuers have disclosure practices that affect primarily the welfare of U.S. residents and which primarily the welfare of residents of other countries. U.S. officials have greater expertise than foreign officials about the tradeoffs between the costs and benefits of the disclosure behavior of the issuers so selected. They are also politically responsible to the people most affected by these issuers' disclosure behavior. Thus, for these issuers, the level of disclosure selected by U.S. officials is likely to be closer to what is optimal than the level selected by officials of any other country.

This preliminary conclusion, however. is based on the simplifying assumption that the choice of approach to the reach of the U.S. regime would have no effect on the level of disclosure that U.S. officials select. As discussed in these last two Parts, this assumption 
is not entirely accurate. Retaining the current approach will lead to intensifying regulatory competition, whereas a switch to the issuer nationality approach will terminate such competition. Thus, coming to a final conclusion about the best approach to statutory reach requires us to address the potential effect of regulatory competition on the overall analysis. ${ }^{178}$

The race to the bottom model presented above suggests that the effect of regulatory competition on U.S. welfare is bad, thus reinforcing the conclusion in Parts III and IV. The model shows that globalization's increasing pressure to lower U.S. disclosure standards can result in a level below what is substantively optimal. The model is premised, however, on the U.S. political system acting to maximize the interests of its residents. Accordingly, we would expect that the system, prior to significant influences from transborder transactions, would choose a level of required disclosure for entirely domestic issuers that is an unbiased estimate of what is optimal in terms of U.S. economic welfare. This premise suggests that the current level is substantively optimal since it was largely established in such an era. I argue below that this is a reasonable premise for a study of this type. I also argue that even if this premise turns out to be incorrect, the likely reasons for its inaccuracy do not mean that we should revise the preliminary conclusion that a switch to the issuer nationality approach would increase U.S. economic welfare.

178. Professors Choi and Guzman, for example, extol the benefits that competition among securities regimes could bring. They state, "competitive pressures between regimes [lead] to beneficial results as countries compete for both issuers and investors." Choi \& Guzman, Dangerous Extraterritoriality, supra note 9, at 223. Such pressures, in their view, "restrain[] the ability of regulators to pursue their own bureaucratic goals or cater to specific industry interests." Id. at 227.

Romano is similarly enthusiastic, stating that "[a]s a competitive legal market supplants a monopolist federal agency in the fashioning of regulation, it would produce rules more aligned with the preferences of investors, whose decisions drive the capital market." Romano, supra note 15 , at 2362. She takes as her model state competition for corporate charters, which she characterizes as "a responsive legal regime that has tended to maximize share value." Id. at 2362; see also Roberta Romano, The Genius of American CorpoRATE LAW (1993).

The proposition that state competition for corporate charters enhances U.S. economic welfare is in fact a controversial one and has been the subject of one of corporate law's most intense debates in the last 20 years. See Fox, Empowering Issuers, supra note 15, at 15-26 for a discussion of this controversy

Moreover, even if Romano is correct that state competition for corporate charters is share-value maximizing, Romano overstates her case when she says that "there is no reason to expect state competition to operate differently for securities law than corporate law." RoMANO, supra, at 2585 . Unlike a firm's decision to include certain corporate governance terms through its choice of where to incorporate, a firm's decision to commit to a higher level of disclosure, through a securities regime choice, has positive externalities. See supra section IV.A.2. This can have a crucial effect on the workings of regulatory competition. See Bebchuk, supra note 112 , at 1490-91. 


\section{A Preliminary Consideration}

One consideration should be noted at the outset. If regulatory competition is desirable, the reason is because, without it, the U.S. would require too much disclosure, not too little. With the current U.S. approach to statutory reach, if the United States lowers its disclosure requirements, more issuers are likely to promote the sale and trading of their shares there. This flows from the fact, as established in Part IV, that issuers with privately optimal disclosure levels below U.S. requirements - the substantial majority - will be deterred from the U.S. market, but issuers with privately optimal levels at or above the U.S. requirements will not be attracted by the strictness of the U.S. regime. They will be there already. Thus the engine of regulatory competition under the current U.S. approach - the desire to maximize the number of transactions effected in the United States - creates pressure to lower the country's required level of disclosure.

\section{The Starting Presumption: For Regulating Each State's Entirely Domestic Activities, Its Rules Are Superior to Those of Any Other State}

Where, as here, the issue under study is how to regulate a given kind of behavior with transborder effects, it is conventional to presume that countries act in their own best interests when regulating entirely domestic versions of the same behaviors. ${ }^{179}$ This conclusion seems a reasonable starting presumption in the construction of a positive theory of such behavior and its regulation. Everything else being equal, a simpler model is preferred to a more complicated one. A model on the international plane must in any event take account of interactions that one on the domestic plane does not, and so there is a greater premium for parsimony in the description of what goes on within each state. Thus the government of each country is assumed to act in the country's own best interest rather than in accord with some more complicated theory of gov-

179. This. for example, is a fundamental assumption behind the governmental interest method for identifying "true conflicts" of law. See William F. Baxter, Choice of Law and the Federal System, 16 STan. L. Rev. 1 (1963); Larry Kramer, Rethinking Choice of Law, 90 Colum. L. REv. 277 (1990). 
ernmental behavior ${ }^{180}$ such as public choice theory. ${ }^{181}$ Under this assumption, as just discussed, the current level of U.S. required disclosure is optimal. Given this, it would be a mistake for the United States to maintain the current approach to statutory reach as globalization proceeds. If it does so, as demonstrated in Part VI, the political pressures to lower U.S. standards will increase. As shown in the first section of Part VII, these pressures can succeed even though the government tries to act in the country's best interests. The resulting level of welfare is lower than what would prevail under the issuer nationality approach. Moreover, when the reactions of other countries are taken into account, a race to the bottom develops, leaving the United States even worse off.

What, though, would be the implications of incorporating the more complicated public choice theory of governmental behavior into the analysis? Public choice theory suggests that concentrated interest group action will cause a country to regulate more than is in its national interest. Public choice theory, applied within a purely domestic context, has in fact been used by some commentators to suggest that mandated disclosure represents overregulation at the behest of the securities industry. ${ }^{182}$ As a result, the required level of disclosure is, in their view, suboptimally high. If these commentators are correct, regulatory competition might be a useful counter force. Such a conclusion would cut against my preliminary conclu-

180. Economists can appreciate this point by considering the following analogy. Here we are constructing a theory of statutory reach with respect to transborder interactions and make the assumption that nations regulate entirely domestic interactions of the same kind in a welfare maximizing way. We do this to help prevent the model from becoming overly complicated, notwithstanding the existence of public choice theory, a respectable, albeit controversial, theory of domestic regulation that suggests otherwise. Economists do the same kind of thing. In constructing the orthodox theory of industrial organization, for example, they assume that firms - the component parts of each industry - act to maximize share value, see, e.g., F.M. Scherer \& David N. Ross, Industrial Market Structure and Economic Performance 38-39 \& n. 43 (3d ed. 1990) (collecting studies), notwithstanding the existence of respectable, albeit controversial, theories of the firm that they do not. For examples of theories of the firm not based upon profit maximization, see WILLIAM J. Baumol, Business Behavior, Value and Growth 45-52 (rev. ed. 1967); Oliver E. Williamson, The Economics of Discretionary Behavior (1964); Robin Marris, $A$ Model of the "Managerial" Enterprise, 77 Q. J. of ECon. 185 (1963); Herbert A. Simon, Theories of Decision-Making in Economics and Behavioral Science, 49 AM. ECON. REv. 253 (1959).

181. For examples of public choice theory, see James M. Buchanan \& Gordon Tullock. The Calculus of Consent: Logical Foundations of Constitutional Democracy (1962); William A. Niskanen, Jr., Bureaucracy and Represent attve GovERnMENT (1971): Richard A. Posner, Theories of Economic Regulation, 5 Beil J. Econ. \& MGMT. SC. 335 (1974); George J. Stigler, The Theory of Economic Regulation, 2 BELL J. Econ. \& Mgat. SCI. 3 (1971).

182. See Susan M. Phillips \& J. Richard Zecher, The SEC and the Public InterEST 22-23 (1981): Jonathan R. Macey, Administrative Agency Obsolescence and Interest Group Formation: A Case Study of the SEC at Sixty, 15 CARdozo L. Rev. 909, 922 (1994). 
sion in Parts III and IV that a switch to the issuer nationality approach would increase U.S. welfare, since the issuer nationality approach stifles regulatory competition. A desire to promote regulatory competition would suggest instead that we maintain the current approach to statutory reach or even adopt something more radical, such as a pure transaction location approach ${ }^{183}$ or an approach giving issuers the right to choose the disclosure regime by which they are governed irrespective of the issuer's nationality, the residence of its investors, or where its shares are offered or traded. ${ }^{184}$

Advocates of approaches intended to promote regulatory competition must, however, establish two things to overcome the conventional and reasonable presumption that states act in their own best interests. First, they need to show that within a purely domestic context, concentrated interest group action in fact results in too high a level of mandated disclosure. Second, assuming that it does, they need to show that regulatory competition at the international level would be a helpful antidote to the problem. Neither will be easy to show.

\section{The Public Choice Critique in the Purely Domestic Context}

Several factors cast doubt on the story that within a purely domestic context concentrated interest group actions result in too high a level of mandated disclosure. To start, there is debate about the effectiveness of public choice theory in explaining regulation generally. There is hardly a consensus that most political action consists of self-interested rent seeking. ${ }^{185}$ Moreover, even if one believes that public choice theory has considerable explanatory value generally, the story may err when applied to securities disclosure. The story does not correctly identify all of the interests of the securities industry. Some members may well desire a high level of mandatory disclosure in order to reduce their costs of collecting information. Others, however, may prefer a low level. For example, if only a low level is required, more firms would be willing to be public companies, thereby resulting in more fee-generating initial public offerings and secondary trades. The story also omits consideration of con-

183. See Choi \& Guzman, Dangerous Extraterritoriality, supra note 9, at 221-23.

184. See id. at 231-35; Romano, supra note 15.

185. For critical reactions to public choice theory, see Dorothy A. Brown, The Invisibility Factor: The Limits of Public Choice Theory and Public Institutions, 74 WAsH. U. L.Q. 179 (1996); Richard H. Pildes \& Elizabeth S. Anderson, Slinging Arrows al Democracy: Social Choice Theory, Value Pluralism, and Democratic Politics, 90 Colum. L. Rev. 2121 (1990); Cass R. Sunstein, Interest Groups in American Public Law, 38 Stan. L. Rfv. 29 (1985). 
centrated interest groups outside of the securities industry, such as the managements of established public corporations, whose interests are likely to favor low levels of required disclosure. ${ }^{186}$ Finally, it does not account for the possibility that the interests for more disclosure attributed to persons in the securities industry may serendipitously coincide with correction of important market failures in issuer disclosure due to the public goods nature of information and agency problems between the managements of established issuers and their stockholders. ${ }^{187}$ The actual beneficiaries of such a correction would, under public choice theory, be too diffuse to be politically effective.

\section{Even If the Public Choice Critique Is Valid in the Purely Domestic Context, Regulatory Competition Is Not Necessarily a Helpful Antidote}

Assume now that the public choice theorists' story is correct: within a purely domestic context, the forces they identify result in too high a level of required disclosure. That does not necessarily imply that promoting regulatory competition is a helpful antidote to the problem. Promoting competition means giving issuers some degree of freedom to choose the regime they prefer, i.e., maintaining the current approach to regulatory reach or something more radical. Issuer entrepreneurs and managers are the ones who will choose. ${ }^{188}$ Authorities in each country will thus try to have a required level of disclosure that is attractive to the entrepreneurs or managers of as many issuers as possible. Most U.S. issuers would therefore likely have the option of binding themselves to provide something close to their respective privately optimal levels of disclosure regulation. ${ }^{189}$

186. See supra sections IV.A.2.a; IV.A.2.b.ii.

187. See supra section IV.A.2. See also Coffee, supra note 10; Easterbrook \& Fischel. supra note 112 , at $684-85$.

188. See supra section IV.A.1.

189. The exact pattern of national regimes that would develop with regulatory competition is difficult to predict because the possible reactions of each country to the moves of each other country are complex. The final pattern could be a situation in which each country tries to satisfy the preferences of the entrepreneurs or managers of a different niche group of issuers, or it could be a situation in which each country converges on the same single level that would attract the maximum number of issuers. See Choi \& Guzman, National Laws, supra note 9, at 1869-82. Whichever occurs, entrepreneurs and managers drive the process, and, as we have seen, would prefer to bind their firms to a level of disclosure below the level that would maximize social welfare. See supra section IV.A.2. Thus the typical U.S. issuer will end up disclosing at a suboptimally low level.

It is useful to consider an example of the pattern of national regimes that might develop in a plausible world of the future if the recommended switch to an exclusive issuer nationality approach to statutory reach is not undertaken. Assume that it is still modestly more expen- 
Whether it is desirable to give U.S. issuers this option depends on a comparison of two ways in which society can choose the level at which each issuer discloses. One way - the way of regulatory competition - is to rely on the decisions of issuer entrepreneurs and managers, decisions based on their calculations of the benefits and costs privately experienced by them. The other - the way of the issuer nationality approach - is to rely on the decisions of the U.S. government, which represents the persons who primarily experience the actual benefits and costs of U.S. issuers' disclosures. In making this comparison, concern should be with how close the level chosen is to each issuer's socially optimal level, i.e., where the social marginal costs of the issuer's disclosure equals the social marginal benefits of its disclosure.

As we saw in Part IV, the entrepreneur and manager calculations of private benefit and cost are not likely to correspond closely to the social benefits and costs: private costs of disclosure are likely to be larger than social costs and private benefits less than social benefits. ${ }^{900}$ Thus their calculations will be biased: they will want to

sive and inconvenient for investors to place orders abroad. It is thus still more advantageous than not, everything else being equal, for an issuer to have its shares offered and traded in the United States, where there is a huge pool of potential investors. Suppose, in such a world, the United States lowered its level to just above the level of the next major capitalist country - the United Kingdom. As long as the United Kingdom does not raise its level to one above the reduced U.S. level, the United States would lose no old issuers, see supra section IV.B.2, and it would pick up a substantial number of new ones - those that find the old strict U.S level of disclosure too burdensome to be worth better access to U.S. investors but not the substantially less strict new U.S. level. It is very unlikely that the United Kingdom would in fact raise its standards above the reduced U.S. level. Doing so would prompt issuers with privately optimal disclosure levels above the new lowered U.S. level to register in the United Kingdom, but that would not add much to U.K. trading volume since such an issuer could also register without additional burden in the United States, which is a much larger market. It is much more likely that the United Kingdom, if it responds at all, would lower its required level too. This would pick up issuers with privately optimal disclosure levels below the lowered U.S. level that find better access to U.S. investors worth the U.S. disclosure burden if the next less strict regime of a country with an important market is only slightly less strict than the U.S. regime, but would not find such better access worth the U.S. disclosure burden if the next less strict regime is significantly less strict. If the U.K. did lower its level. the U.S. could further lower its level, again gaining more issuers. They might ratchet down together in this fashion. How far this would go would depend on the required level of the third most demanding country with a major market and its reactions, and so on, as well as the overall distribution of privately optimal disclosure levels among the world's issuers.

At the bottom there will probably be some small country, with little in the way of domestic issuers, offering a disclosure regime that requires essentially no disclosure. In other words, some country in its disclosure laws is likely to become the equivalent of Luxembourg in its banking laws. In fact, Luxembourg itself is already reputed to provide only a "nods and winks" review of offers and sales of new issues of securities listed on the Luxembourg Stock Exchange. See Manning Gilbert Warren III, Regulatory Harmony in the European Communities: The Common Market Prospectus, 16 Brook. J. INTL. L. 19, 41 (1990). How many issuers have privately optimal disclosure levels that low, however, is questionable and so we would not expect a major jurisidction to descend to this level.

190. See supra section IV.A.2. 
choose a regime requiring them to disclose less than is socially optimal. The public choice story is that the government has biases running in the opposite direction. One should not favor regulatory competition over the issuer nationality approach, however, unless one believes that the level chosen by the government is even more biased than the level required by the regimes chosen by legally unconstrained private entrepreneurs and managers. Few legal commentators (including those with a law and economics orientation) appear to hold the belief that issuer entrepreneurs and managers should be free to choose their own disclosure levels. ${ }^{191}$

\section{Public Choice Arguments for Not Promoting Regulatory Competition}

Adding a public choice component to the analysis of what approach to statutory reach is best may actually add to the overall strength of my conclusion that there should be a shift to an exclusive issuer nationality approach. As we have seen, with the regulatory competition prompted by the current approach, persons who receive rents dependent on the volume of transactions effected in the United States would, as globalization proceeds, forgo increasing amounts in rent if U.S. disclosure standards are not lowered. We have already seen how this can cause a government to lower standards when the gain in rents exceeds the welfare loss from having a substantively suboptimal level of required disclosure. Public choice theory suggests that the relaxation may occur even if these foregone rents from the United States not lowering its level are less than the welfare losses from the United States lowering its level - with U.S. issuers consequently disclosing at a less than optimal level in resource allocation terms. This is because the gainers are concen-

191. See supra note 112. Easterbrook and Fischel for example, conclude that the U.S. mandatory disclosure regime ought to be retained after explicitly considering public choice theory. See Easterbrook \& Fischel, supra note 112, at 684-85. Addressing a somewhat analogous problem within our domestic federal system of corporate and securities law-making, Lucian Bebchuk has argued that placing the regulation of corporate disclosure under the authority of state corporate law rather than federal securities law would. because of regulatory competition, result in a suboptimally low level of disclosure. See Bebchuk. supra note 112 , at $1490-91$.

Jonathan Macey, on the other hand, finds "[a]s markets have become more efficient, society's need to devote resources to support a statutory regime of mandatory disclosure designed and enforced by the SEC has disappeared. Any information that was supplied by the force of law now is supplied by the marketplace." Macey, supra note 182, at 928. The efficiency with which markets impound the information that issuers choose to release, however, is a different issue from the question of whether issuers will choose to release as much information as is socially optimal. Roberta Romano proposes a system by which issuers choose by which country's disclosure regime they wish to be bound. See Romano, supra note 15. A critique of her proposal is found supra in section IV.A.2. 
trated and more capable of political action than the losers, who are many but diffuse, and who each get just a little less because of efficiency losses from the way capital is utilized in the United States. There is thus no necessary inconsistency between a belief in public choice theory and the conclusion that in the context of a globalizing securities market, regulatory competition will result in each country having too low a level of mandated disclosure.

\section{Regulatory Competition and Differences Among U.S. Issuers in Their Socially Optimal Disclosure Levels ${ }^{192}$}

Allowing a U.S. issuer to choose its disclosure regime has another positive feature, not considered so far. This is its potential to accommodate differences among U.S. issuers in their socially optimal levels of disclosure. The potential accommodation would work as follows. First, the regulatory competition arising from issuer choice may lead to a differentiation in disclosure regimes across countries. Each issuer then may select the regime requiring the level of disclosure closest to its particular social optimum. This potential customizing of required disclosure is the reason that Professors Choi and Guzman support a transaction location approach to statutory reach. ${ }^{193}$

This potentially positive feature of the transaction location approach is, however, overwhelmed by its problems. To start, it is not at all clear that the regulatory competition arising from the transaction location approach would lead to a differentiated set of regimes. It might instead lead to all countries' standards converging toward the single level designed to attract the most issuers worldwide. ${ }^{194}$ If this happens, U.S. issuers will move from a standard designed for the average U.S. issuer to one designed for the average issuer worldwide. This movement is in the opposite direction from the customizing of disclosure requirements that Choi and Guzman hope the transaction location approach will bring.

192. I discuss the matters considered in this subsection more extensively in Fox Empowering Issuers, supra note 15, at 51-63.

193. See Choi \& Guzman, National Laws, supra note 9. at 1865-83.

194. Choi and Guzman acknowledge that such a convergence equilibrium is quite possible, particularly in a world in which countries possess natural advantages in retaining domestic issuers. See id. at 1879-81. The United States will still have such natural advantage, at least residually, for the foreseeable future, although, as discussed in Part VI, it will be weakening over time. As long as financial information is not fully globalized, U.S. investors will exhibit some bias toward investing in U.S. issuers. And as long as there is also some cost and convenience advantage to U.S. investors in investing in shares offered and traded in the United States, many U.S. issuers will make their shares available in U.S. markets so as not to put obstacles in the way of their largest, most natural group of investors. 
The second problem is that the persons choosing each issuer's disclosure regime will be its entrepreneurs or managers. As discussed at numerous points above, they have a bias toward choosing a level of required disclosure lower than the issuer's socially optimal disclosure level. ${ }^{195}$ Thus, even if a differentiated set of regimes is available and some country offers a required disclosure level just equal to the issuer's social optimum, the entrepreneurs or managers will instead prefer the regime of some other country with a lower required level of disclosure.

Two observations are in order with respect to this second problem. One, discussed in Part IV, is that the difference between an issuer's privately optimal level of disclosure and its socially optimal one is likely to be substantial. ${ }^{196}$ The other, discussed in Part V, is that there are important differences among issuers worldwide in terms of their socially optimal levels of disclosure that are significantly related to the nationalities of the issuers involved. These two observations combine to suggest that the transaction location approach's bias for underdisclosure will outweigh its capacity to accommodate individual differences among U.S. issuers, which typically are not great relative to differences between U.S. issuers and issuers from other countries. Thus, compared to the issuer nationality approach, the transaction location approach is likely to lead to a greater, not smaller, average deviation between each U.S. issuer's required level of disclosure and its socially optimal one. ${ }^{197}$

The third problem is that the transaction location approach would apply the U.S. regime to foreign issuers whose shares are offered or traded in the United States. The application of the U.S. regime to such foreign issuers would be harmful to U.S. interests, as discussed in Parts III and IV. ${ }^{198}$ For the foreseeable future, there will continue to be at least a residual cost and convenience advantage to U.S. investors from investing in shares offered and traded in the United States. This continued cost and convenience advantage means that some foreign issuers will register under the U.S. regime

195. See supra section IV.A.2.

196. See supra section IV.A.2.

197. Moreover, if the need to customize is important, the U.S. disclosure regime itself could attempt to accommodate differences among U.S. issuers in their socially optimal disclosure levels. It does so to some extent already in the primary offering disclosure area. Many offerings are granted exemptions based on the size of the offering, the number of investors or the wealth and sophistication of the investors. Many of these exemptions require some kind of disclosure, but at a lower level than what is required with conventional Section 5 registration. Small issuers can also use the simplified procedures and lower disclosure requirements under Regulation A.

198. See supra sections III.B.2; III.B.3; and IV.B. 
even though, for most, it requires more disclosure of them than is socially optimal, thereby creating foreign relations problems for the United States. All other foreign issuers of any significance will stay out of the United States solely because of the desire to avoid such registration. Their doing so will require U.S. investors either to incur extra cost and inconvenience or forgo an important range of investment opportunities. It will also reduce the incomes of U.S. residents whose rents depend on the volume of transactions effected in the United States. ${ }^{199}$

\section{Summary}

A switch to the issuer nationality approach has clear advantages. Compared to officials of the country where the sales or trades in a U.S. issuer's shares occur or the country where its investors reside, U.S. authorities have greater expertise concerning the resource allocation and risk reduction effects of the issuer's disclosure and greater political incentives to choose the right level. Moreover, U.S. officials receive more direct negative feedback if the level they choose is wrong. The only way to justify retention of the current U.S. approach to statutory reach - or a move to an approach giving issuers even more freedom choosing their regimes - is to show that the regulatory competition engendered thereby has benefits and that the benefits overwhelm the clear advantages of the issuer nationality approach. The case for such a showing is not persuasive.

The primary argument for permitting U.S. issuers to choose their disclosure regimes is based on the claim that the current U.S. domestic disclosure regime requires more disclosure than is good for us, a tendency that regulatory competition will counteract. This claim runs contrary to the conventional and reasonable starting presumption in studies concerning the regulation of behavior with transnational effects that countries' domestic regulations represent their own best interests. Equally important, a number of factors cast doubt on the proposition that in the particular area of disclosure, the United States tends to overregulate.

The conclusion that the United States is the better regulator of U.S. issuers would not change, however, even if, for the sake of argument, I were to incorporate public choice theory into the analy-

199. The investor residency approach to statutory reach permits a more limited degree of issuer choice also, and to that extent creates the same problems in terms of the U.S. regime's potential application to foreign issuers. The system recommended by Professor Romano whereby each issuer could choose its disclosure regime regardless of its nationality, who its investors were, or where transactions in its shares occurred - would not lead to the kind of problems discussed in this paragraph of the text. See Romano, supra note 15. 
sis and accept the claim that the U.S. domestic disclosure regime requires too much disclosure for the typical U.S. issuer. Public choice theory suggests that regulatory competition creates its own imperfection: regulators giving special weight to the increasing political pressure from members of the securities industry concerned with the volume of transactions effected in the U.S. market. Thus, to be successful, the argument for issuer choice needs a political theory akin to second best theory in welfare economics. The political theory would need to show that this second imperfection created by regulatory competition is optimal given the assumed imperfection that domestic disclosure standards are currently too high. Unless a proponent of regulatory competition can provide such a theory, there is as much reason to believe these competitioninduced political pressures will represent an overdose, as an appropriate antidote, to the assumed problem of too much disclosure regulation. Moreover, even if the current U.S. regime requires more disclosure than is socially optimal for the typical U.S. issuer and, as globalization proceeds, the regulatory competition from permitting issuers choice did result in just the correct readjustment downward in the U.S. requirements, an approach based on issuer choice will also result in many U.S. issuers choosing some other regime. Given the preferences of the persons making these choices, these issuers will generally choose regimes requiring a lower than socially optimal level of disclosure.

A second argument for permitting issuer choice is that doing so can better accommodate differences among U.S. issuers' socially optimal levels of disclosure. There is no assurance, however, that permitting choice will lead to a set of regimes corresponding to these differing issuer needs. Each of the world's major jurisdictions may, in an effort to appeal to the broadest segment of the market, in the end require approximately the same level of disclosure as all the others. If this happens, the resulting uniform requirements will be ones less suited to the needs of individual U.S. issuers than the current U.S. regime. Even if issuer choice does lead to an appropriately differentiated set of regimes, the preferences of the persons making the issuers' choices again means that there will be a bias for issuers to disclose at a socially suboptimal level. This bias is likely to outweigh the customizing benefits of permitting issuer choice. Finally, assuming that issuer choice is the result of an approach to statutory reach based on transaction location or investor residency, the consequent application of the U.S. regime to foreign issuers will 
reduce the volume of transactions effected in the United States and damage U.S. foreign relations.

\section{CONClusion}

The case is strong for the United States to switch to the issuer nationality approach for determining the reach of the U.S. mandatory disclosure rules. Such a switch assures that the U.S. regime will be applied to all the world's issuers whose disclosure behavior primarily affects U.S. welfare and not to ones whose disclosure behavior primarily affects only the welfare of persons in other countries. A switch to issuer nationality also reduces the risk that political pressures accompanying increasing globalization will succeed in relaxing U.S. standards below the level that maximizes U.S. welfare.

On its face, a proposal not to impose the U.S. regime on foreign issuers whose shares are offered or traded in the United States seems radical, notwithstanding its merits. That does not mean its chances of adoption are poor. The same forces that would tirelessly work to reduce U.S. disclosure standards if the U.S. retains its current approach to statutory reach could easily change course and support the proposal set out here. There are already signs of this in the New York Stock Exchange call to allow exchange trading in the United States of the shares of prominent foreign issuers based on international accounting standards rather than U.S. generally accepted accounting practices. ${ }^{200}$ Applying the issuer nationality approach to secondary trading of these better known issuers would be an opening wedge that would make the approach feel less radical over time and permit analysis of the merits of extending it further.

It is also important to keep time frames in mind. While trends toward globalization of the market for securities make my proposal far more likely to be adopted than might appear to be the case at first glance, a nationally based system of disclosure regulation employing the issuer nationality approach to statutory reach is probably only workable into the medium-term future. Contrary to the assertions of purveyors of what some call "globaloney," little of the world's production today is being undertaken by issuers with no clear national center of gravity. ${ }^{201}$ But the day will come, perhaps a few decades off, when some significant portion will be. At that

200. See supra note 148 .

201. See supra note 40. The European Community can, to the extent necessary, be counted as a "nation" for purposes of this statement since the implications are the same. 
time, the arguments against a uniform international regime to regulate the disclosure of at least this special class of issuers will lose much of their force, particularly if an international institution with greater political legitimacy and expertise than we find today can be developed to promulgate its rules and provide administration. The problem for U.S. policymakers right now, however, is how to fashion a practical approach to statutory reach that meets our needs into the medium-term future. Issuer nationality is the solution. 


\section{APPENDIX I \\ Impact of Globalization of Financial Information on Level of Trading in Two Countries, One With Strict Disclosure Standards and One With Lenient Disclosure STANDARDS}

The model presented below posits two countries, $A$, which has more lenient disclosure standards and a larger pool of investors, and $B$, which has stricter standards and a smaller pool. Thus, $B$ is like the United States, and $A$ like the rest of the world. Each country applies its rules in accordance with the goal of investor protection. Complying with $B$ 's stricter standards implies that $A$ 's standards are met as well. The model is intended to help analyze two issues that arise when the investor residency is the approach to statutory reach adopted by country $B$. First, assuming that $B$ 's standards remain unchanged, what would be the impact of the full global diffusion of financial information on the level of share trading in each country? Second, what would the impact of full global diffusion of information be on issuer sensitivity, i.e., the power of a given reduction in $B$ 's required level of disclosure to increase the level of transactions effected in $B$ ?

The model is structured in terms of two representative issuers, $X$ from $B$ and $Y$ from $A$. If everything that could be publicly known about $X$ and $Y$ were known about them in each country, a share of one would, in each possible future state of nature, be seen as producing a return just equal the return of the other. There are two pools of investors, those from $A$ and those from $B$. Each pool of investors will have a downward sloping demand curve for each security, reflecting the security's variance-covariance characteristics and investors' heterogeneous expectations (as a result, at least in part, from less than full diffusion of information within each pool). Since $A$ 's pool is larger than $B$ 's, the downward slopes of its demand curves are shallower than those of $B$ 's. As long as there is not full global diffusion of financial information - i.e., as long as less is known about an issuer among the pool of investors abroad than among investors in its home pool - the foreign investors impose an ignorance discount in forming their demand for the issuer's shares. $^{202} Q$ is the total number of shares of an issuer that will be

202. This description of the demand function of foreign investors for an issuer's shares corresponds to the fact that investors display a home country bias in their choice of shares and that this bias is generally attributed to differences between the information investors possess concerning home country issuers and the information they possess concerning foreign issuers. See, e.g., Martin Feldstein, Domestic Saving and International Capital Movements in the Long Run and the Short Run, 21 Eur. ECon. Rev. 129, 130-31, 148 n.27 (1983) (finding 
outstanding and it is proportional to the size of the firm. We assume nothing about the distribution of firm sizes in each economy. We do assume for the moment that the extra burden of meeting $B$ 's stricter disclosure standards, $C,{ }^{203}$ is proportional to the firm's size and would be identical if $X$ and $Y$ were the same size, i.e., if $C_{x}$ is the total cost of compliance for $X$ and $C_{y}$ for $Y$, for each issuer, $C_{x}$ (i) would equal $C_{y}$ if the issuers were the same size, and (ii) varies proportionally with $Q$ so that $C_{x} / Q_{x}$ is constant and equals $C_{y} / Q_{y}$ for the other firm.

Neither issuer can have any investors resident in $B$ unless it complies with $B$ 's disclosure requirements. Each can control whether it has any such investors. Each is going to be a public company in any event and so its choice as to whether or not to comply with $B$ 's standards depends on whether the price advantages of having investors in $B$ as well as in $A$ are greater than the costs of compliance with $B$ 's standards.

\section{Definition of Demand Functions}

$A x_{o}(Q)=$ current demand function for shares of $X$ if they were only available to investors in $A$

$B x_{o}(Q)=$ current demand function for shares of $X$ if they were only available to investors in $B$

$A B x_{o}(Q)=$ current demand function for shares of $X$ if they were available to investors in both $A$ and $B$

$A y_{o}(Q)=$ current demand function for shares of $Y$ if they were only available to investors in $A$

$B y_{o}(Q)=$ current demand function for shares of $Y$ if they were only available to investors in $B$

$A B y_{o}(Q)=$ current demand function for shares of $Y$ if they were available to investors in both $A$ and $B$

substantial imperfections in the international capital market and attributing them in part to investors having a higher subjective variance on foreign returns due to less information); Martin Feldstein \& Charles Horioka, Domestic Savings and International Capital Flows, 90 Econ. J. 314. 316, 321 (1980) (finding a high correlation between marginal increases in domestic savings and in domestic investment and attributing these in part to investors' greater uncertainty concerning foreign issuers due to less information); Robert E. Lucas, Jr., Interest Rates and Currency Prices in a Two-Country World, 10 J. MONETARY Econ. 335, 357 (1983) (explaining home bias as the result of the local nature of information but noting the lack of models that even begin to explain the relationship). I discuss this subject in more detail in Fox, Disclosure in a Globalizing Market, supra note 1, at sections I.B.1 and I.D.

203. $C$ is net of any reputational benefit that the issuer receives from complying with the U.S. regime and thus is equivalent to the term "burden" in Parts VI and VII. I assume that for $X$ and $Y$ compliance is, on a net basis, in fact a burden for these issuers. See supra note $152-57$ and accompanying text. 
$A x_{1}(Q)=$ demand function after full global diffusion of information for shares of $X$ if they were only available to investors in $A$ $B x_{I}(Q)=$ demand function after full global diffusion of information for shares of $X$ if they were only available to investors in $B$ $A B x_{1}(Q)=$ demand function after full global diffusion of information for shares of $X$ if they were available to investors in both $A$ and $B$ $A y_{1}(Q)=$ demand function after full global diffusion of information for shares of $Y$ if they were only available to investors in $A$ $B y_{1}(Q)=$ demand function after full global diffusion of information for shares of $Y$ if they were only available to investors in $B$ $A B y_{1}(Q)=$ demand function after full global diffusion of information for shares of $Y$ if they were available to investors in both $A$ and $B$

\section{Demand Curve Assumptions and Specifications}

Note: All the demand curves for Issuer $X$ shares are depicted in Diagram $I-X$ and all the demand curves for Issuer $Y$ shares are depicted in Diagram $I-Y$.

$$
\begin{aligned}
& \text { (i) } A x_{o}(Q)=d-f Q \\
& (Q \geq 0) \\
& B x_{o}(Q)=e-g Q \\
& (Q \geq 0) \\
& A y_{o}(Q)=e-f Q \\
& (Q \geq 0) \\
& B y_{o}(Q)=d-g Q
\end{aligned}
$$

These are standard straight line demand functions where price declines with quantity offered, $e, d, f$, and $g$ being all greater than 0 . $e>d$ and $g>f$ even though in each possible future state of nature shares of $x$ and $y$ will yield identical returns. $e>d$ reflects the fact that currently, with less full global distribution of information, for all $Q$ 's, the foreign country's issuer is discounted by $(e-d) . \mathrm{g}>\mathrm{f}$ reflects the fact that $A$ represents a larger pool of investors than does $B$. Therefore each price would be the reservation price for more investors in $A$ than in $B$ even if evaluations of the issuers were distributed through the two populations in the same proportions. ${ }^{204}$ In the example depicted in Diagrams I-X and I-Y, $e=\$ 10.60, d=$ $\$ 10.50, f=.0025$ and $g=.0050$. Thus the discount is $\$ .10$.

(ii) $B x_{o}(Q)=B x_{1}(Q)$ and $A y_{o}(Q)=A y_{1}(Q)$, i.e., full global diffusion of financial information concerning an issuer does not change the evaluation of, or demand for, the issuer's shares in its home country.

(iii) $A x_{1}(Q)=e-f Q$

$$
B y_{1}(Q)=e-g Q
$$

204. See Choi \& Guzman, Dangerous Extraterritoriality, supra note 9, at 225. 
With full global diffusion of financial information, investors in the country different from the issuer's home country learn what investors in the issuer's country already know about the issuer. Since the issuers' shares have the same prospects, evaluations of the issuers are distributed in the same proportions through the pools of investors in the issuer's home country and the one abroad, but $A$ has a larger pool of investors than $B$ and so the slope of the demand curve is shallower.

$$
\text { Derivation of } A B x_{o}(Q), A B x_{1}(Q), A B y_{o}(Q) \text { and } A B y_{1}(Q)
$$

$\boldsymbol{A B x _ { o }}$

(1) $A x_{o}(Q)=P=d-f Q$

Let $Q x_{o a}=$ Quantity of $X$ shares currently demanded in $A$ at price $P$.

(2) $Q x_{o a}=(1 / f)(d-P)$

$P \leq d$

$=0$

$P>d$

(3) $B x_{o}(Q)=P=e-g Q$

$(Q \geq 0)$

Let $Q x_{o b}=$ Quantity of $X$ shares currently demanded in $B$ at price $P$.

$$
\begin{aligned}
Q x_{o b} & =(1 / g)(e-P) & & P \leq e \\
& =0 & & P>e
\end{aligned}
$$

Let $Q x_{o a b}=Q x_{o a}+Q x_{o b}=$ Quantity of $X$ shares currently demanded at price $P$ in $A$ and $B$ together if they are available to both pools of investors.

$$
\begin{aligned}
\mathrm{Qx}_{\mathrm{oab}} & =Q x_{o b}=(1 / g)(e-P) & d<P \leq e \\
Q x_{\text {oab }} & =(1 / f)(d-P)+(1 / g)(e-P) & P \leq d \\
& =(1 / f g)[(g d+f e)-(g+f) P] &
\end{aligned}
$$

Therefore,

$$
\begin{aligned}
& P=A B x_{o}(Q)=e-g Q \\
& P=A B x_{o}(Q)=(g d+f e) /(g+f)-Q(g f /(g+f)) \\
& 0<\mathrm{Q} \leq(\mathrm{e}-\mathrm{d}) / \mathrm{g} \\
& Q>(e-d) / g
\end{aligned}
$$

In the example depicted in Diagram I-X, $(e-d) / g=20$. If $X$ has fewer than 20 shares outstanding, the demand for them in $B$ alone would put the price above $\$ 10.50$ and hence no shares would be demanded by investors in $A$, who put a discount on shares from $B$ (reflected by $A x_{o}$ starting at $\$ 10.50, \$ .10$ below $B x_{o}$ ). Thus in this range, $A B x_{o}$ tracks $B x_{o}$. If $X$ has more than 20 shares outstanding, the demand for them if they were sold in $B$ alone would put the price below $\$ 10.50$ and hence there would be a demand by residents 
of $A$. Thus in this range, $A B x_{o}$ represents the horizontal aggregation $B x_{o}$ and $A x_{o}$ and has a shallower slope than either one alone.

$\mathbf{A B x}_{1}$

(1) $A x_{1}(Q)=P=e-f Q$

Let $Q x_{1 a}=$ Quantity of $X$ shares that would be demanded in $A$ at price $P$ after full global diffusion of financial information.

$Q x_{1 a}=(1 / f)(e-P)$

$P \leq e$

$=0$

$P>e$

(3) $B x_{1}(Q)=P=e-g Q$

$(Q \geq 0)$

Let $Q x_{1 b}=$ Quantity of $X$ shares demanded in $B$ at price $P$ after full global diffusion of financial information.

$$
\begin{aligned}
& Q x_{1 b} \quad=(1 / g)(e-P) \\
& =0 \\
& P \leq e \\
& P>e
\end{aligned}
$$

Let $Q x_{1 a b}=Q x_{1 a}+Q x_{1 b}=$ Quantity of $X$ shares demanded at price $P$ in $A$ and $B$ together after full global diffusion of financial information if they are available to both pools of investors.

$$
\begin{array}{rlrl}
Q x_{\text {lab }} & & (1 / f)(e-P)+(1 / g)(e-P) & P \leq e \\
& =[(f+g) / f g][e-P] &
\end{array}
$$

Therefore,

$$
P=A B x_{1}(Q)=e-Q[g f /(f+g)]
$$

In the example depicted in Diagram I-X, after full diffusion, investors in $A$ no longer put a discount on shares from $B$ and so $A x_{1}$ starts at $\$ 10.60$ just as $B x_{1}$ does. Thus, whatever number of shares $X$ has outstanding, $A B x_{1}$ represents the horizontal aggregation $B x_{1}$ and $A x_{1}$, and, over the full range of $Q$, it has a shallower slope than either one alone.

$\mathbf{A B y}_{\text {。 }}$

(1) $A y_{o}(Q)=P=e-f Q$

Let $Q y_{o a}=$ Quantity of $Y$ shares currently demanded in $A$ at price $P$.

(2) $Q y_{o a}=(1 / f)(e-P)$

$$
P \leq e
$$$$
=0
$$

(3) $B y_{o}(Q)=P=d-g Q$

Let $Q y_{o b}=$ Quantity of $Y$ shares currently demanded in $B$ at price $P$. 


$$
\begin{aligned}
& Q y_{o b} \quad=(1 / g)(d-P) \\
& =0 \\
& P \leq d \\
& P>d
\end{aligned}
$$

Let $Q y_{o a b}=Q y_{o a}+Q y_{o b}=$ Quantity of $Y$ shares currently demanded at price $P$ in $A$ and $B$ together if they are available to both pools of investors.

$$
\begin{aligned}
& Q y_{o a b} \quad=Q y_{o a}=(1 / f)(e-P) \\
& d<P \leq e \\
& Q y_{\text {oab }} \quad=(1 / f)(e-P)+(1 / g)(d-P) \\
& =(1 / f g)[(g e+f d)-(g+f) P] \\
& P \leq d
\end{aligned}
$$

Therefore,

$$
\begin{array}{lr}
P=A B y_{o}(Q)=e-f Q & 0<Q \leq(e-d) / f \\
P=A B y_{o}(Q)=(g e+f d) /(g+f)-(f g /(g+f)) Q & Q>(e-d) / f
\end{array}
$$

In the example depicted in Diagram I-Y, $(e-d) / f=40$. If $Y$ has fewer than 40 shares outstanding, the demand for them in $A$ alone would put the price above $\$ 10.50$ and hence no shares would be demanded by investors in $B$, who put a discount on shares from $A$ (reflected by $B y_{o}$ starting at $\$ 10.50, \$ .10$ below $A y_{o}$ ). Thus in this range, $A B y_{o}$ tracks $A y_{o}$. If $X$ has more than 40 shares outstanding, the demand for them if they were sold in $A$ alone would put the price below $\$ 10.50$ and hence there would be a demand for them by residents of $B$ if they are available there as well. Thus in this range, $A B y_{o}$ represents the horizontal aggregation $B y_{o}$ and $A y_{o}$ and has a shallower slope than either one alone.

$\mathbf{A B y _ { 1 }}$

(1) $A y_{l}(Q)=P=e-f Q(Q \geq 0)$

Let $Q y_{1 a}=$ Quantity of $Y$ shares that would be demanded in $A$ at price $P$ after full global diffusion of financial information.

$$
\begin{aligned}
& Q y_{1 a}=(1 / f)(e-P) \\
& =0 \\
& P \leq e \\
& P>e \\
& \text { (3) } B y_{I}(Q)=P=e-g Q
\end{aligned}
$$

Let $Q y_{1 b}=$ Quantity of $Y$ shares demanded in $B$ at price $P$ after full global diffusion of financial information.

$$
\begin{aligned}
Q y_{1 b} & =(1 / g)(e-P) & & P \leq e \\
& =0 & & P>e
\end{aligned}
$$

Let $Q y_{1 a b}=Q y_{1 a}+Q y_{1 b}=$ Quantity of $Y$ shares demanded at price $P$ in $A$ and $B$ together after full global diffusion of financial information if they are available to both pools of investors.

$$
Q y_{1 a b}=(1 / f)(e-P)+(1 / g)(e-P) \quad P \leq e
$$




$$
=[(f+g) / f g][e-P]
$$

Therefore,

$$
P=A B y_{1}(Q)=e-Q[g f /(f+g)]
$$

In the example depicted in Diagram I-Y, after full diffusion, investors in $B$ no longer put a discount on shares from $A$ and so $B y_{1}$ starts at $\$ 10.60$ just as $A y_{1}$ does. Thus, whatever number of shares $Y$ has outstanding, $A B y_{1}$ represents the horizontal aggregation $B y_{1}$ and $A y_{1}$, and, over the full range of $Q$, it has a shallower slope than either one alone.

A. Proof that if regulation remains unchanged, full global diffusion of financial information will reduce the number of $B$ 's issuers that choose to comply with $B$ 's disclosure requirements.

If regulations in both $B$ and $A$ remain unchanged after full global diffusion of financial information, then, for any given number, $Q$, of shares that $X$, the representative $B$ issuer, will have outstanding, the per share extra cost of complying with $B$ 's stricter regime, $C(Q) / Q$, will be unchanged. Before full diffusion, $X$ will comply with $B$ 's disclosure requirements if $A B x_{o}(Q)-A x_{o}(Q)>$ $C(Q) / Q$, i.e., if the cost of compliance, which permits access to investors in $B$, is less than the price damage from relying solely on in investors in $A$. Similarly, after full diffusion, $X$ will comply if $A B x_{1}(Q)-A x_{l}(Q)>C(Q) / Q$. For any given $Q$, full diffusion reduces the gain from complying, and hence, at constant cost, the likelihood that the issuer chooses to do so if $\left[A B x_{o}(Q)-A x_{o}(Q)\right]-$ $\left[A B x_{I}(Q)-A x_{I}(Q)\right]>0$, i.e., if the price damage from relying only on investors in $A$ goes down. As shown below, this is so for all values of $Q$.

$$
\begin{aligned}
& \mathbf{Q} \leq(\mathbf{e}-\mathbf{d}) / \mathbf{g} \\
& {\left[A B x_{o}(Q)-A x_{o}(Q)\right]-\left[A B x_{1}(Q)-A x_{1}(Q)\right]=} \\
& {[(e-g Q)-(d-f Q)]-[(e-(g f /(f+g)) Q-(e-f Q)]=} \\
& (e-d)-(g-g f /(f+g)) Q= \\
& (e-d)-Q g(1-f /(f+g))
\end{aligned}
$$

Thus, in this range of $Q$, the reduction in the gain from compliance, is a declining function of $Q$. It is positive at $Q=0$ since $e>d$. If it is also positive at the end point of this range of $Q$, i.e., at $Q=(e-$ $d) / g$, it is positive throughout the range. At $Q=(e-d) / g$, its value is

$$
\begin{aligned}
& (e-d)-[(e-d) / g][g(1-f /(f+g))] \\
& (e-d)[1-(1-f /(f+g))]=
\end{aligned}
$$




$$
(e-d)[f /(f+g)]>0
$$

since $f>0, g>0$ and $e>d$. Thus, in this range of $Q$, diffusion will result in a reduction of the value of compliance.

$$
\begin{aligned}
& \mathbf{Q}>(\mathbf{e}-\mathbf{d}) / \mathbf{g} \\
& {\left[A B x_{o}(Q)-A x_{o}(Q]\right]-\left[A B x_{1}(Q)-A x_{1}(Q)\right]=} \\
& {[(f e+g d) /(f+g)-Q(g f /(f+g))-(d-f Q)]-} \\
& {[(e-Q(g f /(f+g))-(e-f Q)]=} \\
& \quad(f e+g d) /(f+g)-d= \\
& (f e+g d) /(f+g)-d(f+g) /(f+g)= \\
& \quad(f e-f d) /(f+g)>0 \\
& \text { since } e>d>0, f>0, \text { and } g>0 .
\end{aligned}
$$

Thus full global diffusion of knowledge will result in a reduction in the benefit from compliance for all values of $Q$. With the burden of compliance constant, fewer $B$ issuers will comply with $B$ 's stricter disclosure requirements. This can again be seen in the example depicted in Diagram I-X, where $(e-d) / g=20$. First consider the situation if $X$ has 20 or fewer shares outstanding. The pre-diffusion price damage from relying on investors from $A$ alone (the difference between $A x_{o}$ and $A B x_{o}$ ) starts at $\$ .10$ and declines up to the point that $X$ has 20 shares outstanding. There, the price damage is $\$ .05$. The after-diffusion price damage from relying on investors from $A$ alone (the difference between $A x_{1}$ and $A B x_{1}$ ) starts at 0 and increases in proportion to the number of shares $X$ has outstanding so that at the point that $X$ has 20 shares outstanding the price damage is .0166 . Thus over this whole range, the post-diffusion price damage from relying solely on investors from $A$ is less than the prediffusion price damage, starting at a difference of $\$ .05$ and ending at a difference of $\$ .033$. The difference in price damage before and after diffusion remains at $\$ .033$ for any number of $X$ shares outstanding in excess of 20 . Thus, whatever the burden of compliance, there is a smaller range of issuers from $B$ that will find it worthwhile after diffusion than before.

B. Proof that if regulation remains unchanged, full global diffusion of financial information will increase the number of $A$ 's issuers that choose to comply with $B$ 's disclosure requirements.

If regulations in both $B$ and $A$ remain unchanged after full global diffusion of financial information, then, for any given number, $Q$, of shares that $Y$, the representative $A$ issuer, will have outstanding, the per share extra cost of complying with $B$ 's stricter regime, $C(Q) / Q$, will be unchanged. Before full diffusion, $Y$ will 
comply with $B$ 's disclosure requirements if $A B y_{o}(Q)-A y_{o}(Q)>$ $C(Q) / Q$, i.e. if the cost of compliance, which permits access to investors in $B$, is less than the price damage from relying solely on investors in $A$. Similarly, after full diffusion, $Y$ will comply if $A B y_{1}(Q)-A y_{1}(Q)>C(Q) / Q$. For any given $Q$, full diffusion increases the gain from complying, and hence, at constant cost, the likelihood that the issuer chooses to do so if $\left[A B y_{o}(Q)-A y_{o}(Q)\right]-$ $\left[A B y_{1}(Q)-A y_{1}(Q)\right]<0$. As shown below, this is so for all values of Q.

$\mathbf{Q} \leq(\mathbf{e}-\mathbf{d}) / \mathbf{f}$

$$
\begin{aligned}
& {\left[A B y_{o}(Q)-A y_{o}(Q)\right]-\left[A B y_{1}(Q)-A y_{1}(Q)\right]=} \\
& A B y_{o}(Q)-A B y_{1}(Q)= \\
& {[e-f Q]-[e-Q(g f /(g+f))]=} \\
& Q f[(g /(g+f))-1]<0
\end{aligned}
$$

since $\mathrm{f}>0$ and $\mathrm{g}>0$ and so $[(\mathrm{g} /(\mathrm{g}+\mathrm{f}))-1]<0$.

Thus, in this range of $Q$, global diffusion results in an increase in the gain from compliance, which increase is a positive function of $Q$.

$$
\mathbf{Q}>(\mathbf{e}-\mathbf{d}) / \mathbf{f}
$$

$$
\begin{aligned}
& {\left[A B y_{o}(Q)-A y_{o}(Q)\right]-\left[A B y_{1}(Q)-A y_{1}(Q)\right]=} \\
& A B y_{o}(Q)-A B y_{1}(Q)= \\
& {[(g e+f d) /(f+g)-Q(g f /(f+g))]-[e-Q(g f /(f+g))]=} \\
& (g e+f d) /(f+g)-e= \\
& (g e+f d) /(f+g)-e(f+g) /(f+g)= \\
& (f d-f e) /(f+g)<0
\end{aligned}
$$

since $\mathrm{e}>\mathrm{d}>0, \mathrm{f}>0$, and $\mathrm{g}>0$.

Thus, for all values of $Q$, global diffusion results in an increase in the gain from compliance. With the burden of compliance constant, more $A$ issuers will comply with $B$ 's requirements. This can again be seen in the example depicted in Diagram I-Y, where $(e-$ $d) / f=40$. First consider the situation if $Y$ has 40 or fewer shares outstanding. The pre-diffusion price damage from relying on investors from $A$ alone (the difference between $A y_{o}$ and $A B y_{o}$ ) is 0 . The after-diffusion price damage from relying on investors from $A$ alone (the difference between $A y_{1}$ and $A B y_{1}$ ) starts at 0 and increases in proportion to the number of shares $Y$ has outstanding so that at the point that $Y$ has 40 shares outstanding the price damage is $\$ .033$. Thus over this whole range, the post-diffusion price damage from relying solely on investors from $A$ is greater than the pre-diffusion price damage, growing from a difference of 0 to a difference of $\$ .033$. The difference in price damage before and after diffusion 
remains at $\$ .033$ for any number of $Y$ shares outstanding in excess of 40 . Thus, whatever the burden of compliance, there is a larger range of issuers from $A$ that will find it worthwhile after diffusion than before.

C. For smaller $B$ issuers, the decrease in the gain from compliance after full global diffusion of financial information will exceed the increase in gain for comparable smaller $A$ issuers. For comparable larger $B$ and $A$ issuers, the respective decrease and increase will be identical in size. With regulation unchanged, diffusion's effect, however, on the aggregate number of issuers registered and trading volume in $B$ is indeterminate.

Full global diffusion of financial information will result in a larger reduction in the gain from compliance with $B$ 's disclosure regulations by a $B$ issuer with a given $Q$ than an increase in the gain from such compliance by a comparable $A$ issuer if the "gain change difference expression" set out below is positive, i.e., if

$$
\begin{aligned}
& {\left[\left(A B x_{o}(Q)-A x_{o}(Q)\right)-\left(A B x_{1}(Q)-A x_{1}(Q)\right)\right]+\left[\left(A B y_{o}(Q)-\right.\right.} \\
& \left.\left.\quad A y_{o}(Q)\right)-\left(A B y_{1}(Q)-A y_{1}(Q)\right)\right]= \\
& {\left[\left(A B x_{o}(Q)-A x_{o}(Q)\right)-\left(A B x_{1}(Q)-A x_{1}(Q)\right]+\left[A B y_{1}(Q)-\right.\right.} \\
& \left.A B y_{o}(Q)\right]>0 .
\end{aligned}
$$

For $\mathbf{0}<\mathbf{Q} \leq(\mathbf{e}-\mathbf{d}) / \mathbf{g}$, the gain change difference expression equals:

$$
(e-d)-g(1-(f /(f+g)) Q-f(1-(g /(g+f)) Q
$$

This starts positive when $Q=0$ since $e>d$. At $Q=(e-d) / g$, the expression then equals

$$
\begin{aligned}
& (e-d)-[\mathrm{g}(1-(f /(f+g))](e-d) / g-[f(1-(g /(g+f))](e-d) / \\
& g= \\
& (e-d)-[(1-(f /(f+g))](e-d)-[f(f /(g+f))](e-d) / g= \\
& (e-d)[1-1+(f /(f+g)-(f / g)(f /(f+g))]= \\
& (e-d)(f /(f+g))(1-f / g)>0
\end{aligned}
$$

since $e>d>0$ and $g>f>0$. Thus, over this range of $Q$, the full diffusion's decrease in gain from compliance with $B$ 's disclosure regulations by $B$ issuers exceeds its increase in the gain from compliance by $A$ issuers.

For $(\mathbf{e}-\mathbf{d}) / \mathbf{g} \leq \mathbf{Q} \leq(\mathbf{e}-\mathbf{d}) / \mathbf{f}$, the gain change difference expression equals:

$$
\begin{aligned}
& f(e-d) /(f+g)-(f(1-(g /(g+f))) Q= \\
& (f /(f+g))(e-d)-(f l(f+g)) f Q= \\
& (f /(f+g))[(e-d)-f Q]
\end{aligned}
$$


When $Q=(e-d) / g$, the value of the expression above is

$$
\begin{aligned}
& (f /(f+g))[(e-d)-f(e-d) / g]= \\
& (f /(f+g))(e-d)(1-f / g)
\end{aligned}
$$

and is thus the same as when $Q<(e-d) / g$ and, as shown in the preceding paragraph, is positive.

When $Q=(e-d) / f$, the value of the expression above equals

$$
\begin{aligned}
& (f /(f+g))[(e-d)-f(e-d) / f]= \\
& (f /(f+g))[(e-d)-(e-d)]=0
\end{aligned}
$$

Since, over this range of $Q$, the value of the expression is a linear declining function of $Q$ that is positive at the beginning point and 0 at the end point, the decrease in gain from compliance with $B$ 's disclosure regulations by $B$ issuers with full diffusion exceeds the increase in the gain from compliance by $A$ issuers with full diffusion up until the point that $Q$ reaches $(e-d) / f$.

For $\mathbf{Q}>(\mathbf{e}-\mathbf{d}) / \mathbf{f}$, the gain change difference expression equals:

$$
(f e-f d) /(f+g)-(f e-f d) /(f+g)=0
$$

So, over the rest of the range of $Q$, the value of the expression is 0 , and thus full diffusion's decrease in gain for $B$ issuers from compliance with $B$ 's disclosure regulations just equals its increase in the gain for $A$ issuers from compliance.

We have proved that for smaller $B$ issuers, the decrease in the gain from compliance after full global diffusion of financial information will exceed the increase in gain for comparable smaller $A$ issuers and that for larger issuers there is no difference. However, with regulation unchanged, full diffusion's impact on the number of transactions effected in $B$ is still indeterminate since we have made no assumption about the distribution of issuers by size in each country. This is true even if the burden of compliance per share were the same for all issuers in $A$ and $B$ and the distribution of issuers by size were the same for both countries. The $B$ issuers that complied before diffusion and not after will each have fewer shares outstanding than the $A$ issuers that did not comply before and do after. The reduction in the number of $B$ issuers may (or may not) be greater than the increase in $A$ issuers, but even if it is, it may not be great enough to make up for the difference in the size of the issuers. 
D. Demonstration that the sensitivity of issuers to changes in $B$ 's required level of disclosure increases with full global diffusion of financial information.

As will be shown below, the sensitivity of the number of issuers complying with $B$ 's regime to changes in the burden of compliance is connected to the relationship between $Q$ and the price gain from compliance.

\section{a. Relationship between $Q$ and the price gain from compliance.}

For issuers under the circumstances indicated below and in the ranges of $Q$ indicated, the price gain from compliance increases with $Q$.

Before diffusion, B issuers with $\mathbf{Q}>(\mathbf{e}-\mathbf{d}) / \mathbf{g} . G x_{o}$ is the price gain from compliance.

$$
\begin{array}{lr}
G x_{o}(Q)=A B x_{o}(Q)-A x_{o}(Q) & \\
=[(f e+g d) /(f+g)-Q(g f /(f+g))]-[d-f Q] & Q>(e-d) / g \\
d G x_{o} / d Q=f[1-(g /(g+f))]>0 & Q>(e-d) / g \\
\text { since } g>0 \text { and } f>0 \text { and so }(g /(g+f))<1 &
\end{array}
$$

Before diffusion, $\mathbf{A}$ issuers with $\mathbf{Q}>(\mathbf{e}-\mathbf{d}) / \mathbf{f} . G y_{o}$ is the price gain from compliance with $B$ 's disclosure requirements.

$$
\begin{array}{ll}
G y_{o}(Q)=A B y_{o}(Q)-A y_{o}(Q) & \\
\quad=[(g e+f d) /(g+f)-(f g /(g+f)) Q]-[e-f Q] & Q>(e-d) / f \\
\quad=[(g e+f d) /(g+f)-e]-[f(g /(g+f))-f] Q & \\
d G y_{o} / d Q=f[1-(g /(g+f))]>0 & Q>(e-d) / f
\end{array}
$$

After diffusion, all $\mathbf{B}$ issuers. $G x_{I}$ is the price gain from compliance with $B$ 's disclosure requirements.

$$
\begin{aligned}
& G x_{1}(Q)=A B x_{1}(Q)-A x_{1}(Q) \\
& \quad=[(e-(g f /(f+g)) Q]-[e-f Q] \\
& d G x_{1} / d Q=f[1-(g /(g+f))]>0
\end{aligned}
$$

After diffusion, all $\mathbf{A}$ issuers. $G y_{1}$ is the price gain from compliance.

$$
\begin{aligned}
& G y_{1}(Q)=A B y_{1}(Q)-A y_{1}(Q) \\
& \quad=[(e-(g f /(f+g)) Q]-[e-f Q] \\
& d G y_{1} / d Q=f[1-(g /(g+f))]>0
\end{aligned}
$$

As for the remaining possible cases, the price gain from compliance is either inversely related, or unrelated, to $Q$.

Before diffusion, $B$ issuers with $\mathbf{Q} \leq(\mathbf{e}-\mathbf{d}) / \mathrm{g}$.

$$
\begin{array}{ll}
G x_{o}(Q)=A B x_{o}(Q)-A x_{o}(Q) & \\
\quad=[e-g Q]-[d-f Q] & Q \leq(e-d) / g
\end{array}
$$




$$
d G x_{o} / d Q=(f-g)<0
$$$$
Q \leq(e-d) / g
$$

since $g>f>0$. $G x_{o}$, however, is positive throughout this range. At $Q=0, G x_{o}=(e-d)>0$. At $Q=(e-d) / g$

$$
\begin{aligned}
& G x_{o}(Q)=(e-d)-(g-f)[(e-d) / g] \\
& =(e-d)[1-((g-f) / g)]>0
\end{aligned}
$$

since $g>f>0$ and $(g-f) / g<1$.

Before diffusion, $\mathbf{A}$ issuers with $\mathbf{Q} \leq(\mathrm{e}-\mathrm{d}) / \mathrm{f}$.

$$
\begin{gathered}
G y_{o}(Q)=A B y_{o}(Q)-A y_{o}(Q) \\
\quad=(e-f Q)-(e-f Q)=0
\end{gathered}
$$

$$
Q \leq(e-d) / f
$$

Thus, for $Y$ issuers in this range, there is no price gain from compliance.

b. Sensitivity of the extent of compliance to the lowering of the cost of compliance.

Set $C$ equal to an issuer's extra burden in complying with $B$ 's disclosure regulations and $c=C / Q$, the extra burden of compliance on a per share basis. The question that we want to investigate is the difference between how, before full global diffusion of financial information, a lowering of $C$ affects the range of issuers that would choose to comply with $B$ 's disclosure requirements, and how, after such diffusion, a lowering of $C$ would affect this range. I will assume in the text that $C$ is proportional to $Q$, i.e., that for any given level of required disclosure, an issuer's $c$ will be constant over the full range of $Q$, and conclude that diffusion will increase the sensitivity of issuers to a lowering of the burden of compliance. In the margin, I will show that the propositions necessary to reach this conclusion hold as well with the assumption that $C$ is constant over the full range of $Q$. Since reality is probably somewhere in between, with larger issuers having larger compliance burdens than smaller ones but not proportionately larger ones, the conclusion should hold in the real world as well.

Before diffusion, $\mathbf{B}$ issuers. Before diffusion, the size of the price gain to $B$ issuers from complying with $B$ 's disclosure regulations starts, when $Q=0$, at $(e-d)$. It declines to $(e-d)(f /(f+g))$, at $Q=(e-d) / g$. From that point on, it increases as $Q$ increases. Thus, before diffusion, any $B$ issuer that wanted to be publicly traded would, regardless of its $Q$, want to comply with $B$ 's disclosure requirements assuming that $c$ was less than $(e-d)(f /(f+g))$, the minimum price gain. Empirically, this would appear to be the case today with the United States as country $B$, since essentially all public U.S. issuers comply with the U.S. requirements, i.e., practi- 
cally none are public only abroad. Thus, before diffusion, a lowering of compliance burdens (and hence each issuer's $c$ ) has no effect on the number of $B$ issuers complying and hence no effect on the number of $B$ issuer share transactions effected in $B .{ }^{205}$

After diffusion, $B$ issuers. After diffusion, the size of the price gain to $X$ from complying with $B$ 's disclosure requirements is 0 at $Q$ $=0$ and increases linearly with $Q$. Thus, for any given $c$ that an issuer may have, there is some minimum $Q_{m}$ at which the price gain is sufficiently large to make compliance worthwhile. $Q_{m}$ can be determined by solving the following equation:

$$
\begin{aligned}
& e-[g f /(f+g)] Q_{m}-c=e-f Q_{m} \\
& Q_{m}=[(f+g) / f f] c \\
& d Q_{m} / d c=(f+g) / f f>0
\end{aligned}
$$

Diffusion, with the burdens of compliance unchanged, will result in $B$ issuers with $Q$ 's less than their $Q_{m}$ 's not complying with $B$ 's disclosure requirements. A lowering of the burdens of compliance lowers $c$ and hence $Q_{m}$, and will increase the number of $B$ issuers complying and hence the number of $B$ issuer share transactions effected in $B .206$

Before diffusion, $\mathbf{A}$ issuers. Before diffusion, the size of the price gain to $Y$ issuers, from complying with $B$ 's disclosure regulations starts, when $Q=0$, at 0 . It remains at 0 up to the point where $Q=(e-d) / f$, and, from that point on, increases as $Q$ increases.

205. If $\mathrm{C}$ were constant, this proposition would be true as long as (i) the value of $\mathrm{C} / \mathrm{Q}$ at $\mathrm{Q}=(\mathrm{e}-\mathrm{d}) / \mathrm{g}$ (the point of minimum per share price gain and the point beyond which the gain increases while $c$ decreases $)$ is less than that minimum price gain, i.e., $(e-d)(f /(f+g))$, and (ii) there are no public issuers with $Q$ 's so small that they are less than $\left[(d-e)+\left((e-d)^{2}-4(f\right.\right.$ $\left.-\mathrm{g})(\mathrm{C}))^{1 / 2}\right] / 2(\mathrm{f}-\mathrm{g})$. The second condition involves the level of $Q$ below which $c$, which equals $C / Q$ and hence is inversely related to $Q$, climbs to the point that exceeds the gain. At this point, the per share price gain equals $c$, i.e.

$$
\begin{aligned}
& (e-d)-(g-f) Q=C / Q \\
& (f-g) Q^{2}+(e-d) Q-C=0
\end{aligned}
$$

an equation that can be solved for $Q$ using the quadratic formula. Again. if the assumption of constant $C$ is correct, these conditions appear to be currently met with the United States as country $B$ since essentially all public U.S. issuers comply with the U.S. requirements. Effectively this is saying that for any U.S. firm so small that its burden of compliance with U.S. disclosure laws outweighs its price gain from going public at home, it is too unknown abroad for that to be an alternative.

206. The same is true if, at any given level of disclosure requirements, $C$ remains constant with changes in $Q$. Any $B$ issuer with a $Q$ greater than a minimum $Q_{m}$ will find compliance worthwhile since the per share price gain will start at 0 and be increasing with $Q$ and the per share cost of compliance will be decreasing with $Q . Q m$ can be determined as follows.

$\left.e-[g f /(f+g)] Q m-C / Q m=e-f Q_{m}\right]$

$Q_{m}^{2}=[(f+g) / f f] C$

$Q_{m}=[(f+g) / f f]^{1 / 2} C^{t / 2}$

$d Q_{n} / d C=\left({ }^{1} h\right)[(f+g) / f f]^{l / 2} C^{l / 2}>0$ 
Thus, for any given $c$, there is some minimum $Q_{m}$, greater than $Q=$ $(e-d) / f$, at which the price gain is sufficiently large to make compliance worthwhile. $Q_{m}$ can be determined by solving the following equation:

$$
\begin{aligned}
& \left.(g e+f d) /(g+f)-[f g /(f+g)] Q_{m}-c=e-f Q_{m}\right] \\
& Q_{m}=(e-d) / f+[(f+g) / f f] c . \\
& d Q_{m} / d c=(f+g) / f f
\end{aligned}
$$

Thus, even before diffusion, a lowering of $c$ lowers $Q_{m}$ and will increase the number of $A$ issuers complying with $B$ 's disclosure regulations and hence the number of $A$ issuer share transactions effected in B. $^{207}$

After diffusion, $\mathbf{A}$ issuers. After diffusion, the size of the price gain to $Y$ from complying with $B$ 's disclosure requirements is 0 at $Q$ $=0$ and increases linearly with $Q$. Thus, for any given $c$, there is again some minimum $Q=Q_{m}>0$ at which the price gain is sufficiently large to make compliance worthwhile. $Q_{m}$ can be determined by solving the following equation:

$$
\begin{aligned}
& e-[g f /(f+g)] Q_{m}-c=e-f Q_{m} \\
& Q_{m}=[(f+g) / f f] c \\
& d Q_{m} / d c=(f+g) / f f>0
\end{aligned}
$$

Diffusion, with $c$ unchanged, will lower $Q_{m}$ by $(e-d) / f$. This will increase the number of $A$ issuers complying with $B$ 's disclosure regulations and hence the number of $A$ issuer share transactions effected in $B$. A lowering of disclosure requirements and hence of $c$ would further lower $Q_{m}$ and would further increase the number of $A$ issuers complying and hence the number of $A$ issuer share transactions effected in $B .^{208}$

Aggregate impact of diffusion on sensitivity. Before diffusion, all publicly traded $B$ issuers will comply with $B$ 's more onerous dis-

207. The same is true if, for an given level of required disclosure, $C$ is constant across $Q$. Again there would be a $Q_{m}$ that can be determined as follows.

$$
\begin{aligned}
& (g e+f d) /(g+f)-[f g /(f+g)] Q_{m}-C / Q_{m}=e-f Q_{m} \\
& Q_{m}=(e-d) / f+[(f+g) / f f]\left(C / Q_{m}\right) . \\
& Q_{m}{ }^{2}=[(e-d) / f] Q_{m}+[(f+g) / f f] C=0 \\
& Q_{m}{ }^{2}-[(e-d) / f] Q m-[(f+g) / f f] C=0
\end{aligned}
$$

Using the quadratic formula,

$$
\begin{aligned}
& Q_{m}=(1 / 2)[(e-d) / f]+(1 / 2)\left[((e-d) / f)^{2}+4((f+g) / f f) C\right]^{1 / 2} \\
& d Q_{m} / d C=(1 / 2)(1 / 2)\left[((e-d) / f)^{2}+4((f+g) / f f) C\right]^{-1 / 2}(4)((\mathrm{f}+\mathrm{g}) / \mathrm{ff}) \\
& d Q_{m} / d C=\left[((e-d) / f)^{2}+4((f+g) / f f) C\right]^{-1 / 2}((f+g) / f f)>0
\end{aligned}
$$

208. The same is true if, at any given level of disclosure requirements, $C$ remains constant with changes in $Q$. The analysis is the same as where $C$ remains constant after diffusion in the case of B issuers, see supra note 206. 
closure requirements (assuming, as would appear to be the case with the United States as country $B$, that each $B$ issuer's $c<(e-$ d) $(f /(f+g)))$. Thus $Q_{m}$ for all $B$ issuers is effectively 0 . Lowering the cost of compliance cannot increase the number of $B$ issuers complying and hence the number of $B$ issuer share transactions effected in $B$ because none are sold and traded exclusively abroad now. On the other hand, before diffusion, $A$ issuers will have positive $Q_{m}$ 's. Only some - those with $Q$ 's greater than $Q_{m}-$ will comply. The rest - those with $Q$ 's less than their $Q_{m}$ will not comply. Lowering the burden of compliance would lower the $Q_{m}$ for some issuers to a level below their $Q$ 's and thus induce them to comply. This would increase the number of $A$ issuer share transactions effected in $B$.

Diffusion will result in $B$ issuers having positive, rather than 0 , $Q_{m}$. Thus after diffusion, with no change in the cost of compliance, many $B$ issuers wishing to be publicly traded - those with $Q$ 's lower than $Q_{m}$ - would choose not to comply. As with $A$ issuers even before diffusion, lowering the burden compliance would lower $Q_{m}$, in some cases to a level below their $Q$ 's thereby inducing some $B$ issuers to comply after all and increasing the number of transactions effected in $B$. Diffusion will result in $A$ issuers continuing to have a positive, but lower, $Q_{m}$. With no change in the cost of compliance, the number of $A$ issuers complying with $B$ 's requirements will increase. A lowering of the cost will increase the number more. In aggregate, before diffusion, lowering the burden of compliance will attract additional members of one group $-A$ issuers - to comply. After diffusion, a burden lowering will attract additional members of two groups $-A$ issuers and $B$ issuers - to comply. The post-diffusion potential for attracting additional $B$ issuers means that lowering the burden of compliance will have a larger positive impact on the number of transactions effected in $B$ than before, since there is no reason to believe that the additional $A$ issuer share transactions induced by a given cost lowering would be less after diffusion than before. The marginal impact of the lowering on $Q_{m}$ will for $A$ issuers be the same before and after diffusion, i.e., for $A$ issuers $d Q_{m} / d c$ equals $(f+g) / f f$ both before and after diffusion. While the $A$ issuers attracted by a post-diffusion lowering would be smaller, they would probably be more numerous. 


\section{ApPendix II}

\section{Prisoner's Dilemma Model of Disclosure \\ STANDARds Race to THE BotTOM}

Imagine two identical countries, $A$ and $B$.

\section{INITIAL CONDITIONS}

Initially no transnational securities transactions are possible. Each country chooses the level of disclosure that is substantively optimal, i.e., the marginal social cost just equals the marginal social benefit in terms of improved allocation of capital and agency cost reduction. In each, there is one manufacturing industry, widgets $(W)$, which produces 100 units (W's) per year and one service industry, securities exchange services, which produces 10 units (SE's) per year. In terms of pricing, $1 W=1 S E$. The economy is competitive and the production functions for $W$ and $S E$ meet the ordinary assumptions of concavity and constant returns to scale. The inputs for producing widgets are labor $(L)$ and capital $(K)$. The inputs for producing securities exchange services are labor and brokers $(\mathrm{Br})$. $L, K$, and $B r$ and entrepreneurism are supplied locally. Because the countries are identical, each factor initially earns the same return in both countries.

\section{Transnational Securities Transactions Become Possible: A Lowers Its Level of ReQuired Disclosure AND B Does Not}

It is now possible to effect transactions in one country in the shares of an issuer of the other country and to have shareholders in one country of an issuer of the other. As demonstrated above, ${ }^{209}$ if the countries adhere to a mix of investor and market protection, the lowering by one of its required disclosure level can increase the volume of transactions effected within its borders and the more globalization proceeds, the greater is this gain in volume. Suppose $A$ lowers its level, and $B$ does not.

\section{A. Effects in A}

1. Reduced efficiency in manufacturing. The lowering of the required level of disclosure reduces it below what is substantively optimal. As a result, the manufacturing sector is not as efficient

209. See supra Part IV. 
and so the same level of input would produce less output. Use as an example, a decline of $4 W$. Assume that capital, which is now supplied globally, earns a global rate of return that is essentially the same as its expected return in each country before the requirements were lowered (i.e., it is insignificantly affected by the decline in efficiency) so that the impact of the loss in efficiency is absorbed entirely by entrepreneurs and labor in $A .{ }^{210}$

2. Increased demand for stock exchange services. Issuers in $B$ take steps to facilitate the effecting of transactions in their shares in $A$ and so demand for $A$ 's stock exchange services increases. $L$ is moved out of widgets and into securities exchange services to increase production of these services. Purchasers of this increased production are residents of $B$. Use as an example, a movement of labor sufficient to reduce $W$ by another 9 (so that total $W$ production $=87.5^{211}$ ) and to increase $S E$ by 8 (so that the total $S E$ production $=18)$. The greater reduction in $W$ than increase in $S E$ reflects the fixed supply of $\mathrm{Br}$ and the declining marginal productivity of labor in securities exchange services (the $S E$ mppl being initially equal to the $W \mathrm{mppl}$ ).

3. Increased price for $S E$ and rents for $B r$. The supply of $B r$ is fixed and so the increased demand for $S E$ produced in $A$ will raise the price and raise the return on $B r$. Use as an example a doubling of the price of $S E$ in terms of $W$ so that one $S E$ is now priced at two $W$.

4. A's welfare increases. As long as the increased rents are greater than the loss in efficiency in manufacturing, the lowering of disclosure requirements has increased $A$ 's welfare. In the example, total production is $87.5 \mathrm{~W}$ and $18 S E$. $9 S E$ will be exported in return for $18 \mathrm{~W}$. Thus the suppliers of $L, B r$, and entrepreneurship are now able to consume $105.5 W$ (i.e., $87.5 W+18 W$ ) plus $9 S E$ less payments to capital, compared with $100 \mathrm{~W}$ plus $10 S E$ less somewhat larger payments to capital (reflecting the initially somewhat larger widget industry) before the lowering of requirements. Suppliers of $K$ resi-

210. To illustrate reasonably simply the problem's game theory aspects, it is being modeled as a two-country example. With just two countries of equal size, a significant decline in the efficiency of the manufacturing sector of one would have a palpable effect on the returns to the two nation global pool of capital. However, where A represents a much smaller portion of world GDP, the assumption of insignificant effect would be reasonably accurate. See supra note 87 and accompanying text. not 4 .

211. The efficiency loss on this somewhat smaller scale of operations would be about 3.5 , 
dent in $A$ will do as well as before since they have as much to supply and they can sell it globally at the same price as before. There is a clear welfare gain compared to $(I)$ : the increase $5.5 \mathrm{~W}$ dominates the decrease of $1 S E$ even priced by the new price ratio and even ignoring the reduction in payments that now have to be made to the widget industry suppliers of $K$.

\section{B. Effects in $B$}

1. Unchanged efficiency in manufacturing. Since $B$ 's required level of disclosure is not reduced, efficiency in its manufacturing sector stays the same as before. The same level of input would produce the same level of output. Thus entrepreneurs and labor in $B$ will not suffer any reduction in returns because of a loss of efficiency.

2. Decreased demand for stock exchange services. Issuers in $B$ take steps to facilitate the effecting of transactions in their shares in $A$ and so demand for $B$ 's stock exchange services decreases. $L$ is moved out of securities exchange services and into widgets to increase widget production. Purchasers of this increased production are residents of $A$ who take them in return for the securities exchange services they are exporting. Use as an example, a movement of labor sufficient to increase $W$ by 9 (so that total $W$ production $=109$ ) and decreases $S E$ by 10 (so that the total $S E$ production $=0$ ).

3. Elimination of rents for $\mathrm{Br}$. The supply of $\mathrm{Br}$ is fixed and so the disappearance of demand for $S E$ produced in $B$ will eliminate any return on $\mathrm{Br}$ in $\mathrm{B}$.

4. B's welfare decreases. The elimination of the rents for $\mathrm{Br}$ results in an overall decrease in the welfare of $B$ residents. In the example, total production is $109 \mathrm{~W}$ and no $S E$. $9 S E$ will be imported in return for $18 \mathrm{~W}$. Thus the suppliers of $L, B r$, and entrepreneurship are now able to consume $91 W$ and $9 S E$ less payments to capital, compared initially with $100 \mathrm{~W}$ and $10 S E$ less somewhat smaller payments to capital (reflecting the smaller widget industry in $B$ under the initial conditions) before $A$ lowers its requirements. Suppliers of $K$ resident in $B$ will do as well as before since they have just as much capital to supply and they can sell it globally at the same price as before. There is a clear welfare loss compared to (I): there is a loss in how much can be consumed of both $W$ and $S E$ 
even before accounting for the somewhat larger payments that now have to be made to $K$ suppliers due to the enlarged widget industry.

\section{A AND B Both Lower Their Required LeVels of DisClosure}

\section{A. Effects in $A$}

1. Reduced efficiency in manufacturing. The same as in (II) (i.e., in the example, a reduction of $4 W$ given the same level of inputs).

2. Demand for stock exchange services. Like in (I) but unlike (II), $A$ is not comparatively more attractive than $B$ and so demand for $A$ 's stock exchange services would be essentially the same as in (I) (assume a very low income elasticity of demand for $S E$ ). Thus $L$ in the widget industry is the same as initially in (I). In the example, total $W$ production $=96$ and $S E=10$.

\section{Price for $S E$ and rents for $B r$. Same as in (I).}

4. A's welfare decreases. There is a decrease in welfare not only compared to (II) but also compared to (I). Compared to (I) there is a decrease in efficiency in manufacturing and no increase in rents to $\mathrm{Br}$. In the example, total production would now be $96 \mathrm{~W}$ and $10 S E$. Exports of $S E$ and hence imports of $W$ will cease. Thus the suppliers of $\mathrm{L}, \mathrm{Br}$, and entrepreneurship are now able to consume $96 \mathrm{~W}$ plus $10 \mathrm{SE}$ less somewhat smaller payments to capital. Because of the assumption of constant returns to scale, the reduced payments to capital will be less than the decline in $W$. Suppliers of $K$ resident in $A$ will do as well as before since they have as much to supply and they can sell it globally at the same price as before. There is thus a clear welfare loss compared to (I): the decrease of $4 W$ dominates the decrease in the payments that now have to be made to suppliers of $K$ to the widget industry.

\section{B. Effects in $B$}

1. Reduced efficiency in manufacturing. Same as with $A$ in (III) since $B$ 's required level of disclosure is now also reduced.

2. Demand for stock exchange services. Compared to (II), demand for stock exchange services produced in $B$ has increased. 
Like in (I) but unlike in (II), $A$ is not comparatively more attractive than $B$ and so demand for $B$ 's stock exchange services would be essentially the same as in (I) (assume a very low income elasticity of demand for $S E$ ). Thus $L$ in the widget industry is the same as initially in (I). In the example, total $W$ production $=96$ and $S E=10$.

\section{Rents for Br. Same as in (I).}

4. B's welfare increases compared to (II) and decreases compared to $(I)$. There is an increase in welfare compared to (II) but a decrease compared to (I). Compared to (II) there is a decrease in efficiency in manufacturing but an increase in rents. In the example, total production would now be $96 \mathrm{~W}$ and $10 \mathrm{~L}$. Imports of $S E$ and hence exports of $W$ will cease. Thus the suppliers of $L, B r$, and entrepreneurship are now able to consume $96 \mathrm{~W}$ plus $10 S E$ less somewhat smaller payments to capital. Suppliers of $K$ resident in $B$ will do as well as before since they have as much and they can sell it globally at the same price as before. There is thus a clear welfare gain compared to (II): there is an increase of $4 \mathrm{~W}$ and an increase in $S E$ and a decrease in the payments that now have to be made to $K$ suppliers to the widget industry. The comparison between (III) and (I) is the same as for $A$.

\section{Prisoner's Dilemma Features}

If $B$ moved first, the analysis above would be exactly the same, but with the countries exchanging places. Absent cooperation, one of them is bound to move because reducing the strictness of its disclosure system will leave it better off, whatever the other party does. Thus such a reduction is the dominant strategy for each of them and a reduced disclosure level for both, despite its inferiority from a welfare point of view, is the dominant equilibrium.

We can construct a payoff matrix as follows. In the scenario described above, with $A$ moving first, the welfare positions of $A$ can be assigned ordinal utilities of 3,4 and 2 respectively for stages (I), (II), and (III). In the scenario with $B$ moving first, the welfare positions of $A$ can be assigned as 3,1 and 2 respectively for the equivalent stages. $B$ 's ordinal utility rankings in these two scenarios are just the reverse. In the scenario described above, with $A$ moving first, the welfare positions of $B$ can be assigned ordinal utilities of 3,1 , and 2 respectively for stages (I), (II), and (III). In the scenario with $B$ moving first, the welfare positions of $B$ can be assigned as 3,4 , and 2 respectively for the equivalent stages. 


\section{PAYOFF MATRIX}

B

\begin{tabular}{|c|c|c|}
\hline \multirow{3}{*}{ Strict } & Strict & Relaxed \\
\hline & 3,3 & 1,4 \\
\hline & 4,1 & 2,2 \\
\hline
\end{tabular}




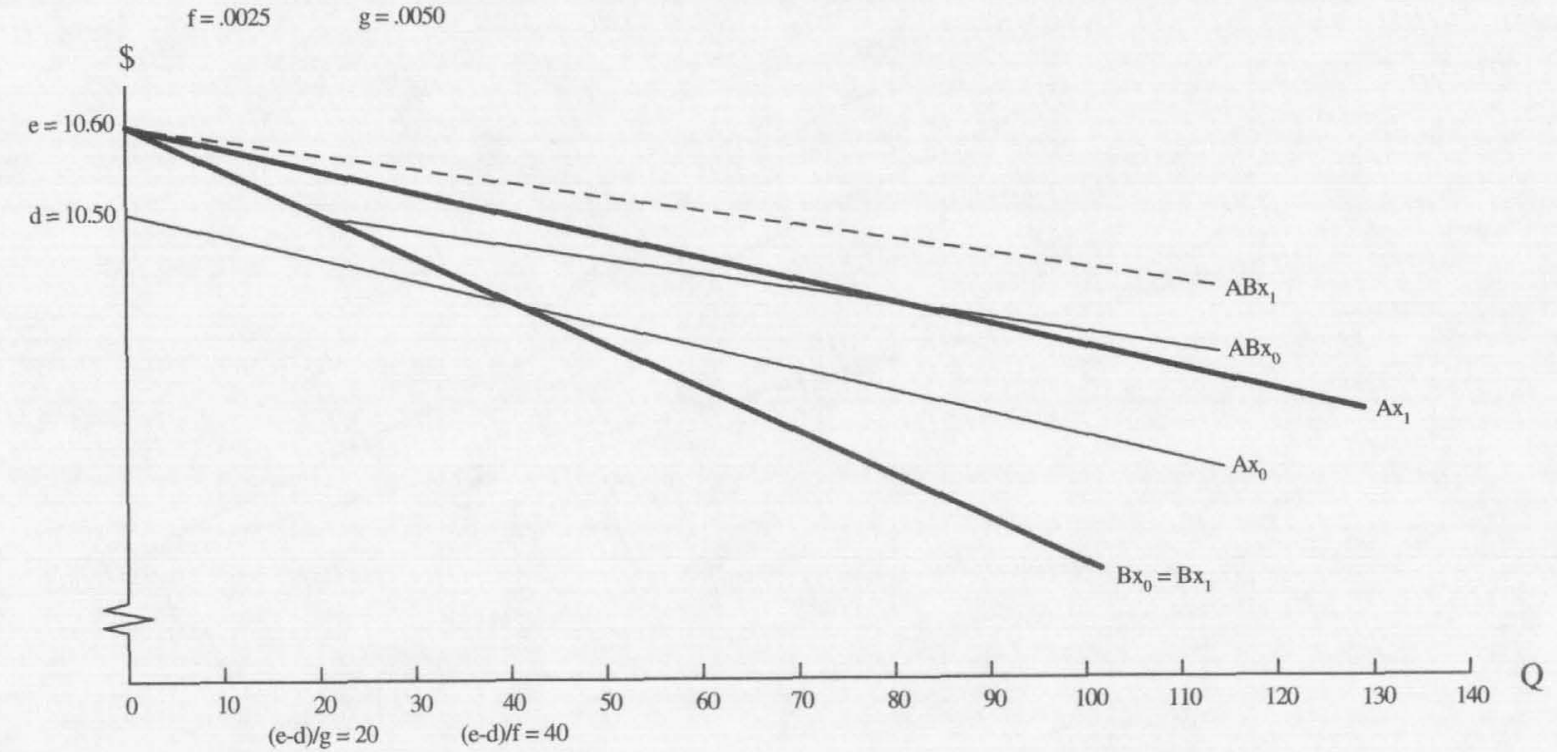




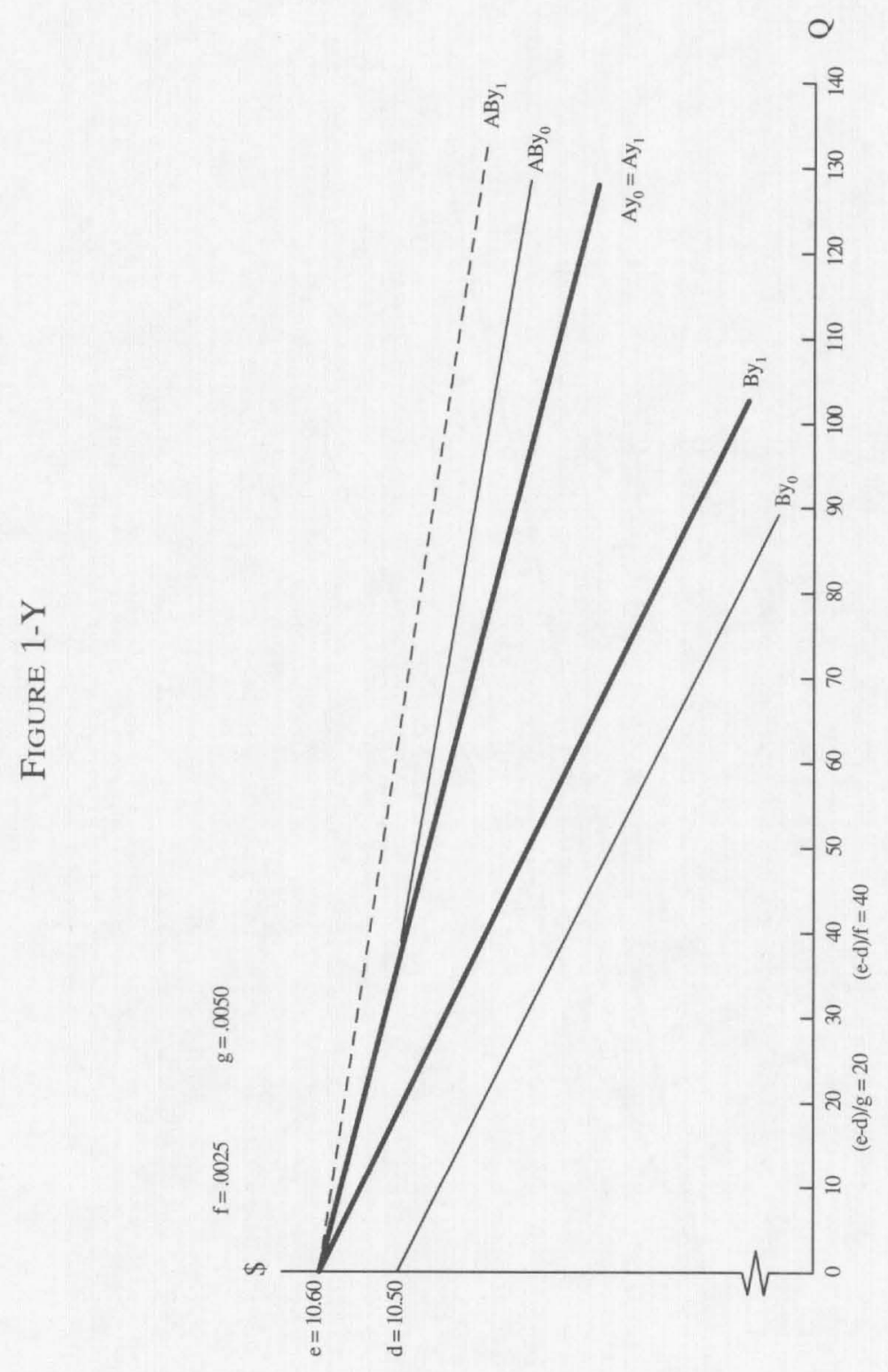

Reproduced with permission of the copyright owner. Further reproduction prohibited without permission. 